\title{
Long-Term Need for New Generating Capacity
}

March 1987

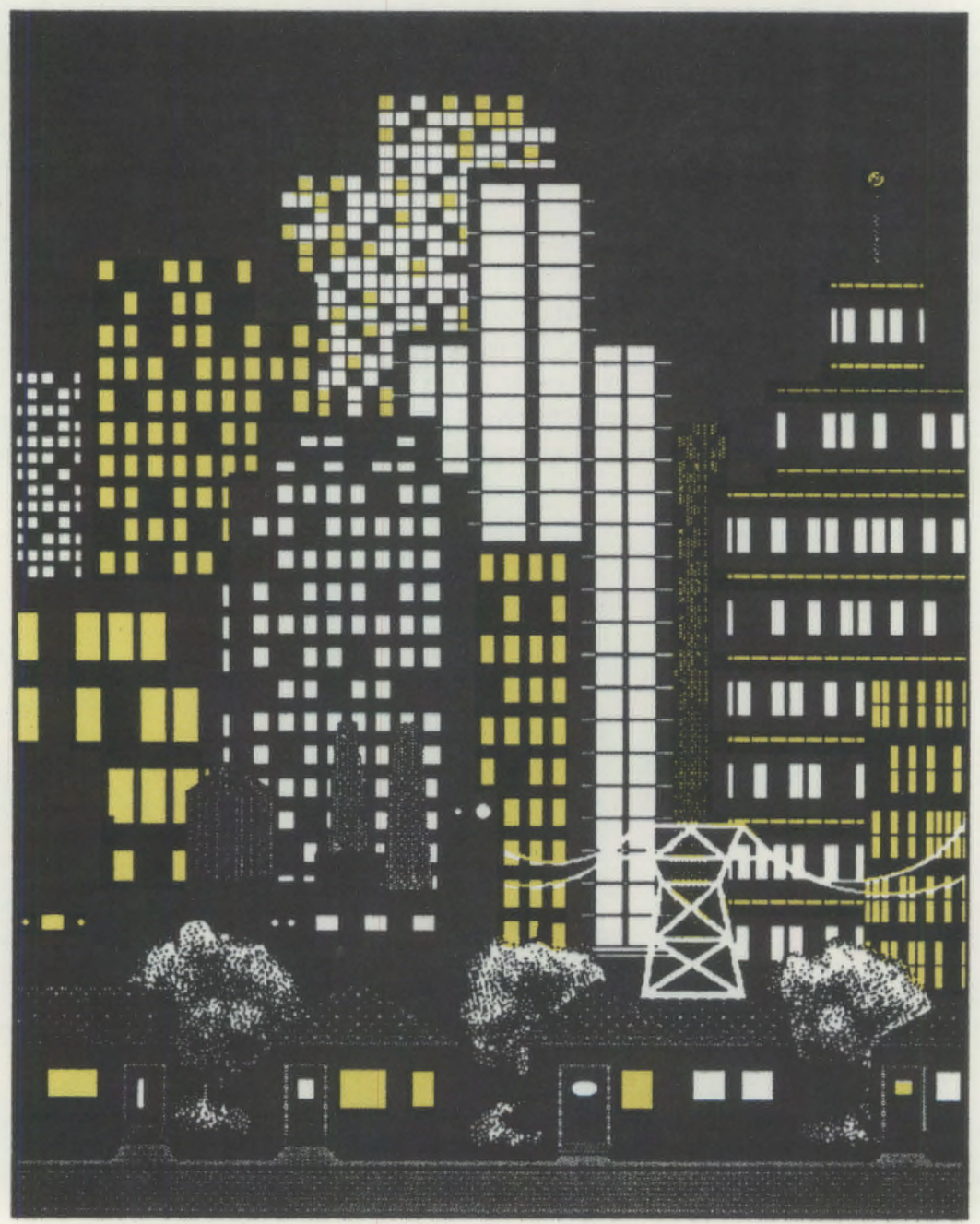

Prepared for the U.S. Department of Energy under Contract DE-AC06-76RLO 1830

Pacific Northwest Laboratory Operated for the U.S. Department of Energy by Battelle Memorial Institute 


\title{
DISCLAIMER
}

This report was prepared as an account of work sponsored by an agency of the United States Government. Neither the United States Government nor any agency thereof, nor Battelle Memorial Institute, nor any of their employees, makes any warranty, expressed or implied, or assumes any legal liability or responsibility for the accuracy, completeness, or usefulness of any information, apparatus, product, or process disclosed, or represents that its use would not infringe privately owned rights. Reference herein to any specific commercial product, process, or service by trade name, trademark, manufacturer, or otherwise, does not neçessarily constitute or imply its endorsement, recommendation, or favoring by the United States Government of any agency thereof, or Battelle Memorial Institute. The views and opinions of authors expressed herein do not necessarly state or reflect those of the United States Government or any agency thereof, or Battelle Memorial Institute.

\author{
PACIFIC NORTHWEST LABORATORY \\ operated by \\ BATTELLE MEMORIAL INSTITUTE \\ for the \\ UNITED STATES DEPARTMENT OF ENERGY \\ under Contract DE-AC06-76RLO 1830
}

\begin{tabular}{|c|c|}
\hline \multicolumn{2}{|c|}{ Printed in the United States of America } \\
\hline \multicolumn{2}{|c|}{$\begin{array}{l}\text { Available from } \\
\text { National Technical Information Service }\end{array}$} \\
\hline \multirow{3}{*}{\multicolumn{2}{|c|}{$\begin{array}{l}\text { United States Department of Commerce } \\
5285 \text { Port Royal Road } \\
\text { Springfield, Virginia } 22161\end{array}$}} \\
\hline & \\
\hline & \\
\hline \multirow{2}{*}{\multicolumn{2}{|c|}{$\begin{array}{l}\text { NTIS Price Codes } \\
\text { Microfiche A01 }\end{array}$}} \\
\hline & \\
\hline \multicolumn{2}{|c|}{ Printed Copy } \\
\hline & Price \\
\hline Pages & Codes \\
\hline $001-025$ & $\mathrm{~A} 02$ \\
\hline $026-050$ & A03 \\
\hline $051-075$ & $\mathrm{~A} 04$ \\
\hline $076-100$ & A05 \\
\hline $101-125$ & $A 06$ \\
\hline $126-150$ & $\mathrm{~A} 07$ \\
\hline $151-175$ & A08 \\
\hline $176-200$ & $A 09$ \\
\hline $201-225$ & $\mathrm{~A} 010$ \\
\hline $226-250$ & A011 \\
\hline $251-275$ & A012 \\
\hline $276-300$ & A013 \\
\hline
\end{tabular}


PNL -6193

UC $-80,5$

LONG-TERM NEED FOR

NEW GENERATING CAPACITY

C. H. Bloomster

E. T. Merrill

March 1987

Prepared for

the U.S. Department of Energy

under Contract DE-AC06-75RLO 1830

Pacific Northwest Laboratory

Richland, Washington 99352 



\section{ABSTRACT}

Electricity demand should continue to grow at about the same rate as GNP creating a need for large amounts of new generating capacity by the year 2000 . Bnly coat and nuclear at this time have the abundant domestic resources and assured technology to meet this need. However, large increase in both coal and nuclear usage will not be acceptable to society without solutions to many of the problems that now deter their increased usage. For coal the problems center around the safety and environmental impacts of increased coal mining and coal combustion. For nuclear the problems center around reactor safety, radioactive waste disposal, financial risk, and nuclear materials safeguards. The fuel requirements and waste generation for coal plants are orders of magnitude greater than for nuclear. Technology improvements and waste management practices must be pursued to mitigate environmental and safety impacts from electricity generation. 

LONG-TERM NEED FOR NEW GENERATING CAPACITY

\section{EXECUTIVE SUMMARY}

Obsolete generating capacity and the growing demand for electricity is placing this nation closer to an energy crisis. New baseload capacity, beyond that already under construction, will be needed in large amounts between 1992 and 2005 (recent trends point to the late 1990s) to meet projected electricity demand.

Currently, generating capacity is in surplus, but new power plant completions are projected to fall below 4 GW per year in 1990--a 40-year low (nuclear completions will fall to zero). The national long-term growth rate is projected to be near $2.5 \%$ per year--a growth rate that will generate a cumulative need for 1100 Gw on new baseload capacity by the year 2035 (Table S.1). A rapid recovery from this low point is needed, with new plant completions reaching 30 Gw per year by the year 2000 (give or take a few years depending on electricity demand). Orders for new capacity should start by 1990, given the lead time required for new baseload construction.

Only the coal and nuclear options have the abundant domestic resources and assured technology at this time to meet this need. 0 il and gas probably have sufficient resources, but they are expected to be more costly and more valuable for uses other than baseload generation. Other electricity generation technologies either do not have sufficient resources or require technological breakthroughs to become competitive on a large scale.

The need for new baseload capacity could be entirely met by either coal or nuclear. The required growth rates for either option are low; the capacity

TABLE S.1. Future Need for New Baseload Capacity

$\begin{array}{lccc}\text { Cumulative Need, Gw } & \frac{2005}{190} & \frac{2015}{490} & \frac{2035}{1100} \\ \text { Probable Bounds, Gw } & 10-400 & 150-800 & 600-2000\end{array}$


of the individual steps in either the coal or nuclear fuel cycles should b? expandable as needed without encountering supply constraints. The long leaj time step (8 to 10 years) in the coal fuel cycle is the expansion of mine spacity. The long lead time steps in the nuclear fuel cycle are the addition af enrichment capacity (6 to 8 years) and the expansion of mine capacity ( 8 to 10 years). Since the lead times for these steps are about the same as the 'ead time for power plant deployment, sufficient time for orderly expansion should be available. United States enrichment capacity and uranium mining capacity are currently in surplus, but under scenarios of high nuclear growth and import restrictions new capacity would be required in 20 to 30 years.

Although coal could replace existing nuclear plants over a period of years, an immediate shutdown of existing nuclear capacity would lead to powar cutbacks and would severely disrupt the economies in several regions. Nuclear currently generates almost $20 \%$ of the electricity nationally, and up to $35 \%$ in some regions. Replacing existing nuclear electricity generation with coal would require a $30 \%$ increase in coal mining and transport, and subsequently lead to a large increase in emissions. The reserve margin would fall below $20 \%$ in five of the nine NERC regions. Thus, load restrictions entailing economic and social costs would probably be required in some regions.

The forces that drive the yrowing need for new yenerating capacity are the growing demand for electricity and the need to replace obsolete capacity. The long-term demand for electricity is driven by yrowth in population, economic growth, and the substitution of electricity for other energy sources; all of these are projected to increase during the time span of this study. There a over 500 GW of installed capacity at present; most of this will be replaced over the 50-year time span of this study. The need for new capacity to replice obsolete capacity is about $2 \mathrm{GW} /$ year today but should increase to over $20 \mathrm{GW}$, year by 2010 .

Electricity demand should continue to grow over the long-term because its usage is closely tied to economic activity. National policies encourage economic growth. From its beginning about 100 years ago, electricity has steadily penetrated the economy with new and diverse uses. Until 1973, electricity usage grew at twice the rate of gross national product (GNP). Since 1973, 
electricity usage and GNP have increased at about the same rate. The consensus of numerous forecasts is that electricity usage will grow at a rate between 1.5 and $3.5 \%$ per year, or about the same as GNP.

The decline in the growth rate of electricity usage since 1973 led to a current surplus of generating capacity. Capacity expansion plans, geared to higher historic growth rates, adapted too slowly to the new conditions even though many plants were cancelled and the construction schedules of others were stretched out. However, the surplus capacity should be gradualiy absorbed through growth, and shortages in some regions may develop in the early $1990 \mathrm{~s}$ unless new capacity is added.

As the demand for electricity continues to grow, the need for new power plants will become more evident than it is today. Coal and nuclear, which provide nearly three-fourths of current electricity generation, will be called on to meet most of the need for new capacity. However, large increases in both coal and nuclear usage will not be acceptable to society without solutions to many of the problems cited below. Given the long lead time for research and technology development, planning decisions must be undertaken now on R\&o proyrams needed to assure that acceptable technology will be availabie to meet the future needs. Solving these problems should be approached with a sense of urgency. Today's surplus will soon disappear. To follow will be demands for new "acceptable" generating technology on a large scale.

Despite their huge potential, both coal and nuclear plants face a number of problems that threaten their future. For coal, the problems center around the safety and envirommental impacts of increased coal mining and coal combustion. Notable issues are acid rain, the greenhouse effect, acceptable emission limits, occupational health and safety, mine reciamation, and acid mine drainage. For nuclear, the problems center around reactor safety, radioactive waste disposal, financial risk, and nuclear materials safeguards. Notable issues include liability limits, nuclear proliferation, spent fuel disposal, radiation exposure, licensing simplification, quality assurance, and construction costs and schedules. Resolution of these problems and others will require both technological improvements and institutional innovation to attain the vast energy potential of these resources. 
Changing conditions could limit coal production and usage and cause a rapid shift from coal to nuclear. These might include 1) new coal mining regulations related to health and safety, land usage, reclamation, and mine waste; 2) decreased reliability of supply caused by natural or man-made disasters, public opposition, legal actions, labor disputes and other factors; 3) cost increases in mining and rail transport; and 4) new regulations rela:ed to gaseous emissions and solid waste disposal. The much larger quantities $)^{*}$ fuel required on a continuing basis make coal plants more vulnerable to future supply disruptions and future cost increases than nuclear plants.

For reasons of national energy security, improving the viability of nuclear energy, as one of the two large options currently available, is vital to meeting future electricity growth. New orders for nuclear plants depend primarily on reducing the financial risks now associated with construction and rate-making, but other conditions are also important to the future viability of the nuclear option. These include resolution of the nuclear waste disposal issue, improvements in the licensing process, improvements in technology, increased public and political support, and improvements in the design, construction and operation of nuclear reactors.

The fuel consumption in a coal-fired power plant is roughly 100,000 timess greater than in a nuclear plant. That is, about 100,000 tons of coal are con-sumed for every ton of uranium to generate the same amount of electricity. Therefore, the transportation requirements to the power plant are also about 100,000 times greater for coal than for uranium. However, only about 20 tons of coal must be mined for every ton of uranium ore mined. Most of the uraniur ore remains as tailings at the mill site and much of the uranium concentrate shipped from the mills remains as tailings at the enrichment plant. Typical yearly fuel cycle requirements and waste generation for a 1000 -M ple power plan: are summarized in Tabie S.2.

Coal-fired power plants with scrubbers produce about 12,000 times as much solid waste on a weight basis as nuclear plants for the same power output. A small fraction of the fly ash and scrubber sludge is used as by-products, but the majority is buried in landfills. Although coal plants yenerate much 
TABLE S.2. Annual Fuel Cycie Requirements, Electricity Generation, and Waste Generation per 1000 Mthe (1 GW) Capacity

Mining, tons mined

Mine and Mill Waste

(cubic yards)

Mine Shipments (tons)

Uranium Enrichment

(millions of separative

work units)

Fuel Fabrication

(equivalent number of PWR

fuel assemblies)

Eiectricity Generation (TWh) (a)

Fuel Consumption by Weight

(tons coal or uranium)

Nonradioactive Waste

(cubic yards)

Low-Level Radioactive Waste

(cubic yards)

High-Level Radioactive Waste (cubic yards)

Gaseous Emissions (tons)

$$
\begin{aligned}
& \mathrm{SO}_{2}(\mathrm{c}) \\
& \mathrm{NO}_{\mathrm{X}}(\mathrm{c}) \\
& \mathrm{CO}_{2} \\
& \mathrm{~F}
\end{aligned}
$$

$$
\begin{array}{cc}
\frac{\text { Coal }}{2,900,000} & \frac{\text { Nuclear }}{170,000} \\
390,000 & 120,000
\end{array}
$$$$
2,500,000 \quad 210
$$$$
\text { None } \quad 0.10
$$

None

$\begin{array}{rr}6.1^{(b)} & 6.1(b) \\ 2,500,000 & 23 \\ 780,000 & 47 \\ 0 & 82 \\ 0 & 14 \\ & \\ & \\ 4,900 & 0 \\ 16,000 & 0 \\ 7,200,000 & 0 \\ 0 & 0.04\end{array}$

\footnotetext{
(a) $T$ Wh = one billion kWh.

(b) $70 \%$ capacity factor.

(c) Based on emission limits.
} 
greater quantities of waste than nuclear plants, comparatively low-cost teck nology is in place to meet existing disposal regulations. Therefore, solid kaste disposal should not deter increased coal usage under existing regulations.

Nearly all of the coal converts into gaseous products of combustion, predominately $\mathrm{CO}_{2}$. Although $\mathrm{CO}_{2}$ emissions are not presently regulated, atmispheric warming (the greenhouse effect) is a potential concern in the longterm. About 3 tons of $\mathrm{CO}_{2}$ are produced for every ton of coal burned. Coal conbustion also produces $\mathrm{SO}_{2}$ and $\mathrm{NO}_{x}$. $\mathrm{SO}_{2}$ and $\mathrm{NO}_{x}$ emissions are regulated iow, and more stringent regulations are a potential concern. In contrast, nuclea ${ }^{\text {- }}$ fission produces no $\mathrm{CO}_{2}$, no $\mathrm{SO}_{2}$, no $\mathrm{NO}_{x}$, and a negligible quantity of gaseoll: emissions. 


\section{ACKNOWLEDGMENT}

The authors gratefully acknowledge the study guidance and constructive reviews provided by Edward Mastal, Department of Energy, and Laurin Dodd, William Richmond, Jack Fletcher and Harold Harty, all of Pacific Northwest Laboratory. 

CONTENTS

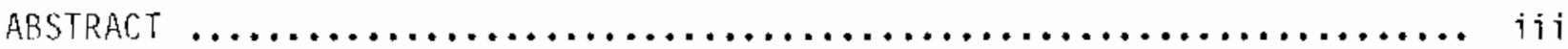

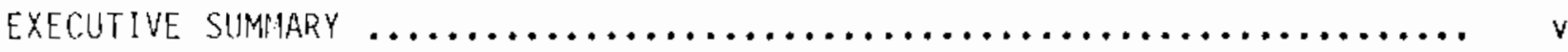

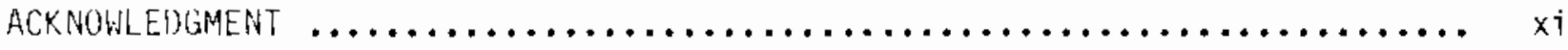

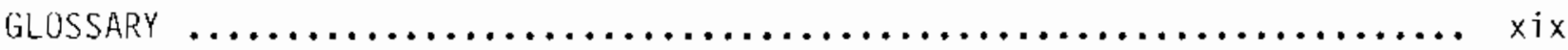

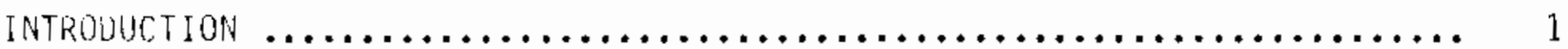

PROJECTIONS OF FLECTRICITY DEMAND $\ldots \ldots \ldots \ldots \ldots \ldots \ldots \ldots \ldots \ldots \ldots \ldots \ldots \ldots$

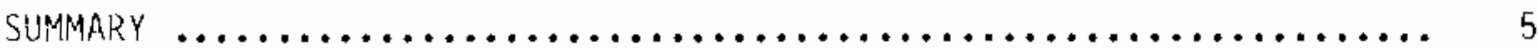

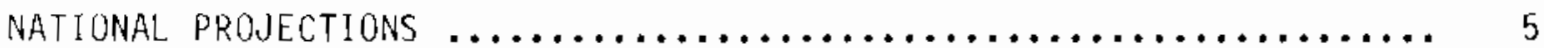

REGIONAL PROJECTIONS $\ldots \ldots \ldots \ldots \ldots \ldots \ldots \ldots \ldots \ldots \ldots \ldots \ldots \ldots \ldots \ldots$

IMPORTANCE OF LONG-TERM ANO NEAR-TERM PROJECTIONS $\ldots \ldots \ldots \ldots \ldots \ldots \ldots$

FACTORS AFFECTING ELECTRICITY DEMAND $\ldots \ldots \ldots \ldots \ldots \ldots \ldots \ldots \ldots \ldots \ldots \ldots \ldots \ldots$

PROJECTIONS OF THE NEEU FOR NEW GENERATING CAPACITY $\ldots \ldots \ldots \ldots \ldots \ldots \ldots \ldots .19$

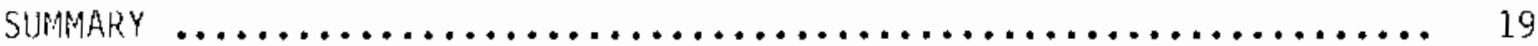

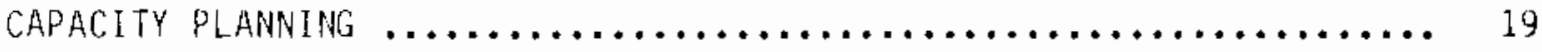

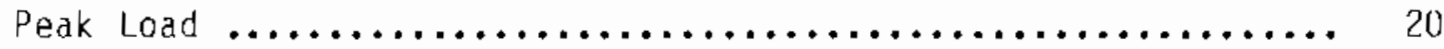

Reserve Margin $\ldots \ldots \ldots \ldots \ldots \ldots \ldots \ldots \ldots \ldots \ldots \ldots \ldots \ldots \ldots \ldots \ldots$

RETIREMENT OF OBSOLETE CAPACITY .................... 24

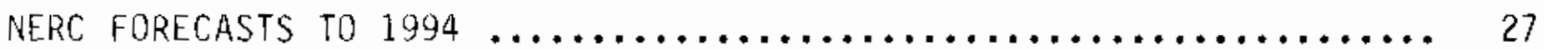

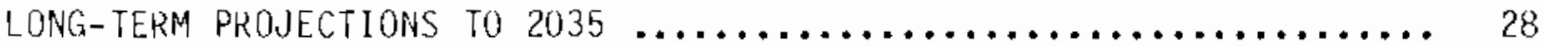

Scenarios for Estimating Long-Term Capacity Needs ........... 28

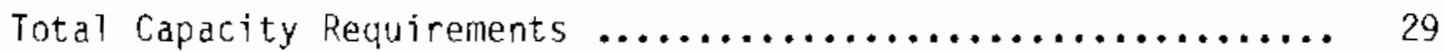

ANNUAL REQUIREMENTS FOR NEW CAPACITY $\ldots \ldots \ldots \ldots \ldots \ldots \ldots \ldots \ldots \ldots \ldots \ldots \ldots \ldots$

Regional Capacity Needs .......................... 34

Planning Uncertainties $\ldots \ldots \ldots \ldots \ldots \ldots \ldots \ldots \ldots \ldots \ldots \ldots \ldots \ldots$ 


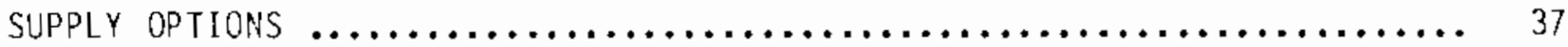

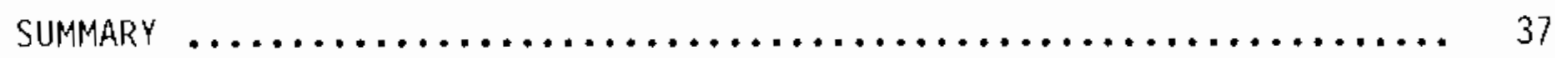

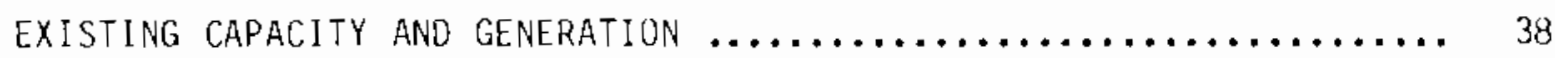

FUTURE SUPPLY OPTIONS $\ldots \ldots \ldots \ldots \ldots \ldots \ldots \ldots \ldots \ldots \ldots \ldots \ldots \ldots \ldots \ldots \ldots, 41$

RESOURCE CONSUMPTION AND WASTE PRODUCT GENERATION $\ldots \ldots \ldots \ldots \ldots \ldots \ldots \ldots$. 43

SUMMARY $\ldots \ldots \ldots \ldots \ldots \ldots \ldots \ldots \ldots \ldots \ldots \ldots \ldots \ldots \ldots \ldots \ldots, 43$

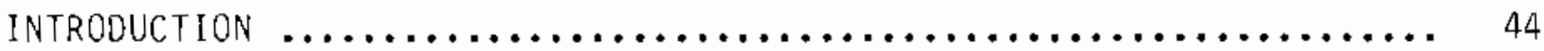

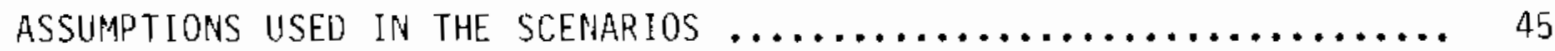

DESCRIPTION OF COAL AND NUCLEAR FUEL CYCLES $\ldots \ldots \ldots \ldots \ldots \ldots \ldots \ldots . \ldots . \ldots . \ldots$

Coal Fuel Cycle $\ldots \ldots \ldots \ldots \ldots \ldots \ldots \ldots \ldots \ldots \ldots \ldots \ldots \ldots \ldots, 46$

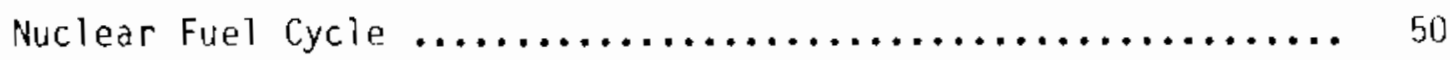

COMPARISON OF THE COAL AND URANIUM FUEL CYCLES $\ldots \ldots \ldots \ldots \ldots \ldots \ldots . \ldots . \ldots \ldots$

ANNUAL FUEL CYCLE REQUIREMENTS AND WASTE GENERATION FOR

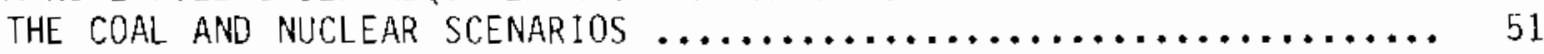

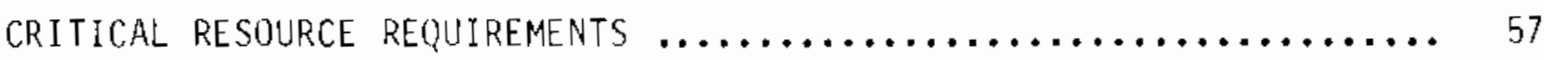

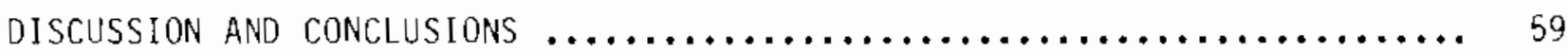

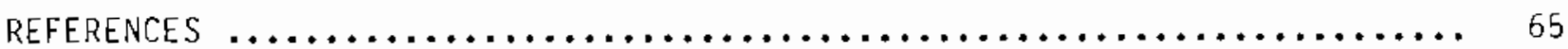

APPENDIX A - PROJECTIONS OF ELECTRICITY DEMAND $\ldots \ldots \ldots \ldots \ldots \ldots \ldots \ldots \ldots . . .1$

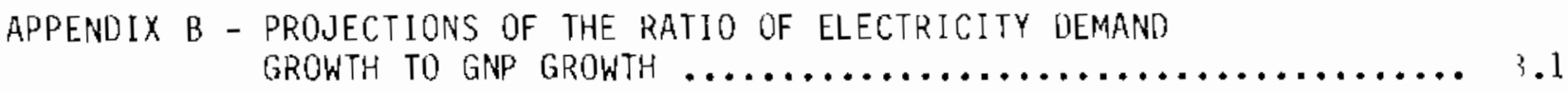

$\begin{aligned} \text { APPENDIX } C & - \text { COMPARISON OF EIA AND NERC CAPACITY AND } \\ & \text { ELECTRICITY GENERATION INFORMATION } \ldots \ldots \ldots \ldots \ldots \ldots \ldots \ldots \ldots . . . \ldots\end{aligned}$

APPENDIX D - SUMMARY OF EXISTING U.S. POWER PLANTS $\ldots \ldots \ldots \ldots \ldots \ldots \ldots \ldots$ i.,

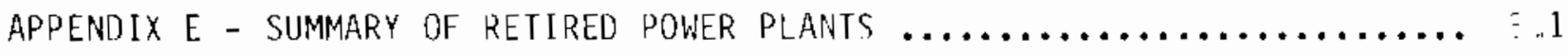

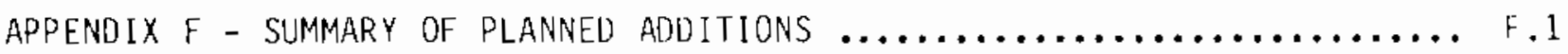

APPENDIX G - ANNUAL WASTE GENERATION AND FUEL CYCLE REQUIREMENTS

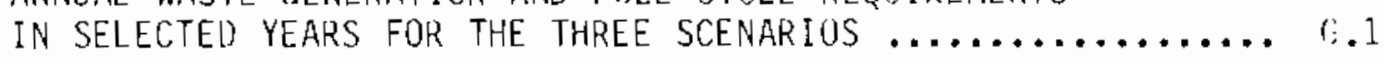


APPENDIX H APPENDIX I - HISTORICAL DATA: INSTALLED CAPACITY AND NET CAPACITY ADDITIONS ........................... I.1

APPENDIX J - PROJECTIONS OF PEAK DEMANDS, CAPACITY, AND ANNUAL ADDITIONS FOR THE THREE SCENARIOS $\ldots \ldots \ldots \ldots \ldots \ldots \ldots \ldots \ldots \ldots . . \ldots \ldots$ 


\section{FIGURES}

1 Projections of Electricity Demand $\ldots \ldots \ldots \ldots \ldots \ldots \ldots \ldots \ldots \ldots \ldots$

2 NERC Summer Peak Demand Projections--Comparison of Annual Ten-Year Forecasts for the United States ............... 10

3 Historic Growth of Electricity Demand and Generating Capacity ...... 12

4 Historic Electricity Prices in Constant 1972 vollars ............. 13

5 Electricity Use-Economic Measure Relationships by Economic

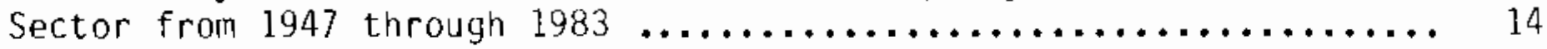

6 Historic Growth in Electricity Demand and Real GNP $\ldots \ldots \ldots \ldots \ldots$

7 Growth Rates of U.S. Electricity Use and GNP (a) and

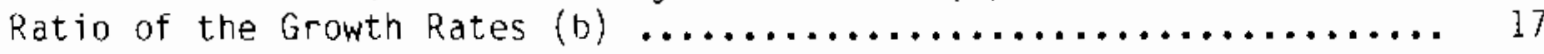

8 Annual National Variations in Peak Load and Energy Sales ......... 21

9 Relationship of Typical Load Duration Curve

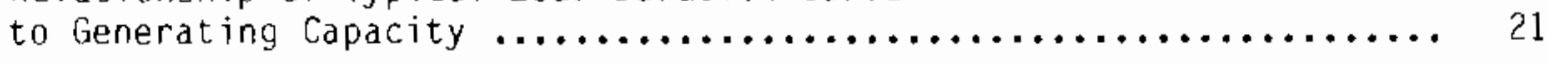

10 Hypothetical Examples Illustrating Extreme Diversity in Load Duration Curve ............................... 22

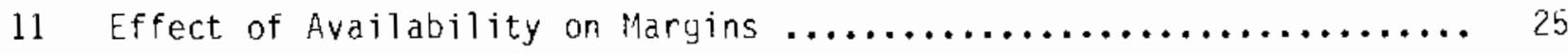

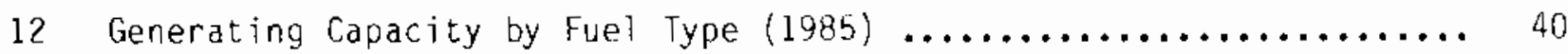

13 Electricity Generation by Fuel Type (1985) $\ldots \ldots \ldots \ldots \ldots \ldots \ldots \ldots \ldots$.......... 40

14 Equivalent Electricity Generation $\ldots \ldots \ldots \ldots \ldots \ldots \ldots \ldots \ldots \ldots \ldots \ldots \ldots \ldots \ldots \ldots \ldots$ 


\section{TABLES}

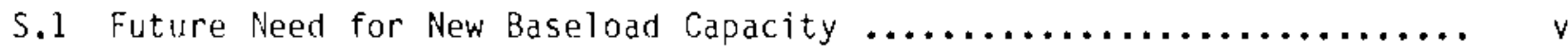

S.2 Annual Fuel Cycle Requirements, Electricity Generation, and Waste Generation per 1000 MWe (1 GW) Capacity ................. ix

1 Projected Regional Growth Rates in Electricity Demand and Peak Load .........................................

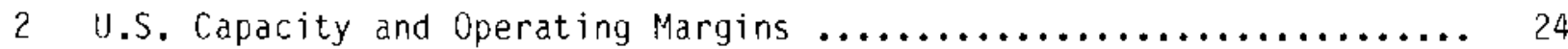

3 Variation in Capacity Retirements for Selected Service Life Assumptions .................................... 26

4 NERC Forecasts for Selected Years $\ldots \ldots \ldots \ldots \ldots \ldots \ldots \ldots \ldots \ldots \ldots \ldots \ldots . \ldots \ldots$

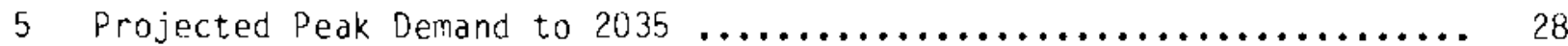

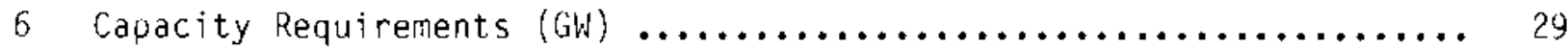

7 Year in which Currently Planned Capacity Required $\ldots \ldots \ldots \ldots \ldots \ldots . . . .30$

8 Incremental Capacity Requirements (GW) $\ldots \ldots \ldots \ldots \ldots \ldots \ldots \ldots \ldots \ldots$

9 Cumulative Retirement of 0bsolete Capacity (GW) $\ldots \ldots \ldots \ldots \ldots \ldots \ldots$

10 Cumulative Need for New Capacity (GW) for Both Load Growth and Replacement of Obsolete Capacity ....................... 31

11 Cumulative Need for New Baseload Capacity $(G W) \ldots \ldots \ldots \ldots \ldots \ldots \ldots . \ldots . \ldots 2$

12 Annual Additions to U.S. Generating Capacity (GW) ............... 33

13 Annual New Capacity Requirements $(G W) \ldots \ldots \ldots \ldots \ldots \ldots \ldots \ldots \ldots \ldots$

14 Annual Need for New Baseload Capacity (GW) in Selected Years ....... 35

15 Annual Need (MWe) for New Baseload Capacity by NERC Region for the Middle Demand Scenario .......................... 35

16 Power Generation by Type of Power Plant ...................... 39

17 Assumptions Used in Coal Fuel Cycle Analysis ................ 48

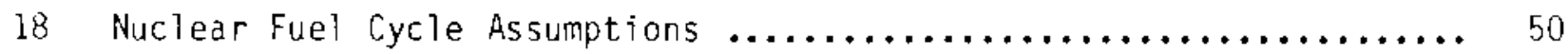

19 Comparison of Typical Coal and Uranium Fuel Cycle Requirements and Impacts to Produce 1 Billion kwh of Electricity 
20 Fuel Cycle Requirements, Electricity Generation, and waste

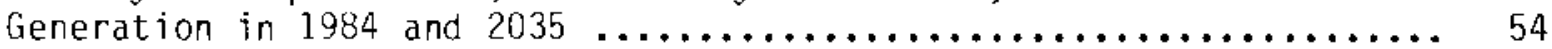

21 Per Capita Waste Generation and Resource Requirements ............ 56

A.1 Projections of Electricity Demand $\ldots \ldots \ldots \ldots \ldots \ldots \ldots \ldots \ldots \ldots \ldots \ldots \ldots$...

B.1 Projections of the Ratio of Electricity Demand Growth to

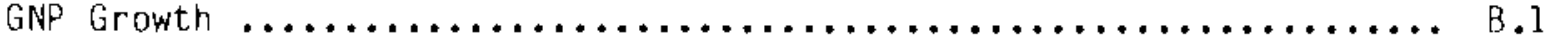

C.1 Comparison of EIA and NERC Reported Capacity and Generation ........ C.1

D.1 Existing U.S. Power Plants, $1985 \ldots \ldots \ldots \ldots \ldots \ldots \ldots \ldots \ldots \ldots \ldots \ldots \ldots \ldots .1$

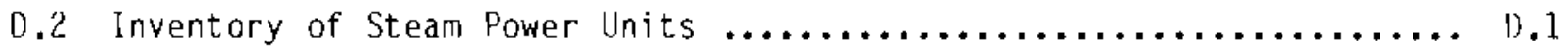

0.3 Inventory of Nuclear Power Units $\ldots \ldots \ldots \ldots \ldots \ldots \ldots \ldots \ldots \ldots \ldots \ldots . \ldots \ldots$

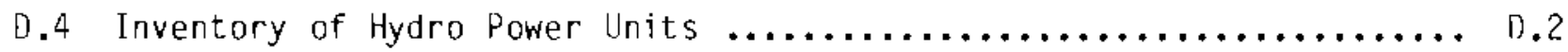

0.5 Inventory of Gas Turbine Power Units $\ldots \ldots \ldots \ldots \ldots \ldots \ldots \ldots \ldots \ldots \ldots$

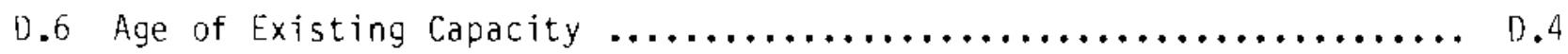

D.7 Regional Nuclear Capacity and Generation $\ldots \ldots \ldots \ldots \ldots \ldots \ldots \ldots \ldots \ldots$. .5

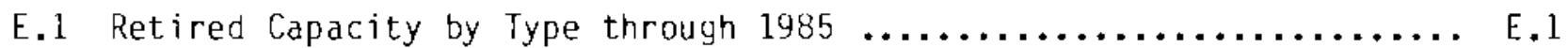

E.2 Retired Steam Capacity through $1985 \ldots \ldots \ldots \ldots \ldots \ldots \ldots \ldots \ldots \ldots \ldots \ldots \ldots$

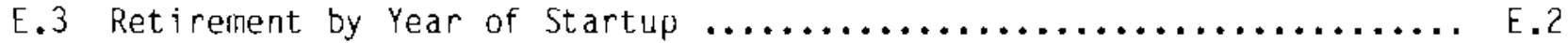

E.4 Retirement of Capacity by Time of Retirement $\ldots \ldots \ldots \ldots \ldots \ldots \ldots \ldots .2$

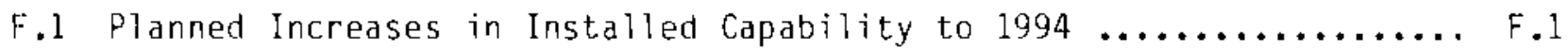

Q.1 Resource Requirements for Electricity Generation and Waste Products for the Three Scenarios .............................

I.1 Historical Data: Installed Capacity and Net Capacity

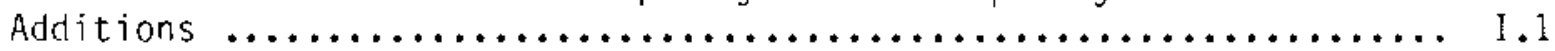

J.1 Projections (GW) for the High, Middle, and Low Demand Scenarios 


\section{GLOSSARY}

Baseload Capacity: The generating equipment normally operated to serve loads on an around-the-clock basis.

Boiling-Water Reactor (BWR): A light-water reactor in which water, used as both coolant and moderator, is allowed to boil in the reactor core. The resulting stean can be used directly to drive a turbine.

Capability: The maximum generating capacity available at a given instant of time, usually the summer peak. The capability is often less than the rated capacity because of deratings caused by high cooling water temperatures in the heat rejection system and other factors.

Capacity: The load for which a generating unit is rated, either by the user or by the manufacturer.

Capacity Factor: The ratio of the electricity produced by a generating unit, for the period of time considered, to the energy that could have been produced at continuous full-power operation during the same period.

Nameplate Capacity: The nominal electrical output of a generator, as specified by the manufacturer.

Elasticities of Vemand: The proportionate change in the quantity of energy demanded resulting from a proportionate change in price. The income elasticity of demand is defined similarly for changes in income. Elasticities are calculated as the ratio of the respective proportionate changes.

Generation (Electricity): The process of producing electric energy from other forms of energy; also, the amount of electric energy produced, expressed in watthours $($ Wh).

Gross Generation: The total amount of electric energy produced by generating units in a generating station or stations, measured at the generator terminals.

Net Generation: Gross generation less the electric energy consumed at the generating station for station use. (Energy required for pumping at pumped-storage plants is regarded as plant use and is subtracted from gross generation or from hydroelectric generation.)

Gigawatt (GW): One billion watts.

Gross National Product (GNP): A measure of the final output of goods and services by citizens of a country, whether living at home or in foreign countries. GNP comprises GDP and factor incomes from abroad accruing to residents, less the income earned in the domestic economy accruing to citizens of other countries. 
Intermediate or Load-following Capacity: Generating capacity that operates on an intermediate (between the baseload and peaking capacities) basis.

Kilowatt $(\mathrm{kW})$ : One thousand watts.

Kilowathour (kWh): One thousand watthours.

Light Water: Ordinary water $\left(\mathrm{H}_{2} \mathrm{O}\right)$, as distinguished form heavy water or deuterium oxide $\left(\mathrm{D}_{2} \mathrm{O}\right)$.

Light-Water Reactor (LWR): A nuclear reactor that uses water as the primary coolant and moderator, with slightly enriched uranium as fuel. There are two types of commercial light-water reactor-the boiling-water reactor (BWR) and the pressurized-water reactor (PWR).

Load Following: Regulation of the power output of electric generators within a prescribed area in response to changes in system frequency, tieline loading, or the relation of these to each other, so as to maintain the scheduled systen frequency and/or the established interchange with other areas within predetermined limits.

Megawatt (MW): One million watts.

Megawatthour (MWh): One million wathours.

NERC (North American Electric Reliability Council): An organization of the electric utility industry founded to promote the reliability of bulk power supply in the electric utility systems of North America.

Nuclear Power Plant: A single- or multi-unit facility in which heat produced in a reactor(s) by the fissioning of nuclear fuel is used to drive a steam turbine(s).

Nuclear Reactor: An apparatus in which the nuclear fission chain can be initiated, maintained, and controlled so that energy is released at a specific rate. The reactor apparatus includes fissionable material (fuel) such as uranium or plutonium; fertile material; moderating material (unless it is 1 fast reactor); a heavy-walled pressure vessel; shielding to protect personnit 1 ; provision for heat removal; and control elements and instrumentation.

Peaking Capacity: Generating capacity operated for short periods of time $1: 1$ meet peak demands on a daily or seasonal basis.

Peak Demand: In this report peak demand usually refers to the highest ann:il] national demand: This is the sum of the peak annual demands in each region, The regional peaks are non-coincident. There are daily peak demands and seasonal peak demands for which peaking capacity is required. 
Plutonium (Pu): A heavy, fissionable, radioactive, metallic element (atomic number 94). Plutonium occurs in nature in trace amounts. It can also be produced as a byproduct of the fission reaction in a uranium-field nuclear reactor and can be recovered for future use.

Pressurized-Water Reactor (PWR): A nuclear reactor in which heat is transferred from the core to a heat exchanger via water kept under high pressure, so that high temperatures can be maintained in the primary system without boiling the water. Steam is generated in a secondary circuit.

Reliability: The degree to which the performance of the elements of a bulk power electric system results in power being delivered to consumers within accepted standards and in the amount desired.

Reserve Margin: The installed capacity above the peak demand, defined as, (capacity less peak demand)/peak demand, and expressed in percent.

Separative Work Unit (SWU): A measure of the effort expended to separate a quantity of uranium of a given assay into two components, one having a higher percentage of uranium-235 and one having a lower percentage.

Summer Capability: The gross electrical output measured at the output terminals of the turbine generator(s) at the summer peak.

Terawathour (TWh): One trillion (10 12) watthours.

Uranium (U): A heavy, naturally radioactive, metallic element (atomic number 92). Its two principally occurring isotopes are uranium-235 and uranium-238. Uranium-235 is indispensable to the nuclear industry, because it is the only isotope existing in nature to any appreciable extent that is fissionable by thermal neutrons. Uranium-238 is also important, because it absorbs neutrons to produce a radioactive isotope that subsequently decays to plutonium-239, an isotope that also is fissionable by thermal neutrons. 



\section{INTRODUCTION}

Much controversy surrounds the future demand for electricity, the future need for large generating stations, and the future need for nuclear power. Generation capacity is currently in surplus in most regions. Construction of many large power plants, both coal and nuclear, has been cancelled in recent years. Yet the Senate recently held hearings (Senate 85) on the "potential for serious regional shortages of electric power... by the early 1990s." Such shortages could develop from an unanticipated increase in demand. At the present time, uncertainty in the size of the future demand for electricity is high. Price increases, conservation, and shifts in the economy have sharply reduced the growth rate in electrical demand from $7 \%$ per year prior to 1973 to $2.5 \%$ per year since 1973. This drop in growth rate, coupled with lengthening licensing and construction periods, have added to the uncertainties in planning capacity additions.

In this study, we examine the potential demand for electricity over the long-term to the year 2035. This 50 -year period was selected partiy because of the long time required to deploy new yenerating technology and partly to provide a sufficient time span in which to consider the impacts of retiring most of the current capacity. The objectives of this study are to 1) estimate the potential need for new baseload generating capacity; 2) evaluate some of the implications of meeting the need with coal plants only, with nuclear plants only, and with a combination of coal and nuclear plants; and 3) provide a perspective for long-terin research and development planning needs for developing improved technology and avoiding potential supply problems.

In 1986, electricity in the United States was generated mostly by coal $(56 \%)$, followed by nuclear (18\%), hydro (10\%), natural gas (11\%), petroleum $(4 \%)$, and other sources $(1 \%)$ (a) The generating capability at the summer peak was $636 \mathrm{GW}$. The suminer peak demand was $475 \mathrm{GW}$, and the reserve margin was $34 \%$.

The Worth American Electric Reliability Council (NERC) annually makes 10-year forecasts of electricity demand and capacity. In the period from 1986

(a) October 1986 forecast by NERC (NERC 86, p. 33). Final 1986 data not available at time of writing. 
to 1995 most of the new capacity installed will be coal and nuclear. Coal capacity is scheduled to increase $33 \mathrm{GW}$ from $272 \mathrm{GW}$ in 1985 to $305 \mathrm{GW}$ in 1335. Nuclear capacity is scheduled to increase $36 \mathrm{GW}$, from 71 to $107 \mathrm{GW}$. Hydro capacity is scheduled to remain about the same at $70 \mathrm{GW}$. Natural gas capazity is scheduled to drop $2 \mathrm{GW}$ to $42 \mathrm{GW}$. $0 i 1$ capacity is scheduled to drop $3 \mathrm{Gd}$ to $57 \mathrm{GW}$. Other types of capacity (geothermal, wind, solar, cogeneration, and biomass) is scheduled to increase from 3 to $18 \mathrm{GW}$. Dual (oil/gas) fuel casacity is scheduled to increase $2 \mathrm{GW}$ to $89 \mathrm{GW}$. Retirements of $12 \mathrm{GW}$ in the period to 1995 are planned; these are primarily small petroleum and natural gas units (NERC 86). The above capacities refer to the summer capability.

In this study, we treat electricity demand from a national standpoint because our primary concern is with the aggregate need for new capacity in the U.S. over the long term. Historically, the national electricity demand is strongly related to the gross national product, which is used as a predictor in most forecasts. Although utilities plan and add capacity on a regional basis, there is much commonality between regions in the supply options and in the economic factors that determine demand. The differences between regions in the supply options are primarily related to the transportation costs of fuel and the availability of indigenous alternative energy resources.

The primary focus in this study is the need for baseload generating capacity. Baseload capacity operates over extended periods of time without interruption. Load-following plants operate intermittently, usually cycling on a daily basis. Peaking plants operate for short periods of time, hours or minutes, during the peak loads. Baseload plants produce about $80 \%$ of the powar generated.

The base year for this study was 1984. At the time of initiation this was the latest year for which complete data were available. More recent data, nowever, is provided where available. Data for 1985 show an increase in elec. tricity demand of $2.2 \%$ over 1984 , and an increase in the summer peak deman 1 of $2.1 \%$ over 1984 (NERC 1986, pp. 10 and 15).

The remainder of this report is organized in five sections. The first section, Projections of Electricity Demand, analyzes recent long range projections and discusses the factors that affect electricity demand. The secon 1 
section, Projections of the Need for New Generating Capacity, estimates the long-term needs for new capacity under three scenarios. The third section, Supply Options, discusses the current electricity supply and summarizes future options. The fourth section, Resource Consumption and Waste Generation, compares coal and nuclear fuel cycles currently and under the three long-term scenarios. In the fifth section, Discussion and Conclusions, the implications of the data are presented. 


\section{PROJECTIONS OF ELECTRICITY DEMAND}

SUMMARY

The economic and social costs of inaccurate near-term electricity demand projections can be large because of the importance of electricity generation in our society. In retrospect, utility planning was inadequate to react accurately to the oil embargo in 1973 resulting in an installed national capacity base that now leads projected needs by about 4 years.

Current capacity expansion plans bring forecasted capacity in line with projected need in 1994. However, these plans are based on growth projections that tend to be low compared to most. This suggests the possibility of shortages within the next decade. Because of the assumed low growth rates now used for planning, the potential for new large excesses in capacity to emerge is low in the absence of a prolonged decline in demand.

Nearly all sources project electricity demand to grow at an annual rate between $1.5 \%$ and $3.5 \%$. Growth in electricity demand is closely tied to growth in the GNP. Projections of the ratio of growth in electricity demand to growth in the GNP range from $0.6 \%$ to $1.4 \%$ with an average of about unity.

NATIONAL PROJECTIONS

Numerous organizations project electricity demand (Appendix A). Nearly all of the recent projections fall within a range of growth rates varying from 1.5\% to $3.5 \%$ per year, using 1983 as a base year (Figure 1). On the low side are a few outliers that would require negative growth rates. On the high side are a few outliers that would require growth rates up to $4.5 \%$. These projections are used in this study to estimate the probable bounds for electricity demand in the near term and are extrapolated to estimate the bounds out to the year 2035 .

Most of the projections are derived from imputed relationships between electricity demand and economic activity. Gross national product and disposable income are measures of economic activity usually used to project electricity demand. Price elasticity, expressed as either real electricity prices or 


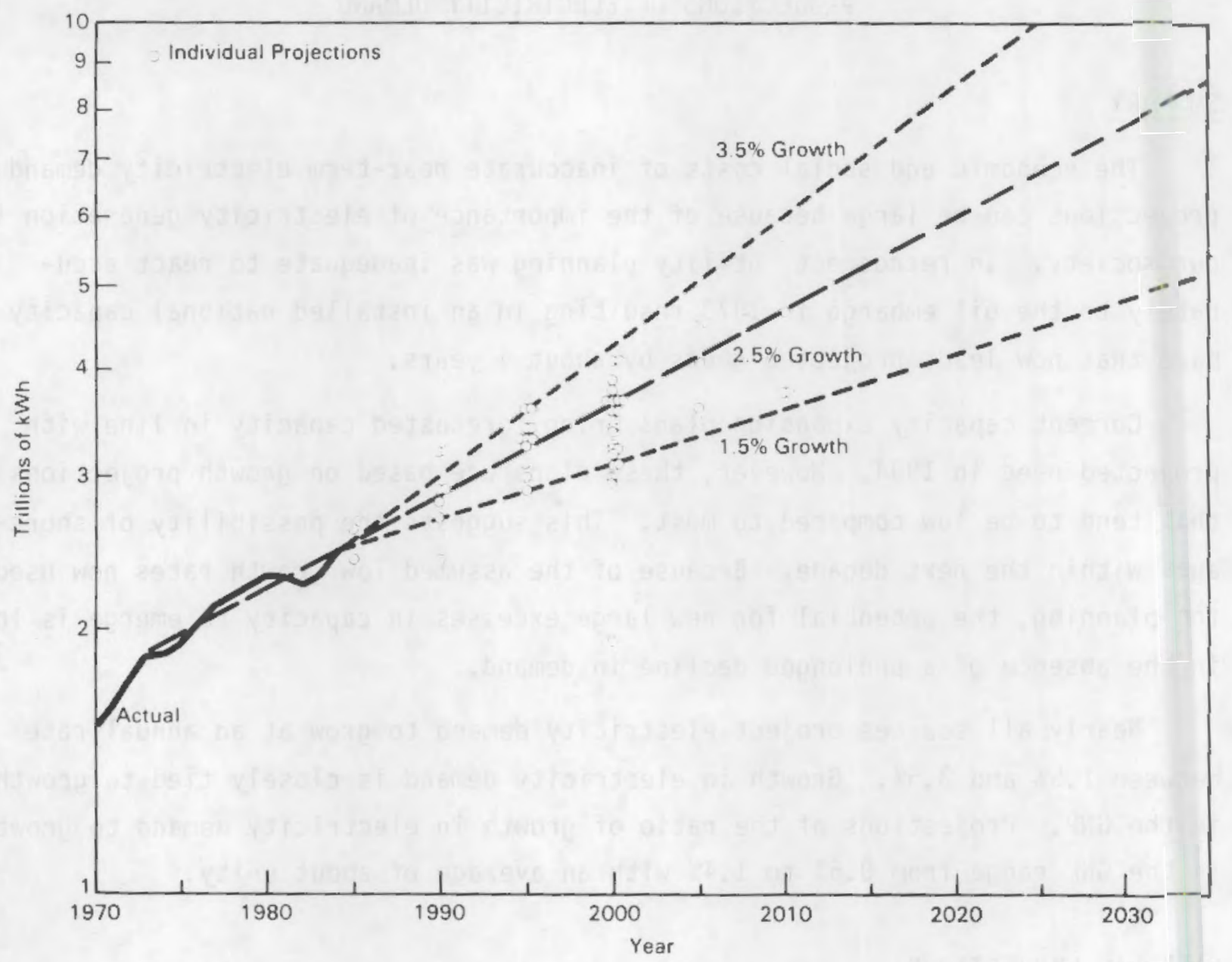

FIGURE 1. Projections of Electricity Demand

as the ratio of electricity prices to other energy prices, enters some econometric models on which projections are based. Some projections are simply based on historic trends, and others are based on per capita consumption. Forecasting methods gaining increased use are based on the end uses of electricity; these methods estimate changes in the consumption of electricity by specific consumers such as the aluminum industry or the residential sector. The end use forecasts are then aggregated (Senate 85, pp. 57-280; Hy 85, pp. 94-102; DOE 85, pp. 28-37; DOE 83; NRC 86; Se 85; OTA 84, pP. 29-41; DOE 84, pP. 5-28). 
REGIONAL PROJECTIONS

Different parts of the nation are expected to grow at different rates. Recent projections (NERC 85) of peak loads and electricity demand by NERC region are shown in Table 1. (a) Compare the projected annual growth rates in energy demand (the last four columns in Table 1). Note that the growth rates projected by three other forecasters (last three columns) are on average, higher than the NERC forecasts. Because of the slight difference in geographical boundaries, the forecasts are not exactly comparable. Since the NERC capacity projections reflect individual utility plans, this raises the possibility of regional and national energy shortages if the other forecasts are correct.

IMPORTANCE OF LONG-TERM AND NEAR-TERM PROJECTIONS

The economic and social costs of inaccurate projections(b) could be large because of the importance of electricity generation in our society. New baseload capacity, using existing coal or nuclear technology, now requires a lead time of 8 years or more for licensing and construction. The lead time from initial research and development to commercialization of a new generating technology can exceed 20 years.

Long-term projections of electricity supply needs are important to provide a basis for making business decisions by industries and utility organizations involved in energy supply as well as industrial consumers. In addition, they

(a) The NERC projections and planned capacity additions are an aggregation of individual utility system projections and plans.

(b) The ability to make accurate projections depends on the predictability of future events. In cases involving stable systems, as for example the solar system, long range predictions, such as eclipses, can be made with great accuracy. In systems involving human activities, the ability to predict future events is far more uncertain. The events surrounding the rise and fall in the price of petroleum over the last decade provide ample evidence. In many cases, long term economic projections are more accurate than short term forecasts since short term vagaries are eliminated. However, when dislocations occur in the long term trend, as occurred in 1973 for electricity demand, long term projections made prior to the dislocation can be far off. 
TABLE 1. Projected Regional Growth Rates in Electricity Demand and Peak Load

NERC Projections

\begin{tabular}{cccc} 
Peak Load & $\frac{\text { Energy Demand }}{\text { Annual }}$ & $\begin{array}{c}\text { Billions of Annual } \\
\text { Growth }\end{array}$ & $\frac{\mathrm{kWh}}{1984}$ \\
\hline
\end{tabular}

$\frac{\text { Other Projections }}{\text { Energy Demand }}$

\begin{tabular}{|c|c|c|c|c|c|c|c|c|c|}
\hline \multirow[b]{2}{*}{ NERC Regions (a) } & \multicolumn{2}{|c|}{ GW } & \multirow{2}{*}{$\begin{array}{l}\text { Growth } \\
\text { Rate, } \%\end{array}$} & \multicolumn{2}{|c|}{$\mathrm{kWh}$} & \multirow{2}{*}{$\begin{array}{l}\text { Growth } \\
\text { Rate, \% }\end{array}$} & \multicolumn{3}{|c|}{ (Annual Growth Rate, \%) } \\
\hline & 1984 & $19 \overline{94}$ & & 1984 & 1994 & & DOE (b) & DRI $(c)$ & Wharton(c) \\
\hline ECAR & 65.9 & 81.2 & 2.1 & 383 & 465 & 2.0 & 3.0 & 2.9 & 2.7 \\
\hline ERCOT & 36.9 & 52.4 & 3.6 & 185 & 267 & 3.7 & 3.6 & 2.7 & 3.2 \\
\hline MAAC & 35.4 & 39.3 & 1.1 & 186 & 220 & 1.7 & 3.1 & 2.9 & 3.0 \\
\hline MAIN & 35.2 & 40.5 & 1.4 & 171 & 207 & 1.9 & 3.0 & 2.9 & 2.7 \\
\hline MAPP-US & 20.7 & 26.5 & 2.5 & 105 & 136 & 2.6 & 2.6 & 2.0 & 2.1 \\
\hline NPCC-US & 38.1 & 45.5 & 1.8 & 217 & 256 & 1.7 & (d) & 3.2 & (d) \\
\hline SERC & 93.4 & 121.9 & 2.7 & 503 & 654 & 2.7 & 3.5 & 2.8 & (d) \\
\hline SPP & 45.6 & 59.4 & 2.7 & 226 & 288 & 2.5 & 3.6 & 2.7 & 3.2 \\
\hline WSCC & 80.0 & 100.1 & 2.3 & 469 & 588 & 2.3 & 3.5 & 3.5 & 2.6 \\
\hline NERC-US Total & 451.2 & 566.8 & 2.3 & 2446 & 3081 & 2.3 & 3.2 & 2.9 & 2.8 \\
\hline
\end{tabular}

SUBREGIONS

$\begin{array}{lllllllll}\text { New York (e) } & 21.9 & 25.1 & 1.4 & 124 & 141 & 1.3 & 2.1 \\ \text { New England (e) } & 16.3 & 20.4 & 2.4 & 93 & 115 & 2.1 & 2.3 \\ \text { TVA (f) } & 18.5 & 24.9 & 3.0 & 111 & 138 & 2.2 & 2.9 \\ \text { SERC<TVA(f) } & 74.9 & 97.0 & 2.6 & 391 & 516 & 2.8 & 3.9\end{array}$

(a) NERC Regions are shown in Appendix $\mathrm{H}$.

(b) Middle case to 1995.

(c) Senate $85, p p=125,151$.

(d) Projected by subregion below.

(e) Subregions of NPCC - US.

(f) Subregions of SERC. 
are necessary to plan and perform research and development activities necessary to yield a high probability that future needs can be met at low costs with minimum impact to the environment.

The absolute accuracy of long-term projections is not as important as for near-term projections assuming that projections are frequently updated and that energy supply strategies and associated R\&D programs are appropriately re-evaluated to reflect changes in projections. However, it must be recognized that if there is a large mismatch between long-term projections and realizations, then strategies developed for meeting long-term needs may not be appropriate. For example, over-prediction of electricity demand growth rates in the early 1970s led to supply strategies that would have led to an early introduction of both nuclear breeder reactors and recycling of uranium in light-water reactors (LWR). In the future, under-prediction of demand could similarly result in non-optimum supply strategies.

Accurate near-term projections are essential in order to avoid disruptions in economic and social activity that can be caused by either shortages of efficient generating capacity or by an excess capacity of capital-intensive plants.

Inaccurate near-term projections on the low side could result in suppliers having to utilize inefficient high cost power sources or in consumers experiencing power shortages. Inaccurate projections on the high side could result in over-building, and subsequent underutilization, of capital-intensive plants. As demonstrated in the recent past, over-building can threaten the financial viability of the utilities involved and can have a dramatic impact on rates charged to the consumers.

Assumptions about the future are necessary for today's business decisions and provide a basis for planning activities. Therefore, long-term projections are important, but not in an absolute sense since plans can be periodically revised. Long-range planning is required to efficiently meet projected demands at lowest cost, particularly taking into consideration the long lead time required for power plant construction and licensing. Further, the time from the initial R\&D work through the introduction and commercialization of a new generating technology can easily exceed 20 years. 
The electric utility industry through the NERC annually makes a 10-year forecast of peak demands (NERC 85 ). The inability of utility planning to react accurately to the oil embargo in 1973 and subsequent events is illustrated in the series of 10-year planning projections since 1974 (Figure 2). Each year NERC reduced the projected growth rate about $10 \%$ from the previous year. After 10 years, the peak load projections finally aligned with the post 1973 actual trend. An EPRI report summary concluded that "the overoptimism of the industry forecasts after 1974 was due to the unanticipated slowdown in the growth of the economy, the unexpected continuation of high electricity prices, and an underestimation of the full extent of load sensitivity to price" (EPRI 85).

Orders for new capacity were based on projections of peak load. As the projections of peak demand were gradually reduced, the utility systems adjusted through cancellations and stretch outs of construction projects. In 1984, the installed capacity was $604 \mathrm{GW}$, about 100 GW below the forecast peak demand made

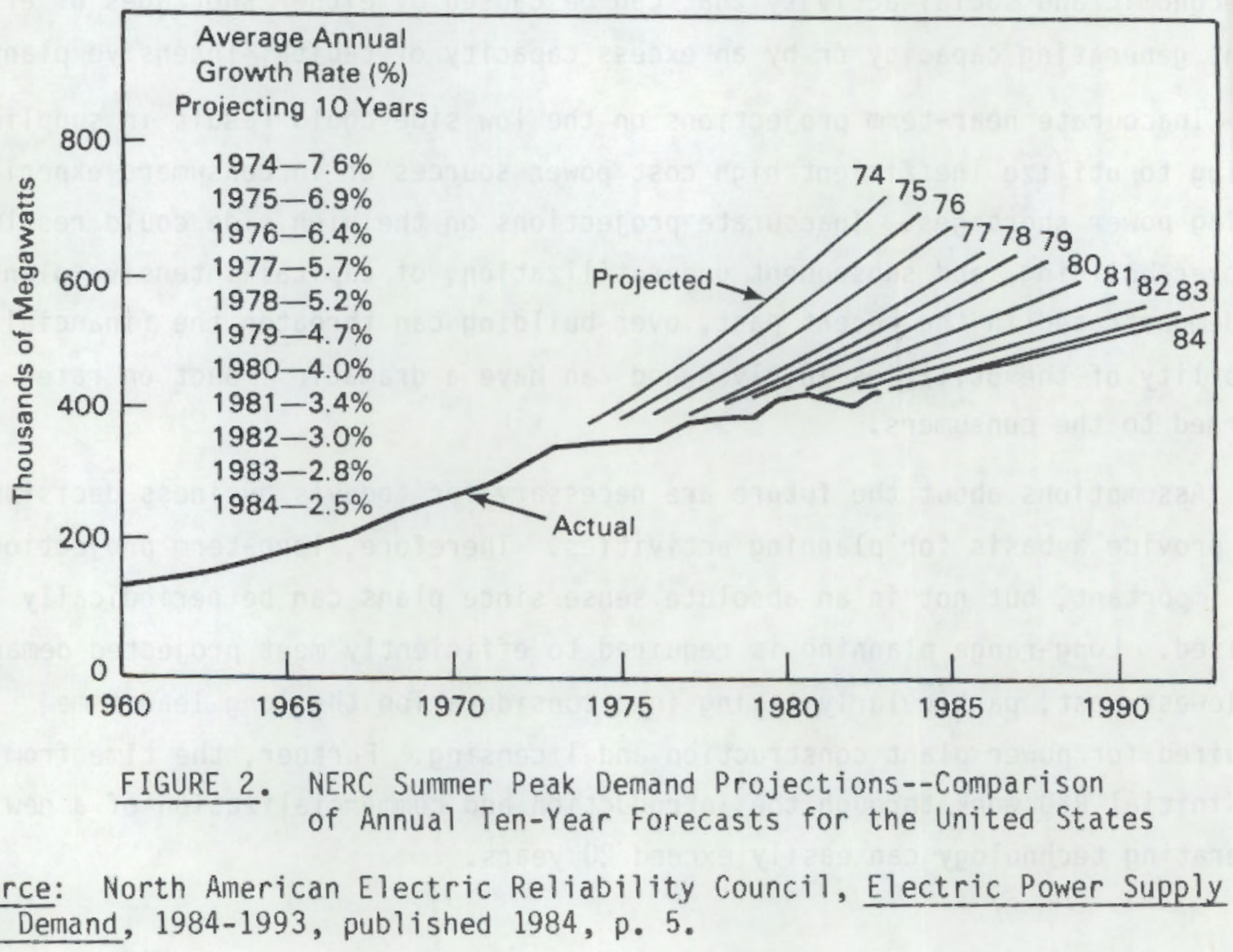


in 1974. The actual peak demand in 1984 was 451 GW, about 250 GW below the forecast made in 1974. The 1984 installed capacity was sufficient to meet 1988 peak load projections assuming a $2.5 \%$ growth rate and a $20 \%$ reserve margin. Thus, on a national basis, the surplus of installed generating capacity was about 4 years of capacity growth. Some regions are not in surplus, and, as discussed later, the appropriateness of a $20 \%$ reserve margin has been questioned. Also, $18 \%$ of the capacity was fueled by petroleum and $14 \%$ was fueled by natural gas. Past policies (e.g., Fuel Use Act, Public Law 95-620) generally discouraged use of these energy sources for electricity generation.

Unti) 1973, electricity demand grew rapidly (DOE 85a, pp. 60-61) and excesses in capacity, if any, could be worked off quickly. After 1973, demand slowed abruptly but capacity expansion did not (Figure 3). Excess capacity quickly developed and persists to this day. Capacity expansion plans have been revised downward bringing forecasted capacity in line with projected need by about 1994. This sets up a potential shortfall situation if demand increases abruptiy. On the other side, the potential for new large excesses in capacity to emerge is now low unless a prolonged decline in demand develops.

\section{FACTORS AFFECTING ELECTRICITY DEMAND}

One reason for the decline in growth rate since 1973 is the increase in real electricity prices (Figure 4). Prior to 1972 real electricity prices steadily declined. The residential price and the weighted average price for all classes are shown in Figure 4 (DOE 85a, pp. 60-61). The weighted average price for all classes of services is about $12 \%$ below the residential price. Steep increases in electricity prices followed the large increases in petroleum prices by the Organization of Petroleum Exporting Countries (OPEC). Over the short term price elasticity is relatively low $(-0.2)$ and electricity usage is little affected by price changes. However, over the long-term, price elasticity approaches unity and electricity usage responds inversely to price changes (Hy 85, p. 41).

Econometric studies link electricity demand to economic activity (real GNP and real disposable income, see Figure 5) and climate (heating and cooling degree days) in addition to price. Electricity demand and real GNP have grown 


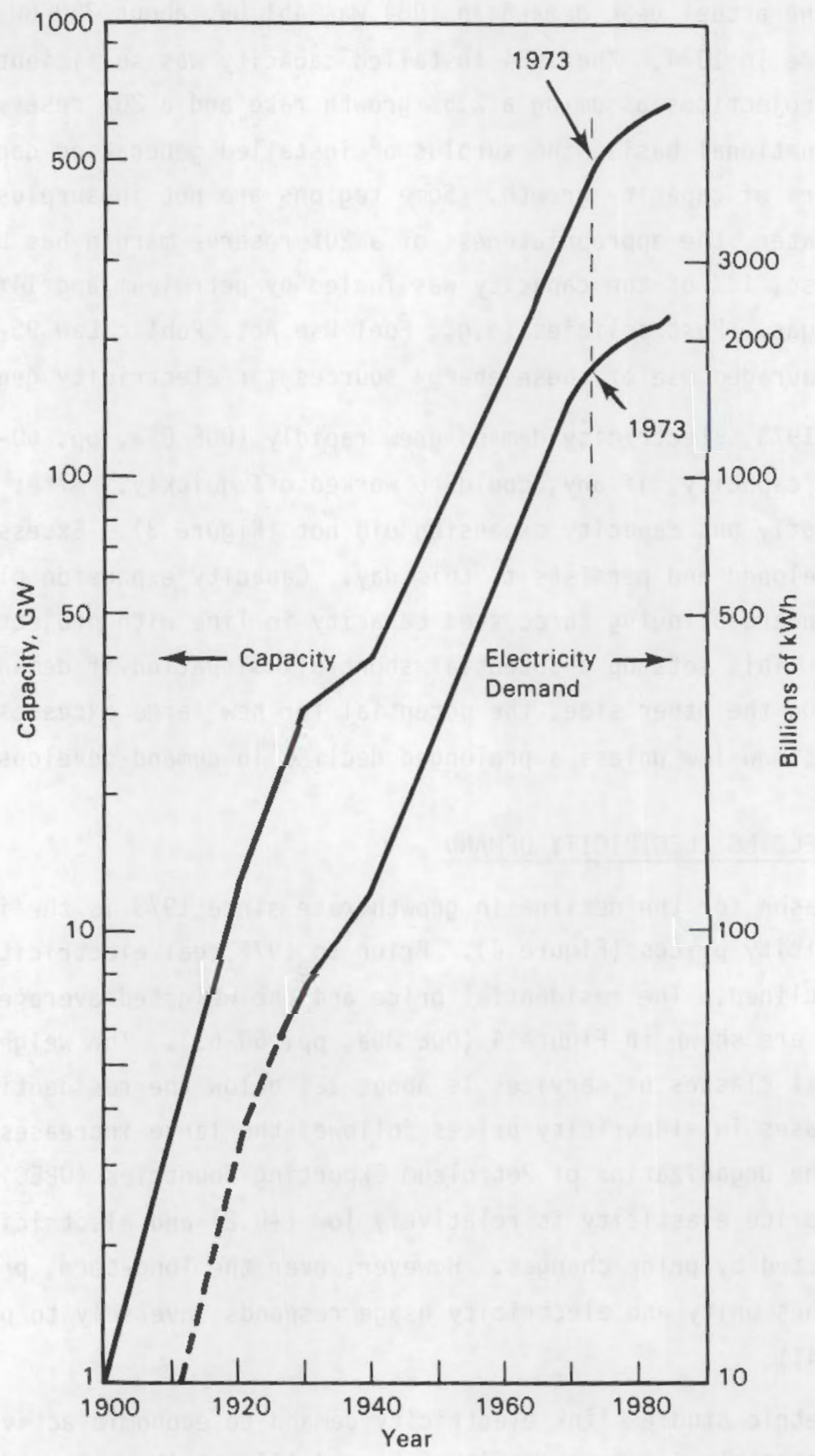

FIGURE 3. Historic Growth of Electricity Demand and Generating Capacity 


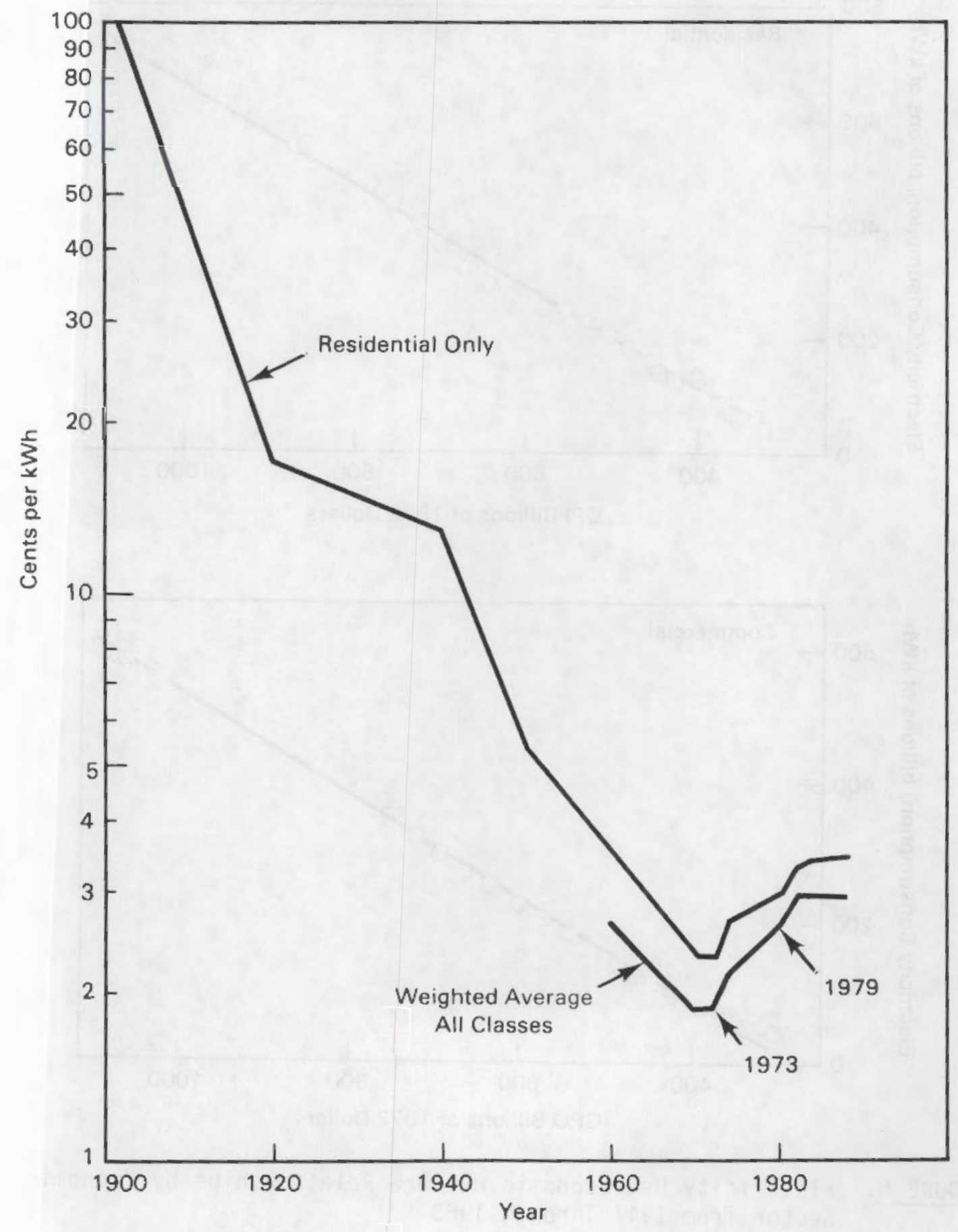

FIGURE 4. Historic Electricity Prices in Constant 1972 Dollars 

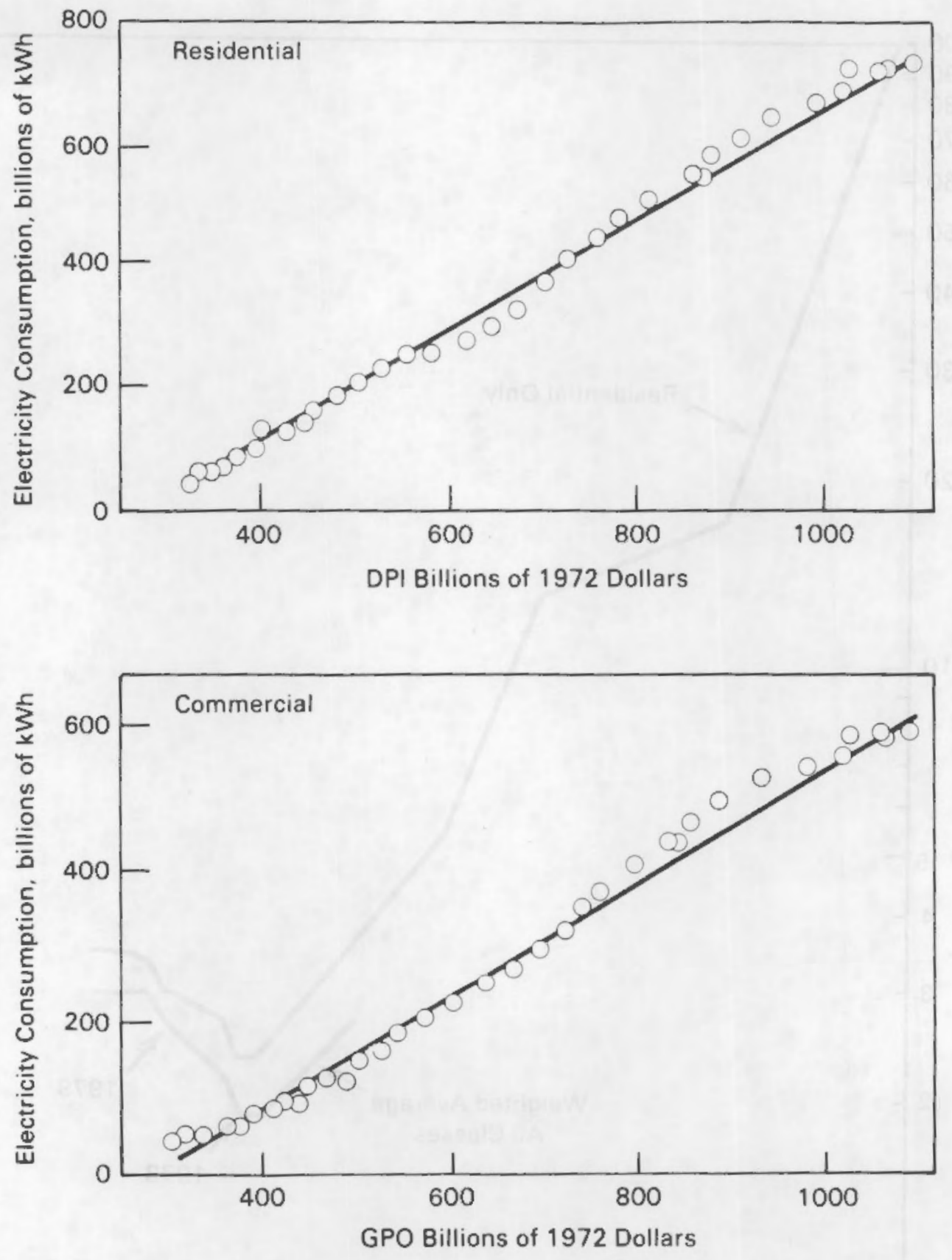

FIGURE 5. Electricity Use-Economic Measure Relationships by Economic Sector from 1947 Through 1983 


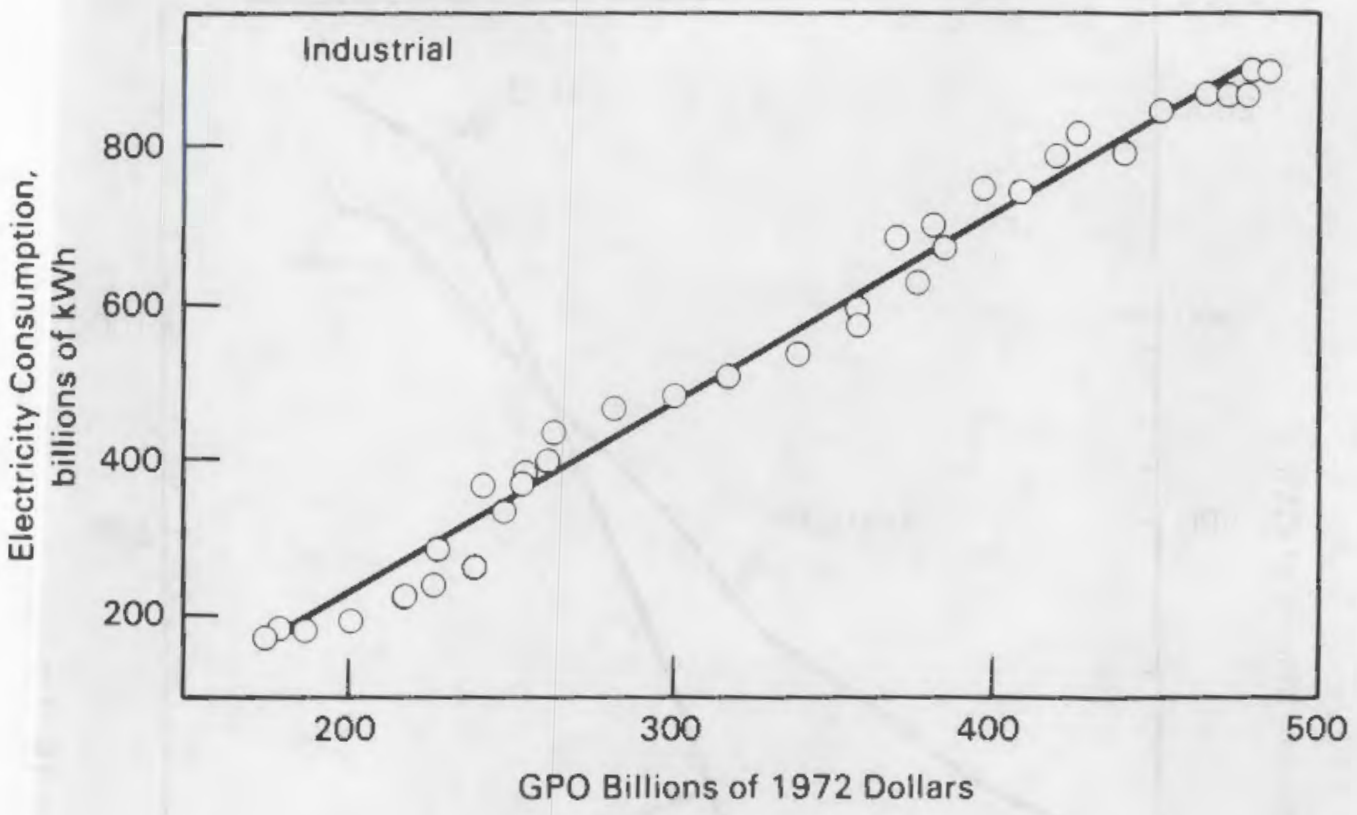

FIGURE 5. (contd)

Note: Different scales are used for the three sectors to highlight the Tinearity of the electricity use-economic output relationship within sectors. Based on data from Edison Electric Institute, Statistical Yearbook of the Electric Utility Industry, various issues; U.S. Department of Commerce, Bureau of Economic Analysis, The National Income and Product Accounts of the United States, 1929-76, Statistical Tables; and Survey of Current Business, various issues. Dollar values are shown for Disposable Personal Income (DPI) and Gross Product Originating (GPO).

Source: Compilation and figure by Energy Study Center, Electric Power Research Institute, Palo Alto, California. This figure is taken from NRC 86, p. 28.

consistently over time (Figure 6). The growth in electricity demand exceeds GNP growth by a factor of two through 1973. Since 1973, electricity growth generally matches GNP growth (Figure 7). Studies of the relationship between electricity demand and GNP show a positive correlation with an elasticity of 0.5 for the short run and 0.8 for the lang run (Hy 85, p. 44). Recent projections (Appendix B) of the ratio of electricity growth to real GNP growth range from 0.6 to 1.4. As noted earlier, many econometric models use forecasts of GNP to project electricity demand.

Weather strongly affects electricity demand (DOE 85b, pp. 18-20). Peak loads usually coincide with temperature extremes. Air conditioning, common in 


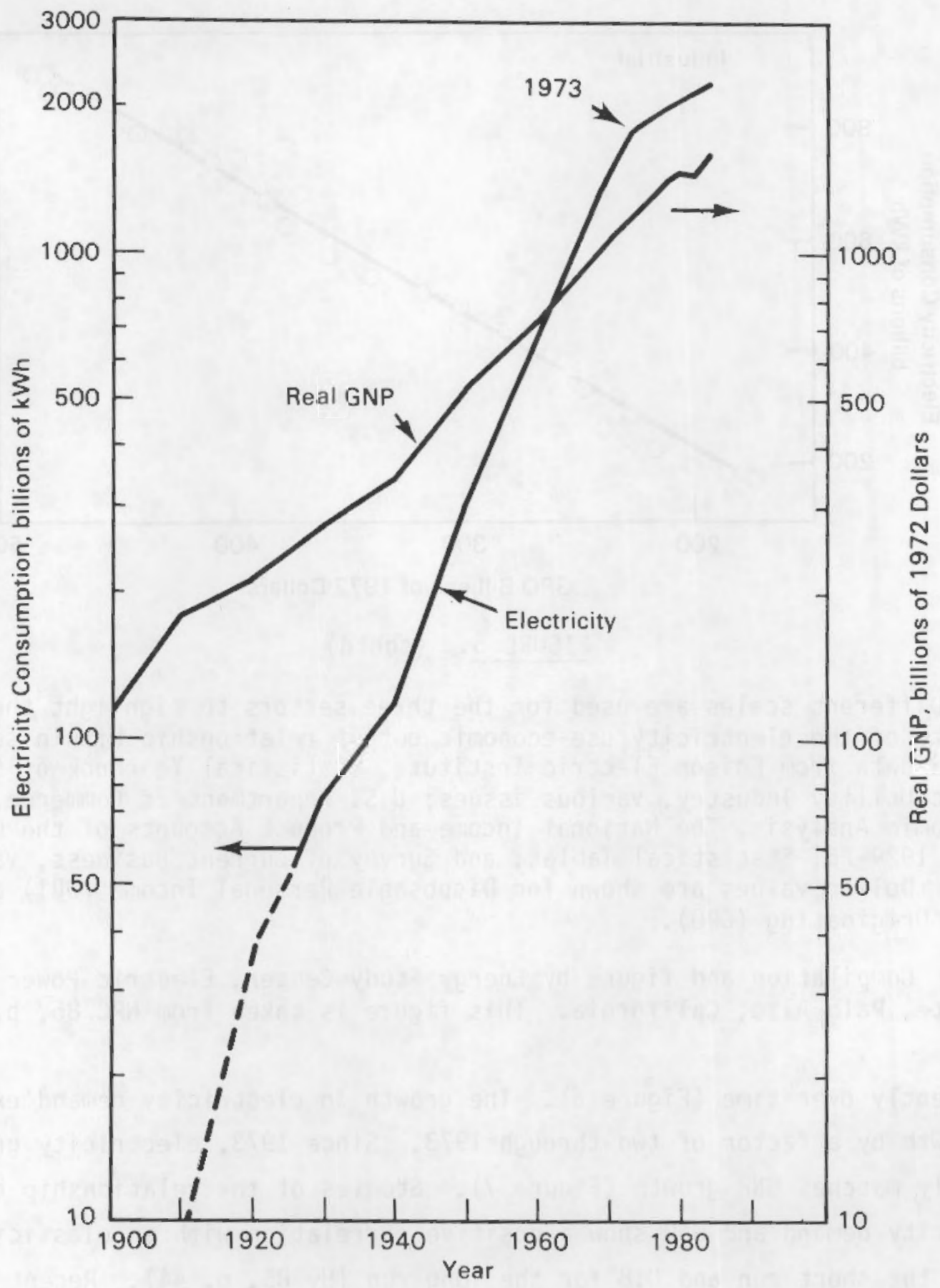

FIGURE 6. Historic Growth in Electricity Demand and Real GNP 


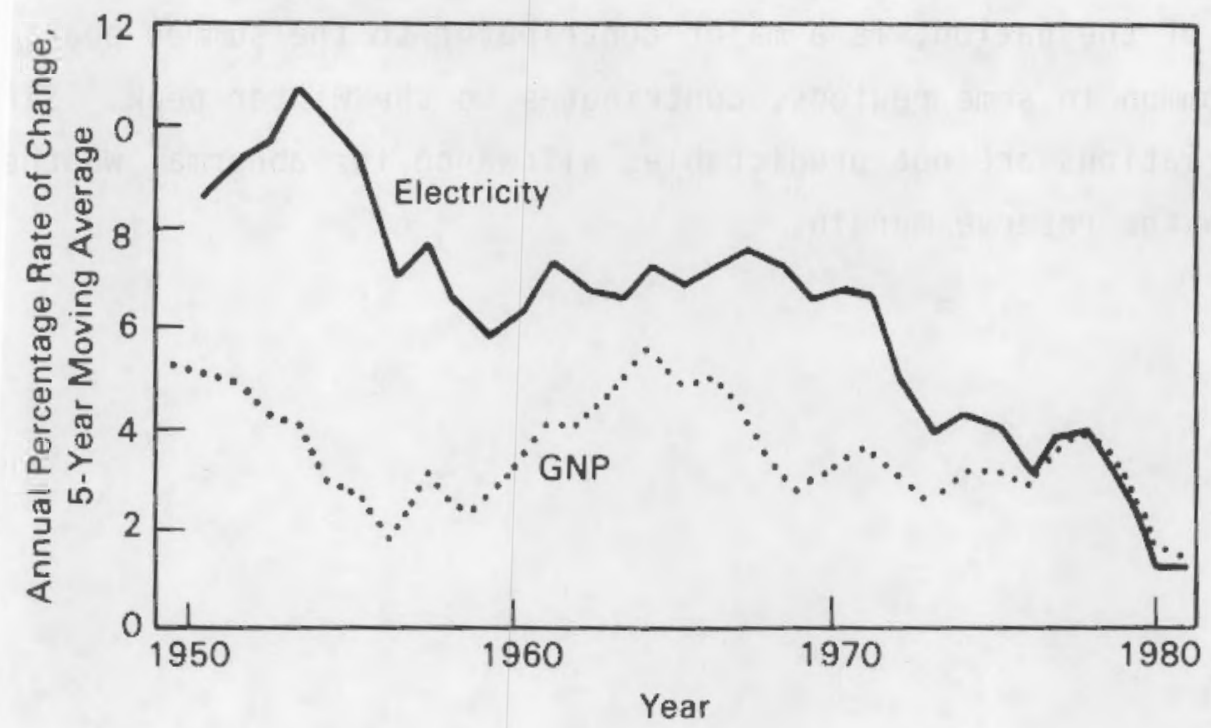

a)

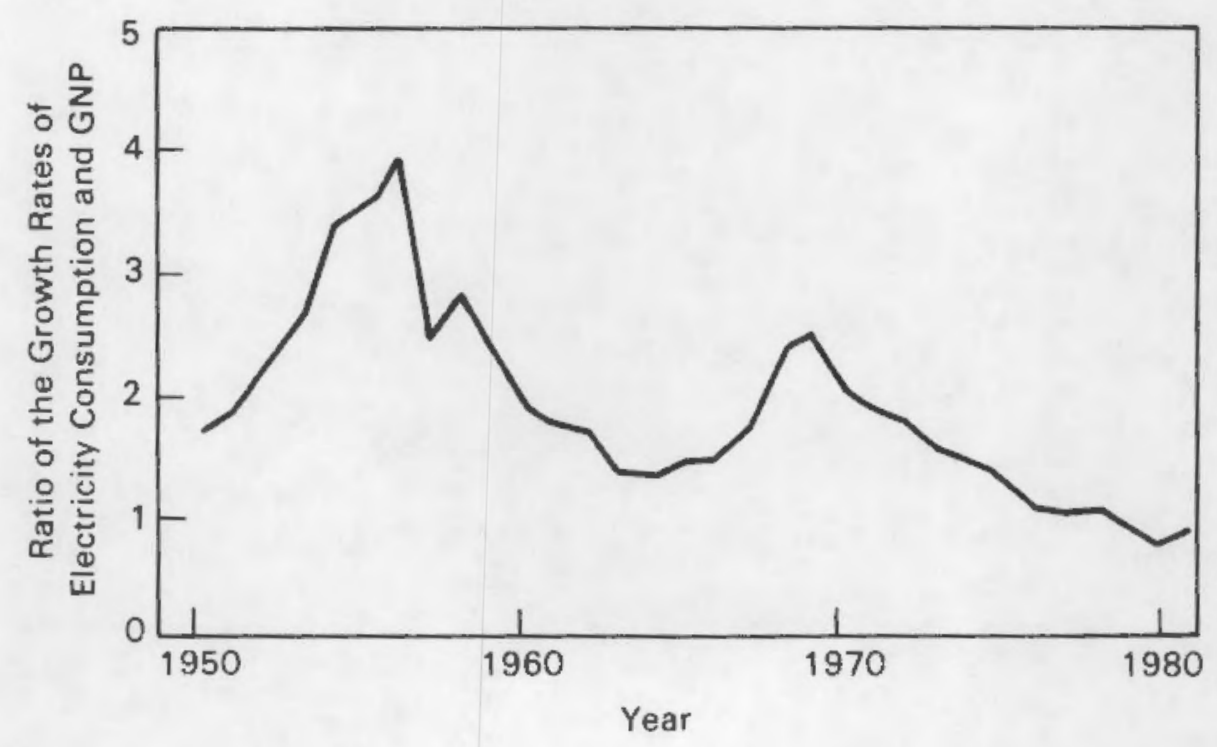

b)

FIGURE 7. Growth Rates of United States Electricity Use and GNP (a) and Ratio of the Growth Rates (b)

Sources: Based on data from Edison Electric Institute, Statistical Yearbook of the Electric Utility Industry, various issues; U.S. Department of Commerce, Bureau of Economic Analysis, National Income and Product Accounts of the United States, 1929-76, Statistical Tables; and Survey of Current Business, various issues (from NRC 86, p. 25). 
most parts of the nation, is a major contributor to the summer peak. Electric heating, common in some regions, contributes to the winter peak. Since yearly weather variations are not predictable, allowance for abnormal weather must be included in the reserve margin. 


\section{PROJECTIONS OF THE NEED FOR NEW GENERATING CAPACITY}

SUMMARY

The need for new generating capacity derives from growth in peak demand, the need for reserve capacity, and the replacement of obsolete capacity. Current 10-year utility planning is based on an average annual growth in peak demand of $2.3 \%$ and an average annual growth in generating capacity of $1.7 \%$. This will reduce the reserve margin, on a nationwide basis, from a current value of over $34 \%$ to a value closer to optimum of about $26 \%$ in 1994 . Utility $f$ recasts predicted summer peak demand of 567 GW in 1994 and a summer generating capacity of $712 \mathrm{GW}$. Most of this new capacity is currently under construction. Of the $108 \mathrm{GW}$ of planned capacity additions between 1985 and 1994, $50 \mathrm{GW}$ will be supplied by coal units and 50 GW will be supplied by nuclear units.

The average lifetime of power plants and the average age of operating plants is increasing. Through 1985, the average age of plants at retirement is 36 years. Plants slated for retirement through the year 2000 will have an average age of 37 years; however, more plants will continue to operate beyond that age. The average age of installed capacity will reach 30 years in 1995, up from the 24 years currently.

The long-term need for new generating capacity is estimated for three scenarios. The scenarios were selected to represent the projected "most likely" situation and high and low extremes. Taking into account currently scheduled capacity additions, additional (currently unscheduled) baseload capacity is required by 1992 under the high scenario, by 1995 under the middle scenario, and by 2005 for the low scenario. In all scenarios, once reserve margins reach target values, annual requirements for new capacity additions increase substantially.

\section{CAPACITY PLANNING}

The need for new generating capacity is derived from three sources: 1) the growth in peak demand, 2) the replacement of obsolete capacity, and 3) the need for reserve capacity. Generating capacity is added, as needed, to meet the projected peak demand, adding a reserve margin to ensure reliability. 


\section{Peak Load}

The peak load and the annual energy demand are the important variables for capacity planning. The peak load is more difficult to forecast than energy demand because of its greater sensitivity to weather and end-use patterns. However, over the long run the national peak load and annual energy demand track each other rather closely (Figure 8) (Hy 85, p. 50). Although the peak load determines the amount of capacity needed, the annual energy demand, as reflected by the load duration curve, determines the type of capacity neeced to meet reliability standards and achieve the lowest cost.

The need for each type of capacity is determined by, the shape of the load duration curve. A typical load duration curve is illustrated in figure 9. The three types of capacity (base, intermediate, and peak) are shown on the right vertical axis. The boundaries between each type are somewhat arbitrary. Assuming that the area, $M$, under the line $A B C$ represents the electricity generated by the baseload capacity, then the average capacity factor for the baseload capacity is $M /(M+N)$. Similarly, assuming that the area $P$ is generated by the intermediate load capacity, then the average capacity factor for the intermediate load capacity is $P /(P+Q)$. Correspondingly, the average capacity factor for the peak load capacity is $R /(R+S)$. Collectively, the average capacity factor of the entire system is $(R+P+M) /(R+P+M+S+Q+N)$. The fraction of electricity generated by the baseload capacity is $M /(M+P+R)$; this is typically on the order of $80 \%$ in many systems. Note that if outages occur in the baseload capacity, particularly during the hours from $A$ to $B$, the baseload capacity would not be able to supply $M$ amount of energy. The deficit in that case would be made up by the other capacity. The area $N$ is mainly used for scheduled outages of base load capacity.

The distribution of the need for baseload or peak load capacity is profoundly impacted by the shape of the load duration curve. This is easily illustrated by two hypothetical extreme examples (Figure 10). In Figure 10a, the need for peaking capacity far exceeds the need for baseload capacity. In Figure $10 \mathrm{~b}$, the reverse is true. 


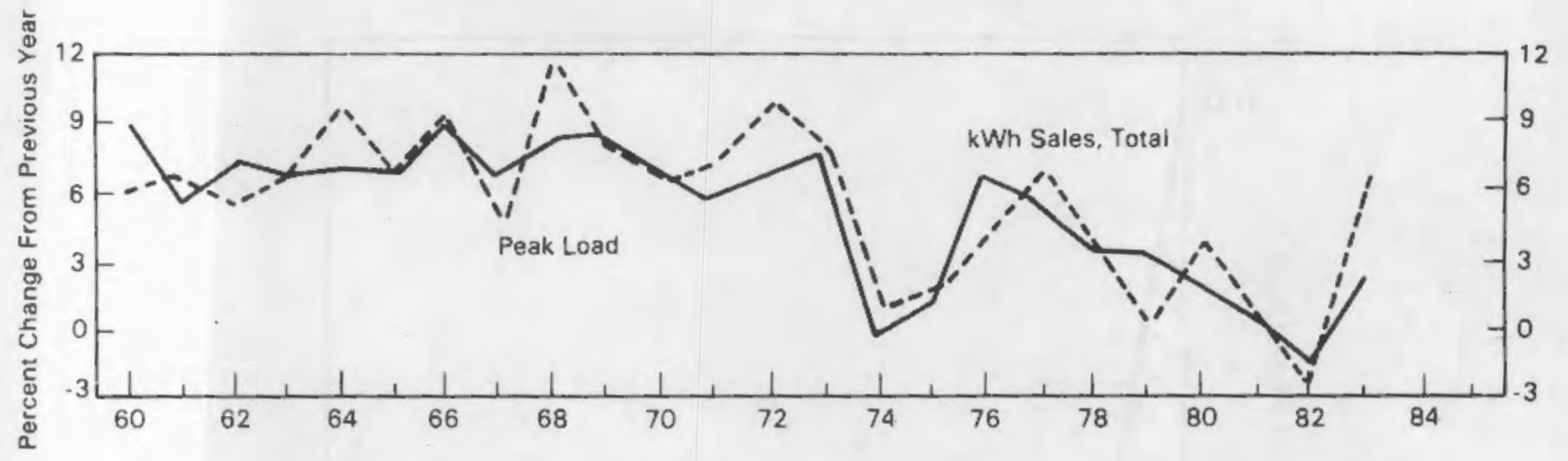

FIGURE 8. Annual National Variations in Peak Load and Energy Sales

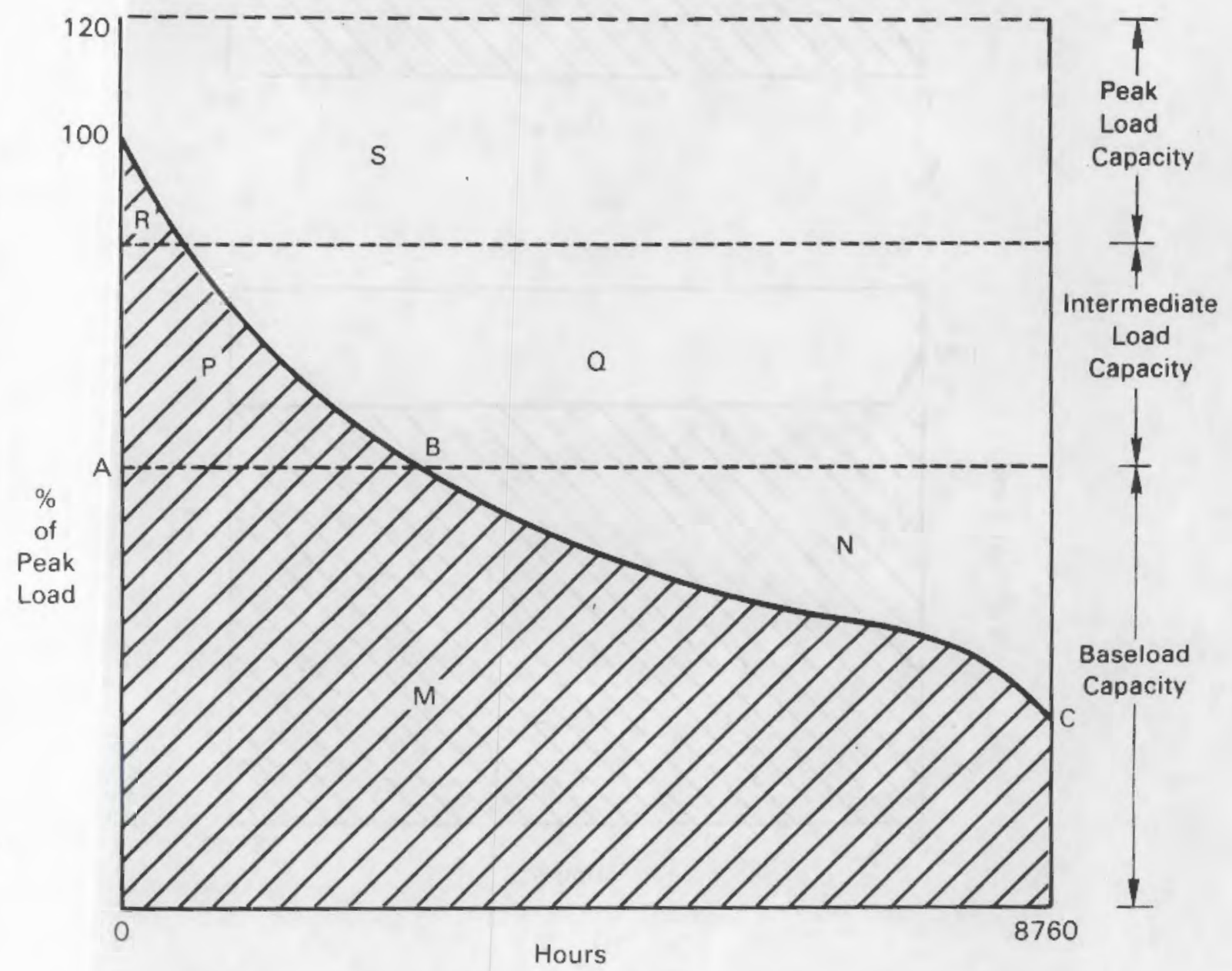

FIGURE 9. Relationship of Typical Load Duration Curve to Generating Capacity

Source: Hyman, L. S. 1985. American Electric Utilities Past, Present, and Future, 2nd ed., p. 50. 


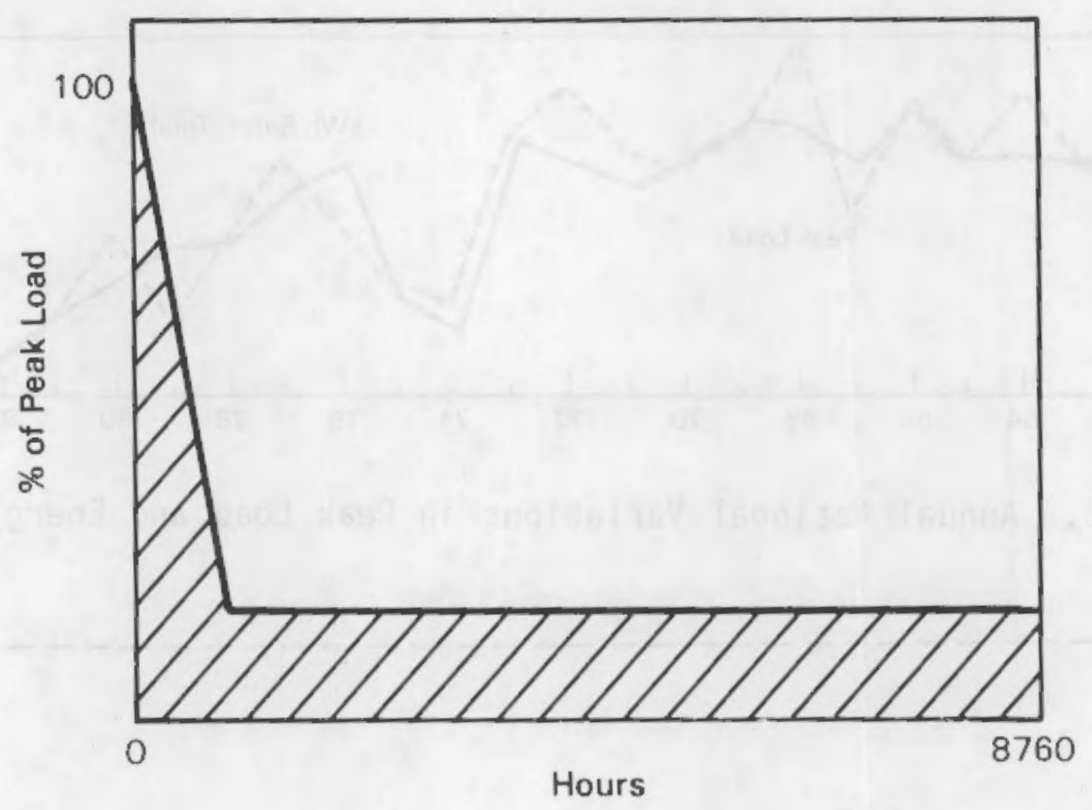

a)

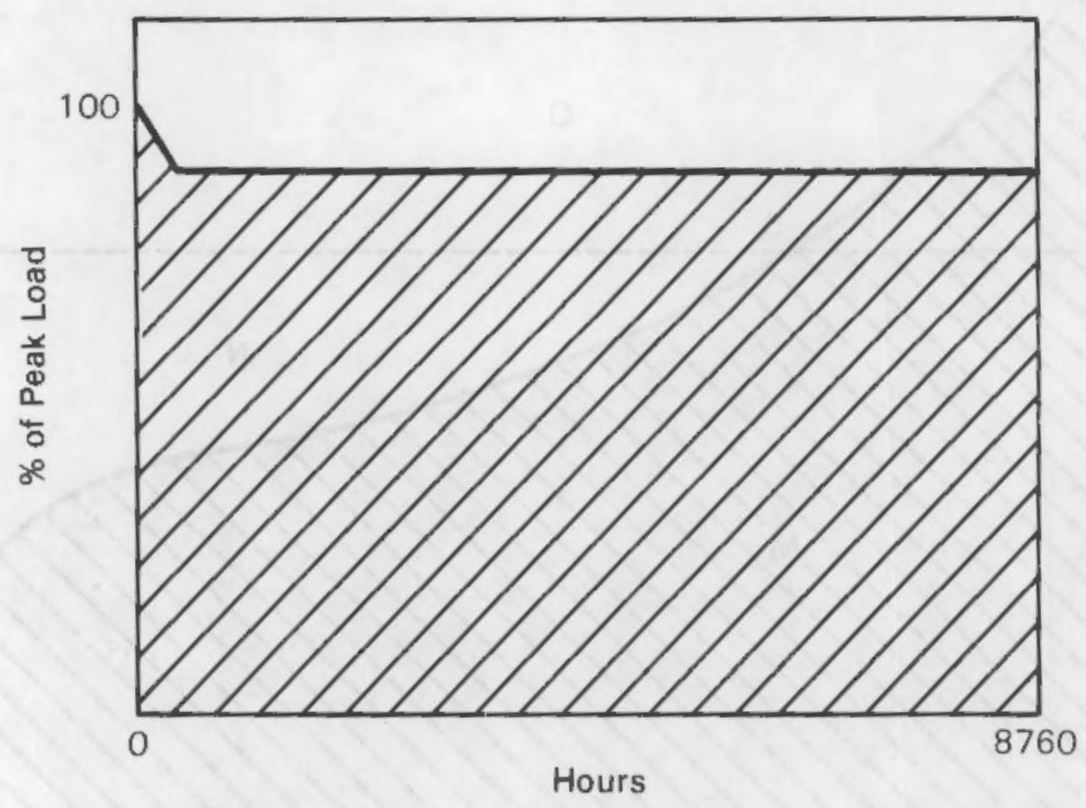

b)

FIGURE 10. Hypothetical Example Illustrating Extreme Diversity in Load Duration Curve 


\section{Reserve Margin}

The reserve margin is the installed capacity above the peak load, expressed in percent, as (Capacity - Peak)/Peak. The margin allows for scheduled outages, forced outages, deratings, and higher than projected peak demands. To meet reliability criteria, $20 \%$ is the rule-of-thumb for the reserve margin. (a) Some suggest a target value of about $25 \%$ (EW 85, p. 56). A study (EPRI 78, pp. S8-S11) for EPRI indicates that the optimum reserve margin for some utilities may be about $30 \%$. However, the optimum reserve margin for a specific utility system depends on the characteristics of that system. On the other hand, load management, time-of-day pricing, and expanded regional interties may enable utilities to operate with lower reserve margins. The lowest reserve margin, nationwide, since 1953 was 16.6\% in 1969 (Hy 85, pp. 85, 103). Reserve margins between 1946 and 1952, however, ranged between $6 \%$ and $14 \%$ (Hy 85 , p. 85). Thus, discounting the low reserve margins in the post World War II years, 15 to $30 \%$ probably covers the optimum range for the national reserve margin.

The term "reserve margin" may be a little misleading. A large fraction of the capacity included in the reserve margin is typically unavailable (out-ofservice) at the peak load. The "available" reserve capacity at the peak is the critical measure of reliability at the peak load. A recent article on reliability (EPRI 86, p. 10) showed that 15 to $18 \%$ of capacity was unavailable at the peak load (Table 2). In 1983, for example, the capacity margin(b) was $25 \%$. However, at the peak $6 \%$ of the capacity was down for maintenance, $6 \%$ was down for forced outages, and $3 \%$ was not available because of partial outages and derating. Thus, $15 \%$ of the capacity was unavailable at the peak, leaving an operating margin (available reserve capacity) of $10 \%$. This is illustrated in Figure 11. Note that the percentages shown in Table 2 refer to the capacity margin and not to the reserve margin.

(a) The $20 \%$ rule-of-thumb for the reserve margin derives from a report by the Federal Power Commission (FPC), titled "The 1970 National Power Survey." The FPC concluded that a $20 \%$ reserve margin industry wide, might be advisable (Senate 85, pp. 1243-1244). This rule-of-thumb value was devised over 15 years ago before the construction of $1000+$ MWe power plants.

(b) The capacity margin is expressed in percent as (capacity - peak)/capacity. 
TABLE 2. U.S. Capacity and Operating Margins(a)

\begin{tabular}{|c|c|c|c|c|c|c|c|c|}
\hline & 1976 & $\underline{1977}$ & $\underline{1978}$ & $\underline{1979}$ & $\underline{1980}$ & $\underline{1981}$ & $\underline{1982}$ & 1983 \\
\hline $\begin{array}{l}\text { Demonstrated U.S. } \\
\text { capacity, GW }\end{array}$ & 485 & 506 & 531 & 544 & 558 & 572 & 586 & 596 \\
\hline Reserve capacity, GW & 125 & 119 & 135 & 146 & 131 & 144 & 171 & 148 \\
\hline Peak demand, GW & 360 & 387 & 396 & 398 & 427 & 428 & 415 & 448 \\
\hline Capacity margin, $\%$ & 26 & 24 & 25 & 27 & 23 & 25 & 29 & 25 \\
\hline Maintenance, \% & 4 & 4 & 5 & 5 & 5 & 5 & 5 & 6 \\
\hline Forced outages, $\%$ & 6 & 7 & 6 & 8 & 7 & 7 & 7 & 6 \\
\hline $\begin{array}{l}\text { Partial outages } \\
\text { and deratings, } \%\end{array}$ & 5 & 5 & 6 & 5 & 5 & 5 & 5 & 3 \\
\hline Unavailability, \% & 15 & 16 & 17 & 18 & 17 & 17 & 17 & 15 \\
\hline Operating Margin, $\%$ & 11 & 8 & 8 & 9 & 6 & 8 & 12 & 10 \\
\hline
\end{tabular}

(a) EPRI 86, p. 10.

RETIREMENT OF OBSOLETE CAPACITY

The need for new capacity additions also depends on the retirement of obsolete capacity, which in turn depends on the average service life of the power plants. The average service 1 ife of plants retired since 1970 is 36 years. However, service life can often be extended to 40 or 50 years or more. Utilities are currently undertaking plant life extension and upgrading programs that could cost a fraction of the cost for new capacity.

The need for replacement capacity in future years can readily be calculated for various service life assumptions. The variation in capacity retirement schedules for existing U.S. generating plants under different service life assumptions is shown in Table 3 . The retirement schedules depend on the capacity installed years earlier. For instance, 31 GW of new capacity was added in 1974. Assuming a 30-year life, this same $31 \mathrm{GW}$ would be retired in 2004. Assuming a 40-year life, this $31 \mathrm{GW}$ would be retired in 2014. Note for the example years, 2004 and 2014, shown in Table 3, how the capacity retired varies with the assumed service life. As noted later, the assumed service life causes some irregularity in capacity projection trends. Historical data on the installed capacity and net capacity additions are provided in Appendix I. 


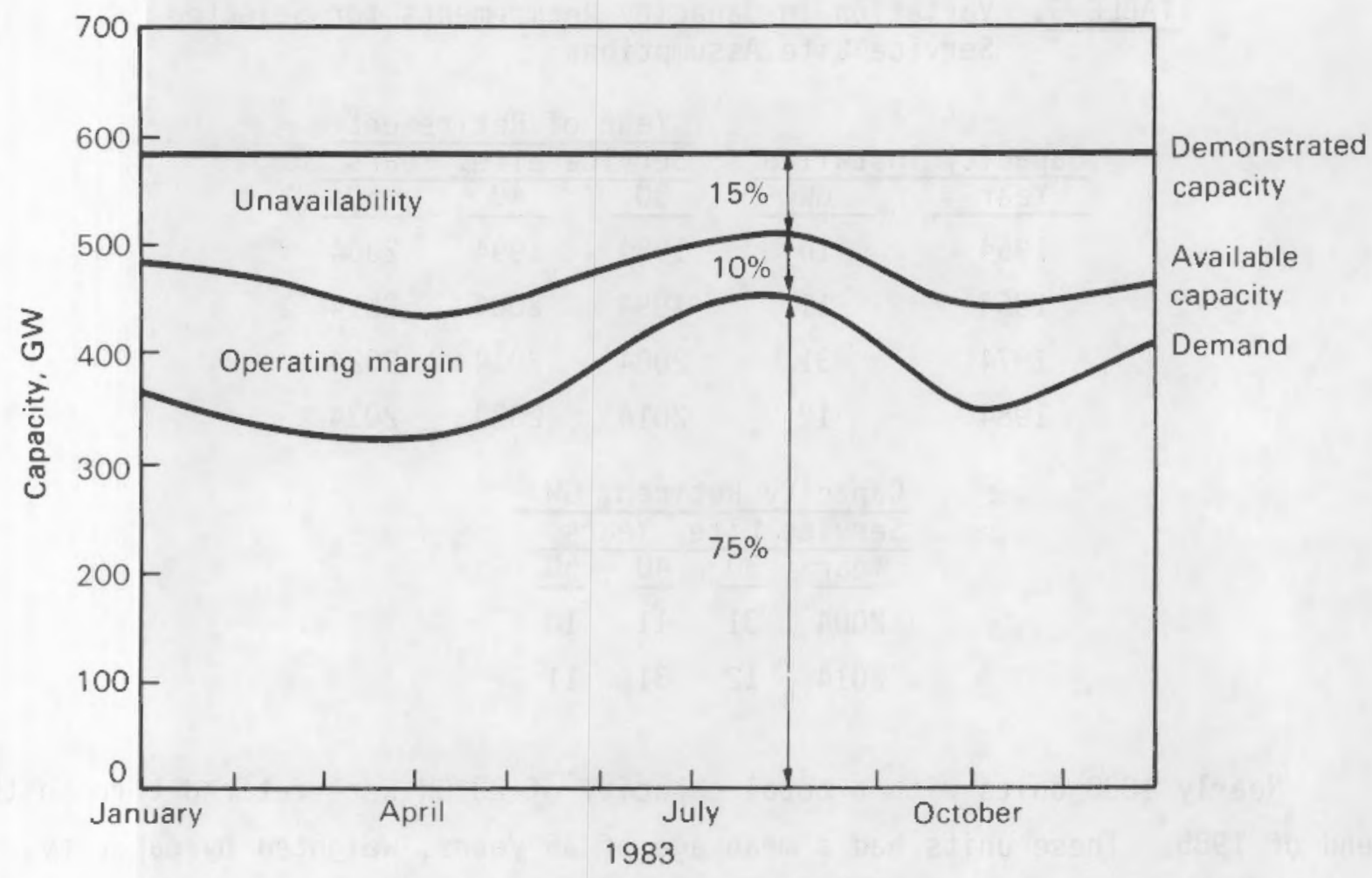

FIGURE 11. Effect of Availability on Margins(a)

Note: Providing reliable electric service requires having reserve capacity actually available when needed. A distinction must therefore be made between the theoretical capacity margin usually quoted and the operating margin provided by readily available plants. During 1983, for example, demand for electricity reached only $75 \%$ of utilities demonstrated capacity, but $15 \%$ of capacity was sometimes unavailable because of preventive maintenance, forced outages, and other causes leaving an actual operating margin as low as $10 \%$ during the summer demand peak.

(a) EPRI 86 , p. 10 . 
TABLE 3. Variation in Capacity Retirements for Selected Service Life Assumptions

\begin{tabular}{|c|c|c|c|c|}
\hline \multirow[b]{2}{*}{ Capacity } & \multirow[b]{2}{*}{ Installed } & \multicolumn{3}{|c|}{ Year of Retirement } \\
\hline & & Service & Life, & Years \\
\hline Year & $\mathrm{GW}$ & 30 & 40 & 50 \\
\hline 1954 & 10 & 1984 & 1994 & 2004 \\
\hline 1964 & 11 & 1994 & 2004 & 2014 \\
\hline 1974 & 31 & 2004 & 2014 & 2024 \\
\hline 1984 & 12 & 2014 & 2024 & 2034 \\
\hline
\end{tabular}

\begin{tabular}{|c|c|c|c|}
\hline$\frac{\text { Capacit }}{\text { Service }}$ & $\frac{y \text { Ret }}{\text { Life, }}$ & $\bar{Y}_{f}$ & GW \\
\hline Year & 30 & 40 & 50 \\
\hline 2004 & 31 & 11 & 10 \\
\hline 2014 & 12 & 31 & 11 \\
\hline
\end{tabular}

Nearly 1800 units with a total capacity of 23 GW were retired through the end of 1985. These units had a mean age of 36 years, weighted by capacity. An additional 400 units with a capacity of 5.3 GW have also been retired, but the startup and/or retirement dates for these units were unknown. The average capacity of the retired units was $13 \mathrm{MW}$. The largest unit retired to date was $200 \mathrm{MW}$. About 800 steam-electric units comprised most (19 GW) of the retired capacity. The average age at retirement was 38 years, weighted by capacity, for the steam electric units. Most of the retired capacity (13.1 GW) had been fueled by oil and gas. Only $200 \mathrm{MW}$ in over 100 small hydro units were retired; their average age was 54 years. The average age of the retired units has remained nearly constant over the past 15 years. Planned retirements by utilities to the year 2000 are $17 \mathrm{GW}$ with an average age of 37 years. The characteristics of the retired plants are summarized in Appendix $D$.

The recent retirement schedule, i.e., 1981-1985, is consistent with replacing 35- to 40-year old plants (Table E.4). However, the planned retirement schedule, through 1995, is more consistent with replacing 50 year old plants. Although the average age of the units to be retired through 1995 is projected to be 36 years, the rate of retirements is less than the installation rate of new capacity 36 years earlier. Thus, the planned retirement schedule, 
if it hoids, reflects overall aging and is consistent with plant life extension programs. The average age of installed capacity would reach 30 years in 1995 , up from 24 years currentiy.

NERC FORECASTS TO 1994

The NERC annually forecasts annual demand, peak demand, and capacity for the next 10 years. The forecast is an aggregation of individual utility system forecasts. NERC represents virtualiy all of the power systens in the United States and Canada.

The 1985 NERC forecast (NERC 85) is for an average annual growth in the summer peak demand and electricity consumption of $2.3 \%$ and an average annual growth in generating capacity of $1.7 \%$ (Table 4 ). The reserve margin at the summer peak demand was $34 \%$ in 1984, and is projected to decrease to $26 \%$ in 1994. After 1995, when the current excess capacity has been reduced to nomal levels, new generating capacity will be needed at a rate to keep pace with the growth in peak demand. NERC projects the U.S. peak demand to be 567 GW in 1994. The U.S. capacity at the peak is projected to be 712 GW in 1994.

In the period from 1985 to 1994,125 GW of new capacity and $17 \mathrm{GW}$ in retirements are planned for a net addition of $108 \mathrm{GW}$. Of the $108 \mathrm{GW}$, increase coal capacity is forecast to increase by $50 \mathrm{GW}$ and nuclear capacity is forecast to increase by $50 \mathrm{GW}$. Planned retirements are concentrated in units using petroleum (7 GW) and gas (7 GW) (DOE 85c, p. 54).

\section{TABLE 4. NERC Forecasts for Selected Years}

\begin{tabular}{|c|c|c|c|c|c|}
\hline & $\begin{array}{c}1984 \\
\text { Actual }\end{array}$ & \multicolumn{3}{|c|}{ Forecasts } & $\begin{array}{c}\text { Average Annual } \\
\text { Increase } \\
1984-1994, \%\end{array}$ \\
\hline Peak demand, GW & 451 & 465 & 520 & 567 & 2.3 \\
\hline $\begin{array}{l}\text { Electricity } \\
\text { Requirements, } \\
\text { Bihions of kwh }\end{array}$ & 2,446 & 2,499 & 2,816 & 3,081 & 2.3 \\
\hline Summer capability, GW & 604 & 617 & 676 & 712 & 1.7 \\
\hline Reserve Margin, 总 & 34 & 33 & 30 & 26 & \\
\hline
\end{tabular}


LONG-TERM PROJECTIONS TO 2035

Over the long-term, electricity demand is expected to track the econony. The econony, as measured by real GNP, has typically grown at the rate of :? to $4 \%$ per year with the long-term average near 3\%. Real GNP should continue :o grow in response to increased population and productivity.

We have projected the peak demand to the year 2035, assuming growth rites of $1.5,2.5$, and $3.5 \%$ (Table 5). The base year is 1984. Using NERC's forecasted installed capacity in 1994 of 712 GW (from Table 4), the projected reserve nargin in 1995 ranges from $181 \mathrm{GW}(34 \%)$ at the $1.5 \%$ growth rate to $53 \mathrm{GW}(8 \%)$ at the $3.5 \%$ growth rate. The projected reserve margin is 130 GW (22\%) at the $2.5 \%$ growth rate. The growth rate assumption is obviously critical to the projected peak demand and the need for new capacity; the peak demand is $300 \mathrm{GW}$ higher in 2005 at the $3.5 \%$ growth rate than at $1.5 \%$. Scenarios for Estimating Long-Term Capacity Needs

Three scenarios were developed to study the range of probabie demands for new capacity. The scenarios vary the peak demand growth rate, the reserve margin, and the retirement schedule since these factors determine the need for new generating capacity. The middle scenario reflects our view of the most likely scenario. The high and low scenarios, which combine the worst case values in each direction, reflect our view of the most likely extreme or boundary conditions. As noted before, the reserve margin applies to the peak

TABLE 5. Projected Peak Demand to 2035

\begin{tabular}{|c|c|c|c|c|c|}
\hline \multirow{2}{*}{$\begin{array}{l}\text { Assumed } \\
\text { Growth Rate }\end{array}$} & \multicolumn{5}{|c|}{ (GW) } \\
\hline & 1995 & 2005 & 2015 & 2025 & 2035 \\
\hline $1.5 \%$ & 531 & 617 & 716 & 831 & 964 \\
\hline $2.5 \%$ & 592 & 758 & 970 & 1242 & 1589 \\
\hline $3.5 \%$ & 659 & 929 & 1311 & 1849 & 2608 \\
\hline
\end{tabular}


demand. The baseload demand and the need for baseload capacity are not affected by the reserve margin. The three scenarios are as follows:

- High-Demand Scenario

Peak Demand Growth $3.5 \%$ per year

Reserve Margin 25\%

Average Service Life 30 years

- Middle-Demand Scenario

$\begin{array}{ll}\text { Peak Demand Growth } & 2.5 \% \text { per year } \\ \text { Reserve Margin } & 20 \% \\ \text { Average Service Life } & 40 \text { years }\end{array}$

- Low-Demand Scenario

Peak Demand Growth $1.5 \%$ per year

Reserve Margin $\quad 15 \%$

Average Service Life 50 years

Total Capacity Requirements

The capacity requirements for each of these scenarios were calculated out to the year 2035 (Table 6; see Appendix $J$ for the complete year-by-year tabulation). By 1995, the difference between the high and low scenarios will grow to $150 \mathrm{GW}$. The planned capacity in 1994 by NERC is 712 GW. This capacity is required in 1991 for the high scenario, in 1994 for the middle, and not until 2004 for the low scenario (Table 7). Under the high scenario, construction would need to be accelerated for plants now under construction, and new

TABLE 6. Capacity Requirements (GW)

\begin{tabular}{|c|c|c|c|c|c|}
\hline Scenario & $1984(a)$ & 1995 & 2005 & 2015 & 2025 \\
\hline High Demand & 6044 & 823 & 1161 & 1638 & 2311 \\
\hline Middle Demand & 604 & 720 & 909 & 1164 & 1490 \\
\hline Low Demand & 604 & 674 & 716 & 823 & 955 \\
\hline
\end{tabular}

(a) Actual capacity. 
TABLE 7. Year in which Curregtly Planned

\begin{tabular}{ll} 
Scenario & Year \\
\hline High Demand & 1991 \\
Middle Demand & 1994 \\
Low Demand & 2004
\end{tabular}

(a) The currently planned capacity is 712 GW in 1994.

capacity commitments would need to be made soon(a) for the post-1991 operation. The middle scenario corresponds closely to current capacity expansion plans. Under the low scenario, current capacity expansion plans would need to be stretched out about 10 years.

The incremental capacity additions to meet projected load growth for each scenario over the 712 GW currently planned for 1994 are summarized in Table 8. For the middle scenario, an additional $197 \mathrm{GW}$ are required by 2005 . For the

TABLE 8. Incremental(a) Capacity Requirements (GW)

\begin{tabular}{|c|c|c|c|c|c|}
\hline Scenario & 1995 & 2005 & 2015 & 2025 & 2035 \\
\hline High Demand & 111 & 449 & 926 & 1599 & 2548 \\
\hline Middle Demand & 8 & 197 & 452 & 778 & 1195 \\
\hline Low Demand & $(38)^{(b)}$ & 4 & 111 & 243 & 397 \\
\hline
\end{tabular}

(a) Incremental to 712 GW already planned for 1994.

(b) Parentheses indicate negative value.

(a) Since new baseload capacity requires a lead time of eight to ten years, additional capacity requirements prior to 1995 would have to be smalier units, such as gas turbines, that could be installed when needed. Other possibilities for the near term are upyrades of existing plants, power purchases, and phase-ins of combined cycle plants. The recent growth rate has been about in line with the middle scenario, indicating that a pick up in the orders for new baseload capacity should occur within the next two years. 
high scenario, an additional 449 GW are required by 2005. For the low scenario, only 4 GW more are required by 2005 , but an additional 111 GW is required by 2015 .

The total new capacity requirements to meet both load growth and the need to replace plants are obtained by adding the retirements to the incremental capacity requirements shown in Table 8 . The retirements of obsolete capacity, after the planned capacity of $712 \mathrm{GW}$ is reached for each scenario, are shown in Table 9. Recall that the retirements are based on the average service life (30, 40, or 50 years) assumed for the high, middle, and low demand scenarios, respectively. The table illustrates the potential effect of extending plant life on the need for new capacity; that is, if a 50-year life is assumed for the high demand scenario, the cumulative retirements to 2035 would be 519 GW, the same as the low demand scenario. The total new capacity requirements (Table 10) are obtained by adding Tables 8 and $y$.

The need for new baseload capacity (Table 11) is estimated to be about $60 \%$ of the total new capacity requirements (see footnote p. 34). The need for new baseload capacity determines the potential need for new nuclear or coal plants. The cumulative need for new baseload capacity to year 2035 , over and above the

TABLE 9. Cumulative Retirement of Dbsolete Capacity (GW)

\begin{tabular}{lrrrrrr}
\multicolumn{1}{c}{ Scenario } & 1995 & $\frac{2005}{20}$ & $\frac{2015}{20}$ & $\underline{2025}$ & $\frac{2035}{4}$ \\
High Demand & 50 & 295 & 455 & 661 & 999 \\
Middle Demand & 11 & 120 & 365 & 525 & 628 \\
Low Demand & 0 & 11 & 120 & 365 & 519
\end{tabular}

IABLE 10. Cumulative Need for New Capacity(a) (Gw) for Both Load Growth and Repiacement of Obsolete Capacity

\begin{tabular}{|c|c|c|c|c|c|}
\hline Scenario & 1995 & 2005 & 2015 & 2025 & 2035 \\
\hline High Demand & 161 & 744 & 1381 & 2266 & 3547 \\
\hline Middle Demand & 19 & 317 & 817 & 1303 & 1823 \\
\hline Low Demand & 0 & 15 & 231 & 608 & 916 \\
\hline
\end{tabular}

(a) Above the currently planned capacity of $712 \mathrm{GW}$. 
TABLE 11. Cumulative Need for New Baseload Capacity (GW)

\begin{tabular}{|c|c|c|c|c|c|}
\hline Scenario & 1995 & 2005 & 2015 & 2025 & 2035 \\
\hline High Demand & 93 & 429 & 795 & 1302 & 2043 \\
\hline Middle Derrand & 11 & 190 & 490 & 782 & 109 \\
\hline Low Demand & 0 & 9 & 145 & 381 & 57 \\
\hline
\end{tabular}

712 GW capacity already included in NERC plans through 1994, ranges from 57 GW in the low scenario to 1094 GW in the middle scenario to 2043 GW in the hij7 scenario. The need for new (in addition to currently scheduled) baseload capacity occurs in 1992 under the high scenario, in 1995 for the middle scenario, and in 2005 for the low scenario.

ANNUAL REQUIREMENTS FOR NEW CAPACITY

Turn now to the annual requirements for new capacity to meet load growth, retirements, and reserve margins. For perspective, consider the steep decline in the annual additions to capacity and the prospects for recovery (Table 1?). The largest additions to capacity, $44 \mathrm{GW}$, occurred in 1973. Since then the has been a general decline. The decline, using NERC 1986 projections, (a) is forecast to bottom out in 1990 at $4 \mathrm{GW}$, a slow pickup to 9 GW in 1995 is projected. Under the middle demand scenario (Table 12), the annual additions lo capacity, above those projected by NERC, would increase rapidly to 31 GW in 1998. However, the retirements under the 40-year service life assumed in the middle demand scenario are much higher than the retirements planned for the 10 preceding years. Thus, if longer service lives did prevail and plant retirements were lower, the annual capacity additions would be smaller than shown. Nonetheless, annual capacity additions would increase to over 20 (aw y the year 2000 .

The annual requirements for the three scenarios are sumarized for selected years in Table 13. For example, 67 GW of new capacity are required ' $n$ the year 2005 under the high demand scenario. Keep in mind that approximately

(a) The 1986 projections used here became available after the preceding analysis was complete. The preceding analysis used the NERC 1985 projections. 
TABLE 12. Annual Additions to U.S. Generating Capacity (GW)

\begin{tabular}{|c|c|c|c|}
\hline Year & $\begin{array}{l}\text { Annual } \\
\text { Additions }\end{array}$ & Retirements & Net Additions \\
\hline 1973 & 44 & 1 & 43 \\
\hline 1974 & 37 & 1 & 36 \\
\hline 1975 & 31 & 1 & 30 \\
\hline 1976 & 24 & 1 & 23 \\
\hline 1977 & 30 & $i$ & 29 \\
\hline 1978 & 20 & 1 & 19 \\
\hline 1979 & 20 & 1 & 19 \\
\hline 1980 & 17 & 1 & 16 \\
\hline 1981 & 24 & 3 & 21 \\
\hline 1982 & 18 & 3 & 15 \\
\hline 1983 & 11 & 3 & 8 \\
\hline 1984 & 17 & 3 & 14 \\
\hline $1985(b)$ & 26 & 2 & 24 \\
\hline
\end{tabular}

NERC 1986 Projections (1986 - 1995)

$\begin{array}{llrr}1986 & 16 & 1 & 15 \\ 1987 & 17 & 1 & 16 \\ 1988 & 10 & 1 & 9 \\ 1989 & 4 & 1 & 3 \\ 1990 & 4 & 1 & 3 \\ 1991 & 8 & 1 & 7 \\ 1992 & 7 & 2 & 5 \\ 1993 & 5 & 1 & 3 \\ 1994 & 7 & 1 & 6 \\ 1995 & 9 & & 8 \\ \text { Middle scenario } & (1995-2000) & & \\ 1996 & 14(a) & 6 & 8 \\ 1997 & 26 & 7 & 19 \\ 1998 & 31 & 12 & 19 \\ 1999 & 32 & 13 & 19 \\ 2000 & 30 & 10 & 20\end{array}$

(a) An additional 10 GW over the NERC projections would be required in 1995 under the middle demand scenario to replace retired plants that were originally brought online in 1955.

(b) Based on preliminary EIA data for 1985. 
TABLE 13. Annual New Capacity Requirements (a) (GW)

\begin{tabular}{|c|c|c|c|c|c|}
\hline Scenario & 1995 & 2005 & 2015 & 2025 & 2035 \\
\hline High Demand & 40 & 67 & 68 & 106 & 150 \\
\hline Middle Demand & 19 & 35 & 56 & 49 & 55 \\
\hline Low Demand & 3 & 15 & 25 & 42 & 23 \\
\hline
\end{tabular}

(a) For growth and replacement of retired plants.

$67 \mathrm{GW}$ are also required in 2006, 2007, etc., since these are annual requirements. The annual requirements are somewhat erratic in that the retirements in a given year reflect historical piant additions. For instance, the peaks in 2015 and 2025 for the middle and low scenarios, respectively, are caused by replacing plants that began service in 1975 according to the assumed 40- anj 50-year retirement schedules, respectively, for these scenarios. Plant additions in 1975 were unusualiy high compared to additions in 1965 and 1985. "he total new capacity requirements include the need for peaking capacity, loadfollowing capacity, and baseload capacity.

We estimate the annual need for new baseload capacity (Table 14) to be approximately $60 \%(a)$ of the total new capacity requirements previously shown in Table 13. The annual need for new baseload capacity is used below to arrive at an estimate of the maximum plant size that would be needed on a regional basis. Regional Capacity Needs

There is a potential demand for new large baseload units or multiple sma! 1 units in all NERC regions under all scenarios. We estimated the need for new baseload capacity in each NERC region (Table 15) for the middle demand scenario by distributing the total national demand. The distribution was prorated based

(a) Assume that the shape of the load duration curve renains constant; i.e., that the baseload grows proportionally to the peak demand. With a $20 \%$ reserve margin, assume 60\% of new capacity is baseload. Adjust the 60\% slightly for the higher and lower reserve margins since the reserve margir. does not change the shape of the load duration curve. 
TABLE 14. Annual Need for New Baseload Capacity (GW) in Selected Years (a)

\begin{tabular}{|c|c|c|c|c|c|}
\hline Scenario & 1995 & 2005 & 2015 & 2025 & 2035 \\
\hline High Demand & 23 & 39 & 39 & 61 & 86 \\
\hline Middle Demand & 12 & 21 & 34 & 30 & 33 \\
\hline Low Demand & 2 & 9 & 16 & 26 & 14 \\
\hline
\end{tabular}

(a) For load growth and replacement of retired plants and assuming baseload capacity is 0.72 times peak demand.

TABLE 15. Annual Need (MWe) for New Baseload Capacity by NERC Region for the Middie Demand Scenario

$\begin{array}{lrrrr}\text { NERC Region }(a) & \frac{1995}{1,700} & \frac{2005}{3,000} & \frac{2015}{4,900} \\ \text { ECAR } & 1,100 & 2,000 & 3,200 \\ \text { ERCOT } & 800 & 1,500 & 2,400 \\ \text { MAAC } & 800 & 1,500 & 2,400 \\ \text { MAIN } & 600 & 1,000 & 1,600 \\ \text { MAPP-US } & 1,000 & 1,700 & 2,700 \\ \text { NPCC-US } & 2,600 & 4,600 & 7,400 \\ \text { SERC } & 1,200 & 2,200 & 3,000 \\ \text { SPC } & \underline{2,100} & \underline{3,700} & \underline{6,000} \\ \text { WSCC } & 12,000 & 21,000 & 34,000 \\ \text { NERC-US TOTAL } & & & \end{array}$

(a) See Appendix H (p. H.I) for NERC Region Explanations. 
on projected summer peaks in 1994. (a) Under the middle scenario, there is a need in 1995 for large baselaad capacity in each region, beyond that aireaty planned. The need, of course, is even greater and sooner for the high scr.nario. Under the low scenario, new capacity, beyond that already planned, is not required until 2005, but a potential need for new large baseload units occurs in each region at that time. The need can be met by either large single units or multiple small units.

Planning Uncertainties

The differences in capacity requirements between the high and low scenarios are enormous. Translated into dollars, the differences reach into the hundreds of billions. The high and low scenarios, we believe, bound the range of future capacity demands and illustrate the magnitude of the uncertainties facing capacity pianners. Fortunately, pianning horizons are shorter and flans can be adjusted as events unfold. But, as we have seen, adjustments to abrupt changes in demand, such as occurred in 1973, can take a long time.

Planning uncertainties deal with demand projections and what drives th.m. Apparent drivers are GNP, price elasticity, and inter-fuel competition. Underneath lies a web of complex relationships, constantly changing with economic: and social activity.

One of the obvious factors that affects uncertainty is the length of tre lead time between the capacity addition decisions and plant startup. The rate of divergence (2\% per year) between the low and high projections provides a measure of the relationship of uncertainty to lead time. For instance, for each year the lead time is shortened or lengthened, the uncertainty in the capacity requirements for a future target year is reduced or increased, respestively, about two percent, or about 14 Giw currently.

(a) This distribution assumes that post-1994 regional growth rates would correspond to the national average $(2.5 \%)$ and that plant retirements could also be prorated on the same basis. In Table 1 the projected regional growth rates to 1994 varied from 1.1 to $3.6 \%$ per year for the peak load. This range nearly corresponds to the growth rates for the three scenarios. Our purpose is to point out that a potential should exist for largi? plants in all or nearly all regions by 2005, especially if the needs for two consecutive years can be combined. 
SUPPLY UPTIONS

\section{SUMMARY}

Nearly all (95\%) of the electricity generated in 1985 came from coal $(56.8 \%)$, nuciear $(15.5 \%)$, hydro $(11.4 \%)$, and natural gas $(11.7 \%)$. The remaining $5 \%$ came from petroleum $(3.7 \%$ ) and other sources (1.1\%). In 1984, 4366 active power plants generated electricity, but $90 \%$ of the electricity produced was generated by only $12 \%$ of the plants.

During the next decade, about 100 GW of new baseload capacity and 20 GW of other capacity is scheduled to be added. Most of this new baseload capacity will be comprised of either coal or nuclear plants. By 1994 the installed capacity represented by nuclear plants will have increased to $16 \%$ from $10 \%$ in 1984. If additional capacity is required, beyond that currentiy planned, it will most likely consist of small blocks of peaking capacity that can be brought on-line quickiy (e.g., gas turbines).

It is expected that for several decades beyond the mid-1990s, electricity supply will continue to come from many sources, but that the primary sources will continue to be baseload coal and nuclear plants. Only coal and nuclear have the extensive domestic fuel reserves and proven technology to reliably provide large blocks of power at low costs. While the relative contribution of hydro and petroleum is expected to decrease, the contribution of alternative energy sources is expected to increase. 


\section{EXISTING CAPACITY AND GENERATION}

At the end of 1985 there were 10,904 generating units with a total nianeplate capacity of $696 \mathrm{GW}(a)$ in the United States. Their sizes ranged fran $10 \mathrm{KW}$ to 1372 MWe or 6 orders of magnitude (Table D.1). In general, most uf the older units were smaller and were installed originally to meet local demands. The newer units were generally larger and were installed to meet regional demands. The age and size distribution is summarized in tables liz-06 in Appendix $D$.

The large units typically provide baseload capacity, and smaller units usually provide intermediate and peak load capacity. The large units take advantage of economies of scale in design and operation and have the lowest unit electrical generation cost when operated at high capacity factors. Peaking units, on the other hand, are able to startup quickly and usually have the lowest cost at low capacity factors. Many older units, originally operated as baseload units, are converted to intermediate or peak load operation when sheir variable (operating and fue1) costs exceed those of new baseload units. The boundaries between peak load, load-following, and baseload are not clear-cut. Rather, the units in a system represent a continuum with the operation of each unit selected to minimize total generation cost while reliably meeting the total demand.

In 1984, 4366 "active" power plants generated electricity out of a total of 5692 "active" and inactive power plants. A power plant consists of one or more generating units. For example, Wanapurn Dam, a power plant of 831 Mh, zonsists of ten $83.1 \mathrm{MW}$ units (turbine/generators). However, $24 \%$ of the electajcity was generated by on $7 y 46$ (1\%) power plants that, on average, generated

(a) This is the EIA 1985 year-end capacity based on a data tape available " February 1986. The 1984 NERC capacity of $604 \mathrm{GW}$, used previously, is based on summer ratings at the summer peak. The NERC summer capacity figure is about 10 percent below the year end nameplate capacity reportted by the EIA. In 1984 , EIA reported a year-end capacity of $672 \mathrm{GW}$. Several factors account for the difference. EIA includes Alaska, Hawai $i$, and Puerto Rico. NERC includes virtually all power systems in the contigucus states only. The NERC capacity is based on the derated capacity, part?y due to higher summertime temperatures of the cooling water, rather than the nameplate capacity. EIA includes capacity added after the summer peak. 
over 10 billion $\mathrm{kWh}$ each (Table 16). Over half of the electricity was generated by $4 \%$ (158) of the active power plants, and $90 \%$ of the electricity was generated by only $12 \%$ of the active power plants. Thus, based on percentage, comparatively few power plants generate nearly all of the electricity. Conversely, $88 \%$ of the active plants generated only $10 \%$ of the electricity. (a) The rows in Table 16 were based on power plants generating over 10, 5, 3, and 1 billion $\mathrm{kWh}$ in 1984. Keep in mind that over 1300 plants were inactive in 1984.

In 1985 (NERC 86), coal-fired units had the largest capacity (272 GW), followed by dual (oil/gas) ( $87 \mathrm{GW}$ ), nuclear $(71 \mathrm{GW})$, conventional hydro (70 GW), $0 i 1(60 \mathrm{GW})$, gas $(44 \mathrm{GW})$, and other (17 GW) (Figure 12). Other includes pumped storage, geothermal, solar, refuse, and wood. By energy generation (Figure 13), coal ranked first $(57 \%)$, followed by nuclear $(16 \%)$, natural gas $(12 \%)$, conventional hydro $(11 \%)$, oil $(4 \%)$, and other $(1 \%)$. (Totals add to $101 \%$ due to rounding.) The capacity data represents the summer capability.

The current situation is one of surplus capacity. From 1985 through 1995 , 87 GW of new capacity is scheduled to be added. Most of this new capacity is

TABLE 16. Power Generation in 1984 by Type of Power Plant

\begin{tabular}{|c|c|c|c|c|c|c|c|c|c|}
\hline Cumulative & $\begin{array}{l}\text { Cumulative } \\
\text { Percentage }\end{array}$ & & & & Cums & Iative & Number of & Plants & \\
\hline $\begin{array}{c}\text { Generation } \\
\text { (\$) }\end{array}$ & $\begin{array}{l}\text { of Plants } \\
\text { (\$) }\end{array}$ & $\begin{array}{l}\text { Generation } \\
\text { Per Plant }(a) \\
\end{array}$ & Total & Coal & Nuclear & Hydro & $\begin{array}{c}\text { Natural } \\
\text { Gas } \\
\end{array}$ & $\begin{array}{r}\text { Fuel } \\
011 \\
\end{array}$ & Geotherma I \\
\hline 24 & 1 & $>10$ & 46 & 30 & 10 & 4 & 2 & $=-$ & -- \\
\hline 56 & 4 & $>5$ & 158 & 99 & 34 & 10 & 11 & 3 & 1 \\
\hline 71 & 6 & $>3$ & 258 & 165 & 47 & 16 & 24 & 5 & 1 \\
\hline 90 & 12 & $>1$ & 511 & 292 & 60 & 41 & 84 & 33 & 1 \\
\hline
\end{tabular}

(a) Billions of kwh.

(a) Based on information contained in computerized data base of United States Power plants compiled by DOE, Energy Information Administration, February 1986. 


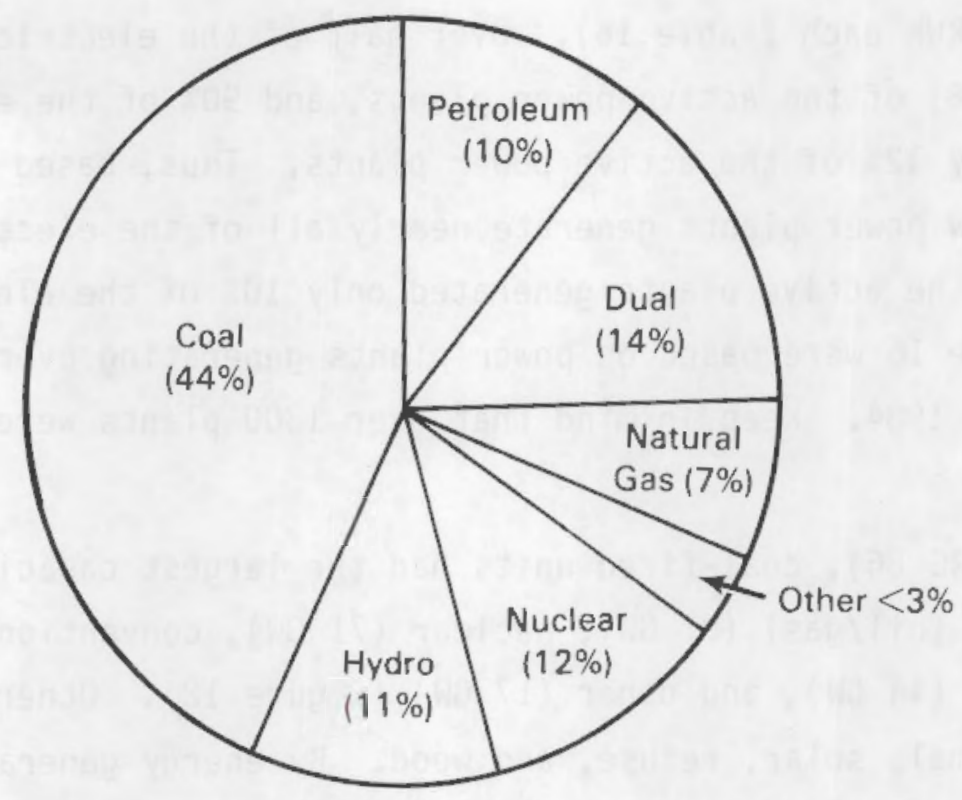

FIGURE 12. Generating Capacity by Fuel Type (1985)

Note: Dual uses either natural gas or petroleum.

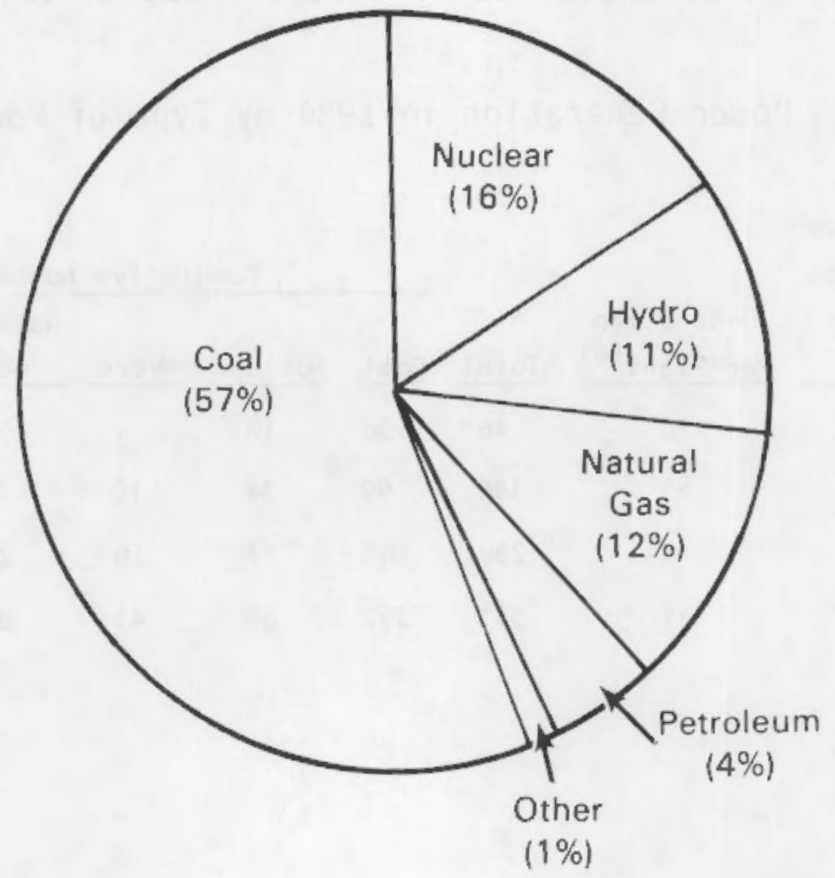

FIGURE 13. Electricity Generation by Fuel Type (1985) Note: Totals equal $101 \%$ due to rounding. 
comprised of coal (31 GW) and nuclear (30 GW) piants. Nearly all of the new capacity is currently under construction. Should additional capacity be required, smaller blocks of peaking capacity, such as gas turbines, would be brought in quickly, perhaps as part of a staged-construction, combined-cycle plant (E0 86, p. 1).

Conservation has not played as important a role in electricity usage as in overall energy usage. A crude measure of conservation is the productivity of electricity as measured by the ratio of real GNP to electricity generation. There has been only a slight increase (3\%) in this ratio over the last decade. In contrast, the ratio of real GNP to overall energy consumption has increased about $30 \%$ over the same period (Hy 85, p. 101). The slight increase in electricity productivity could be caused by shifts in the economy away from electricity consuming industries. However, decreases in electricity consumption per unit of output did occur in the top four electricity intensive industries, chemicals, paper, primary metals, and food processing. Conservation was also important in the residential and commercial sectors. Over the last four years electricity demand in these sectors declined although the sectors grew at a faster rate than GNP (DOE $85 b$, pp. 21-39).

FUTURE SUPPLY OPTIONS

The future electricity supply is expected to come from many sources, but only coal and nuclear currentiy have the extensive domestic reserves and proven technology to reliably provide large blocks of low cost power. Therefore, under present conditions the future electricity supply is expected to be generated primarily by coal and nuclear baseload plants and existing large hydroelectric plants. Baseload plants are expected to comprise about $60 \%$ of future capacity and produce about $80 \%$ of the electricity. The remaining $40 \%$ of capacity is expected to be load-following, non-firm, and peak load plants. Hydroelectric, natural gas, oil, solar (wind, photovolatics, solar-thermal, biomass, etc.), coal, geothermal, and cogeneration are expected to provide most of this capacity and will produce about $20 \%$ of the electricity. Canadian imports are expected to increase and become an important supply, particularly in the Northeast. In 20 to 40 years, breakthroughs in fusion and breeder reactors could 
lead to the commercialization of these technologies. Since new developmerts frequently alter the competitive situation, pursuing diverse energy options is advantageous and avoids dependency on a single option. 


\section{RESOURCE CONSUMPTION AND WASTE PRODUCT GENERATION}

\section{SUMMARY}

This section estimates the resource consumption and waste generation for the coal and nuclear fuel cycles for three scenarios. One scenario assumes the phasing out of nuclear and its replacement with coal over the long-term. The opposite scenario assumes the phasing out of coal and its replacement with nuclear. The middle scenario assumes a 50/50 split in new baseload capacity between coal and nuclear. These scenarios cover the extreme ranges of coal and nuclear usage expected over the long-term. The 50/50 split corresponds to recent experience and planned construction through 1994.

Even under the extreme scenarios, domestic coal and domestic uranium resources are sufficient to meet the projected demand. However, exclusive use of domestic resources does result in a significant depletion of those reserves by 2035:

PERCENT OF DOMESTIC RESOURCES CONSUMED THROUGH 2035

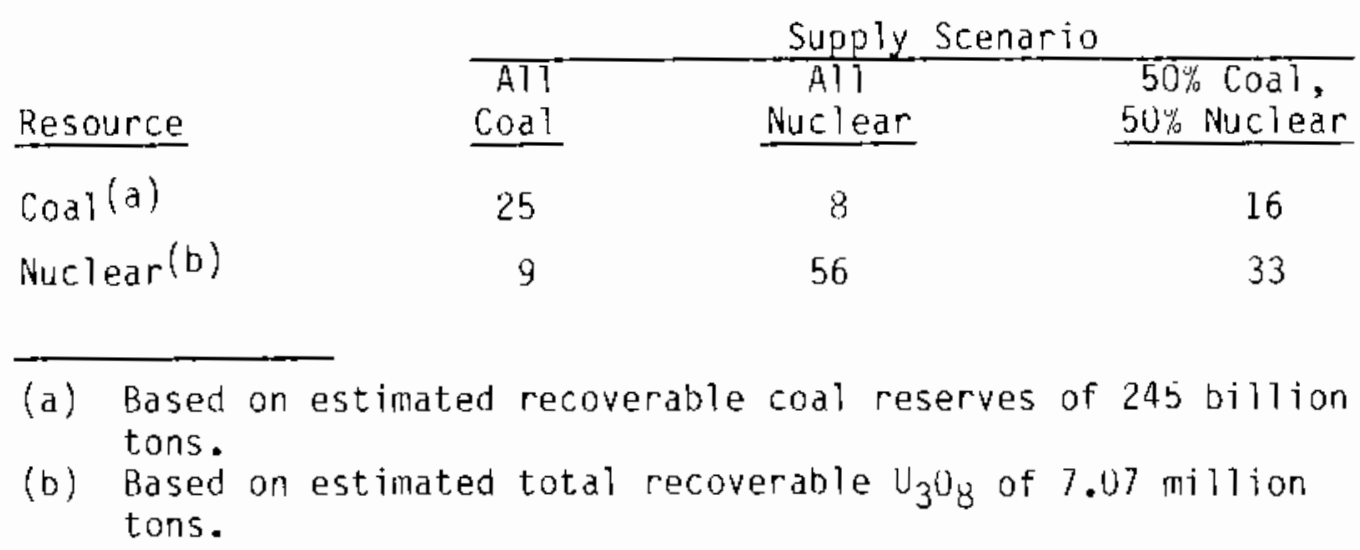

No supply problems will necessarily occur in any part of either fuel cycle because the required growth rates are low and lead time for capacity expansion of critical fuel cycle services are exceeded by the lead times required for power plant construction. Under the all-nuclear scenario, demand will equal 
the current United States uranium enrichment capacity (including a nonoperating facility currently on "standby") in about 2005 . Under the $50 \%$ nuclear scenario, demand is projected to equal enrichment capacity in 201 's.

The fuel requirements and waste generation from coal plants are huge :ompared to nuclear. These requirements make coal generation more susceptib a to future supply disruption (in mining and transportation) and inflation than nuclear. Low-cost technology is available to handle the coal supply and waste generation under existing regulations. However, changes in these regulations in response to environmental concerns could lead to restrictions on coal wage and large cost increases.

\section{INTRODUCTION}

Previous sections of this report clearly identify the need for new biseload electricity generation plants, beyond those already scheduled, before the year 2000. Based on current experience, coal and nuclear technologies are unique in their proven ability to provide low cost electricity using domestic fuel reserves and in their potential for significantly increased utilizaticn. It is apparent that both technologies will play a role in the future; however, the relative roles of the two technologies is subject to questions.

Aside from meeting the pure demand requirements, other factors influence decisions on the relative roles of nuclear vs. coal technologies. These factors include economics, reliability of the fuel supply, waste product generation and disposal, environmental and health concerns, and public acceptability.

The purpose of this section is to assess the requirements for critical resources and to estimate the quantities of wastes generated for future sujoly scenarios involving various mixes of coal and nuclear plants. Projections of resource requirements and of impacts in terms of waste generated provides 1 perspective for formulating long range research and development plans to improve technology, mitigate adverse impacts, assure the availability of c-itical resources, and to increase the utilization of potential by-products.

Comparisons in fuel requirements, transportation and processing needs, and waste generation and disposal are made for three scenarios that assume that. 
most new baseload power plants are: 1) all coal, 2) all nuclear, and 3) 50\% coal, $50 \%$ nuclear. The assessments are based on utilization of existing technologies.

Two important effects, health and safety, are beyond the scope of this analysis. Legislation and regulations prescribe the acceptable levels of risk to society for a technology. The acceptable levels of risk attempt to strike a proper balance between the benefits and costs to society. The ALARA, "as Iow as reasonably achievable," principle applied to radiation protection reflects society's desire for a proper balance, for example.

Past work on health and safety risks of the coal and nuclear fuel cycles are not conclusive. In a May 1984 study (Fi 84) Sandia National Laboratories evaluated the literature on coal and nuclear fuel cycle risk comparisons. They concluded that 1) the inadequacies in existing analyses could be removed with better data on heaith effects of the coal fuel cycle, 2) more appropriate metrics were needed to compare the coal and nuclear fuel cycles, 3) health effects models for the coal fuel cycle were simplistic compared to those for the nuclear fuel cycle, 4) the lack of rigor among analysts in precisely defining the aspect of the fuel cycle being addressed made comparisons difficuit, 5) the credibility and acceptability of existing comparisons was questionable, and 5) additional work was required in the areas of socioeconomic and sociopolitical impacts assessment to obtain more creditable/acceptable risk comparisons.

\section{ASSUMPTIONS USED IN THE SCENARIOS}

We assumed that the proportion of coal plus nuclear generation to the total generation in 1984 would remain constant. In 1984, 68\% of the total electricity generation was coal plus nuclear.(a) We assumed that the generation would grow at the rate of $2.5 \%$ per year. We assumed that the

(a) By implication we assume that 32 percent of the future electricity generation will come from other fuels. We expect those to be hydro, natural gas, oil, geothermal, solar, etc. Current trends point to a decline in the percentage of hydro, natural gas, and oil. If the trends continue, this as 'llion would imply substantial growth in the alternative generat, technologies. 
nuclear plants under construction would be completed by 1994 according to VERC plans. We further assumed that the nuclear plants would increase their a/zrage capacity factor from $60 \%$ in 1984 to $65 \%$ in the year 2000 . For simplicity, all steps of each fuel cycle were assumed to occur in the same year as power production.

In the all-coal scenario, no new nuclear plants are ordered. The coil generation is calculated by subtracting the nuclear generation from the total coal plus nuclear generation. The nuclear plants are retired 40-years af aer startup; nuclear generation reaches zero in 2035 .

In the all-nuclear scenario, coal yeneration is calculated in 1994 as above. This generation is reduced to zero in 2035 in proportion to the generation capacity retired, assuming a 40-year plant life. The nuclear generation is then obtained by difference.

The impacts of the half-coal/half-nuclear scenario were estimated to be midway between the all-coal and all-nuclear scenarios.

DESCRIPTION OF COAL AND NUCLEAR FUEL CYCLES

A brief description of the steps in each fuel cycle is presented belit. The assumed values are representative of current technology for each fuel cycle. Coal Fuel Cycle

Coal is produced from underground and surface mines. Most of the uncerground production $(65 \%)$ is in the eastern United States (NCA 85, p. 30). The western mines which produced $35 \%$ are primarily surface mines. Most reserves are in the west; the proportions of production in the west should gradually increase. Eastern coal is generally higher in sulfur content and heating value than western coal. Underground mining is mostly room and pillar with some long wall mining.

Coal varies widely in properties important to its use as a utility fuel. The sulfur content may range from 0.6 to $6.0 \%$. The ash content usually ranges from 8 to $12 \%$, although much nigher values are possible. The heating values range from $6,000 \mathrm{Btu} / 1 \mathrm{~b}$ for lignite to $14,000 \mathrm{Btu} / 1 \mathrm{~b}$ for bituminous. As mined, 
coal is diluted with additional impurities. Coal preparation plants, located near the mine, remove most of the mine waste. Mine waste can range from negligible amounts to $30 \%$ or more. The coal composition and utilization assumptions used in this study are summarized in Table 17.

After mining, the coal is sorted, cleaned, and sized. The mine waste is dumper in waste embankments. Some is returned to the mine for back fills. The waste frequently contains a large fraction of low-grade coal and other carbonaceous material. Disposal practices must guard against potential combustion and structural instability of the embankments. Coal handling near the mine is usually by truck or conveyor.

After cleaning, the coal is transported to the power plant. Several methods are used: unit trains, mixed trains, barges, trucks, and slurry pipelines. Train haulage is most common. Coal haulage by barge, truck, conveyor, and slurry pipeline make up the $36 \%$ not hauled by rail. Barging is generally the lowest cost if access to waterways is convenient. Trucks are used for short haulage. Only a few slurry pipelines have been built and operated.

At the power plant, the coal is stored in stock piles. Nominally, a 60-day supply is maintained as a precaution against supply disruptions.

The combustion of coal produces fly ash, bottom ash, $\mathrm{SO}_{2}, \mathrm{NO}_{x}$, and $\mathrm{CO}_{2}$. Fly ash is collected by filters and electrostatic precipitators; bottom ash collects at the bottom of the furnace. $\mathrm{SO}_{2}$ is removed by flue gas desulfurization (FGO) processes, and in the future, by fluidized bed combustion techniques. The $\mathrm{NO}_{x}$ emissions are reduced by scrubbing and control of the combustion conditions. $\mathrm{CO}_{2}$ emissions are not controlled.

Ash and sludge from the FCD process are disposed of in land fills, although some is utilized in by-products.

With present technology and emission standards, coal plants are roughly equal to nuclear plants on a unit cost of power basis. Coal plants cost less to build but require higher fuel costs than nuclear plants. Electricity from coal plants is thus more susceptible to future escalation of fuel costs than nuclear piants. 
TABLE 17. Assumptions Used in Coal Fuel Cycle Anaiysis

\section{Composition}

Heating value of as-burned coal: 21,000,000 Btu/ton, 10,500 Btu/10 $8,500 \mathrm{Btu} / \mathrm{kWh}$ (heat rate)

Sulfur Content: $2.0 \%$

Ash Content: 10.0\%

Mine Waste: $16.0 \%$

Mine Waste Properties (a)

$\begin{aligned} \text { Dry Density } & =90 \mathrm{ft}^{3} \\ \text { Wet Density } & =106 \mathrm{ft}^{3} \\ \text { Specific Gravity } & =1.95\end{aligned}$

Sludge from Coal Preparation Plants (b)

$\begin{array}{ll}\text { Dry Density } & =54 \mathrm{ft}^{3} \\ \text { Wet Density } & =78 \mathrm{ft}^{3} \\ \text { Specific Gravity } & =1.36 \text { to } 1.66\end{array}$

Coal Transport

90 tons coal/carload

100 cars/train; total length - 5,500 feet

Average speed $=10 \mathrm{miles} /$ hour

Average distance $=1,800$ miles round trip

Fraction hauled by rail $=64 \%$

Coal car utilization $=2,160$ hours per year

(hauling coal and returning)

Power Plant Waste Products (EPRI 84, pp. 3-50 to 3-53)

Solid Waste

Total ash = Coal consumption $\times 0.10$

Total fly ash $=$ Total ash $\times 0.8$

Fly ash collected in precipitator = Total fly ash $\times 0.9$

Total bottom ash $=$ Total ash - Total fly ash

(a) Wi 75, p. 398

(b) Wi $75, p .400$ 
TABLE 17. (contd)

Power Plant Waste Products (contd)

A Fly ash collected in scrubber = Total fly ash $x(0.997-0.900)$

$B$ Weight of $\mathrm{CaSO}_{4} \cdot 2 \mathrm{H}_{2} \mathrm{O}=\mathrm{Coal}$ consumption $\times \% \mathrm{~S} \times 0.9 \times 0.2 \times \frac{172}{32}$

C Weight of $\mathrm{CaSO}_{4} \cdot 1 / 2 \mathrm{H}_{2} \mathrm{O}=\mathrm{Coal}$ consumption $\times \% \mathrm{~S} \times 0.9 \times 0.8 \times \frac{129}{32}$

0 Weight excess reagents as $\mathrm{CaCO}_{3}=$

Coal consumption $\times \% 5 \times 0.9 \times \frac{100}{32} \times 0.2$

Total solids weight $=A+B+C+D$

Weight of water $=\frac{40}{60} \times$ Total solids weight

Total weight of sludge $=\frac{100}{60} \times$ Total solids weight

Bulk Density

Fly ash $=90 \mathrm{ft}^{3}$

Bottom ash $=80 \mathrm{ft}^{3}$

Dry FGD sludge $=80 \mathrm{ft}^{3}$

Atmospheric Emissions

$\mathrm{CO}_{2}=44 / 12$ Carbon content

$\mathrm{SO}_{2}=0.4$ lb per million Btu assuming a scrubber efficiency of $90 \%$. The emission standard is 1.2 lb per million Btu $(\operatorname{Max})(\mathrm{a})$

Particulates $=0.03$ lb per million Btu $($ Max $)(a)$

$N 0_{x}=0.6$ lb per million Btu (Max) for bituminous coal (a) 0.5 lb per million Btu (Max) for sub-bituminous coal(a)

(a) 40 CFR $60.42 \mathrm{a}$ 
Nuclear Fuel Cycle

The assumptions used in the nuclear scenarios are shown in Table 18.

In the United States, uranium is produced from underground and surface mines. The uranium content in the ore is $10 \mathrm{w}$, about $0.2 \%$ for underground and about $0.1 \%$ for surface. Uranium is also produced as a by-product of othea mining operations. The uranium is concentrated in mills located near the mi es. Mill tailings are ponded near the mill; some are returned to the mine as rackfill. Disposal practices must guard against excessive radon releases from mill tailings to nearby populations. Uranium imports are substantial in rela:ion to domestic production. In 1984, net imports were 60\% of United States production (DOE 85f, pp. 49, 77).

The mill concentrate, as ammonium diuranate, is transported by truc< or train to a conversion plant where it is converted into $\mathrm{UF}_{6}$. The $\mathrm{UF}_{6}$ is transported by truck or train to an enrichment $p l$ ant where the ${ }^{235} \mathrm{U}$ content is increased three-to-five fold. Depleted uranium tails are produced and sabred at the enrichment plant.

The enriched $U_{6}$ is transported by truck or train to a fuel fabricarion plant. There it is converted to $\mathrm{UO}_{2}$ and fabricated into fuel assemblies. The fuel assemblies are transported by truck to the reactor site.

After irradiation and cooling at the reactor site the fuel assembli $\div 5$ will be transported by train or truck to a national waste disposal site.

\section{TABLE 18. Nuclear Fuel Cycle Assumptions}

$\begin{array}{ll}\text { Ore Grade } & 0.14 \% 308 \mathrm{U} \\ \text { Mine Dilution } & 10.0 \% \\ \text { Milling Losses } & 10.0 \% \\ \text { Enrichment } & 3.5 \% 235 \mathrm{U} \\ \text { Tails Composition } & 0.25 \% 235 \mathrm{U} \\ \text { Fuel Exposure } & 37,500 \mathrm{MWd}(\mathrm{th}) / \text { metric ton } \\ \text { Capacity Factor } & 65 \%\end{array}$


COMPARISON OF THE COAL AND URANIUM FUEL CYCLES

The coal and uranium fuel cycle requirements and waste generation for producing 1 billion kWh of electricity are summarized in Table 19. One billion $k W h$ is roughly the electricity generation required annually by a city of 100,000. A 1000-MWe coal plant (two 500-MW units), operating at a $68 \%$ capacity factor, would consume each year six times the coal requirements shown in Table 19. The waste production correspondingly would be six times higher. Similarly, a 1000-Mwe nuclear plant would consume six times the fuel and produce six times the waste shown in Table 19. One PWR fuel assembly in reaching the reference exposure generates electricity equivalent to six 100-car trains (Figure 14).

ANNUAL FUEL CYCLE REQUIREMENTS AND WASTE GENERATION FOR THE COAL AND NUCLEAR SCENARIOS

In 1984, coal generated 1317 billion kwh and nuclear generated 324 billion kWh (NERC 85, p. 37). (a) The coal consumption in 1984 was 664 million tons (DOE 85d, p. 43).(b) Nuclear fuel consumption was about 1300 metric tons ( $U$ content in fuel assemblies) (DOE 85e, p. 63). For comparison, the actual consumption and waste generation in 1984 is compared with the projected consumption and waste generation in 2035 for the all coal and all nuclear scenarios (Table 20). The fuel consumption and waste generation for intermediate years for all three scenarios are shown in Appendix $G$. The fuel requirements and waste generation were determined using the assumptions shown in Tables 17 and 18 .

Under the all-coal scenario, coal consumption would increase about fourfold and reach 2.3 billion tons in 2035; nuclear fuel consumption would drop to

(a) Slight differences occur between NERC and EIA reported generation. EIA reports 1342 billion $\mathrm{kWh}$ for coal and 328 billion $\mathrm{kWh}$ for nuclear.

(b) The actual coal consumption in 1984 (664 million tons) was higher than would have been calculated using our long-range heat rate assumptions. We assumed $8500 \mathrm{Btu} / \mathrm{kWh}$, which applies to state-of-the-art steam plants. The average heat rate experienced in 1984 was $10,400 \mathrm{Btu} / \mathrm{kWh}$. Likewise, actual nuclear fuel consumption in 1984 was about 200 metric tons (U content in fuel assemblies) higher than would have been calculated since the average fuel exposure was about 20 percent less than the assumed fuel exposure. 
TABLE 19. Comparison of Typical Coal and Uranium Fuel Cycle Requirements and Impacts to Produce 1 Billion kWh of Electricity

\begin{tabular}{|c|c|c|}
\hline & Coal & Uranium \\
\hline Mining & 482,000 tons & 27,800 tons \\
\hline $\begin{array}{l}\text { Mine and Mill } \\
\text { Waste }\end{array}$ & 77,000 tons & $-27,800$ tons \\
\hline $\begin{array}{l}\text { Transportation } \\
\text { from Mine or } \\
\text { Mill }\end{array}$ & $\begin{array}{l}405,000 \text { tons } \\
4500 \text { coal cars }(90-\text { ton }) \\
45 \text { unit trains }(100-\text { car })\end{array}$ & $\begin{array}{l}35 \text { tons of ammonium diuranate in } \\
56 \text { drums }(50 \text { gal) } \\
1 \text { or } 2 \text { truckloads }\end{array}$ \\
\hline $\begin{array}{l}\text { Uranium } \\
\text { Conversion, } \\
\text { Enrichment, and } \\
\text { Fabrication }\end{array}$ & Not required & 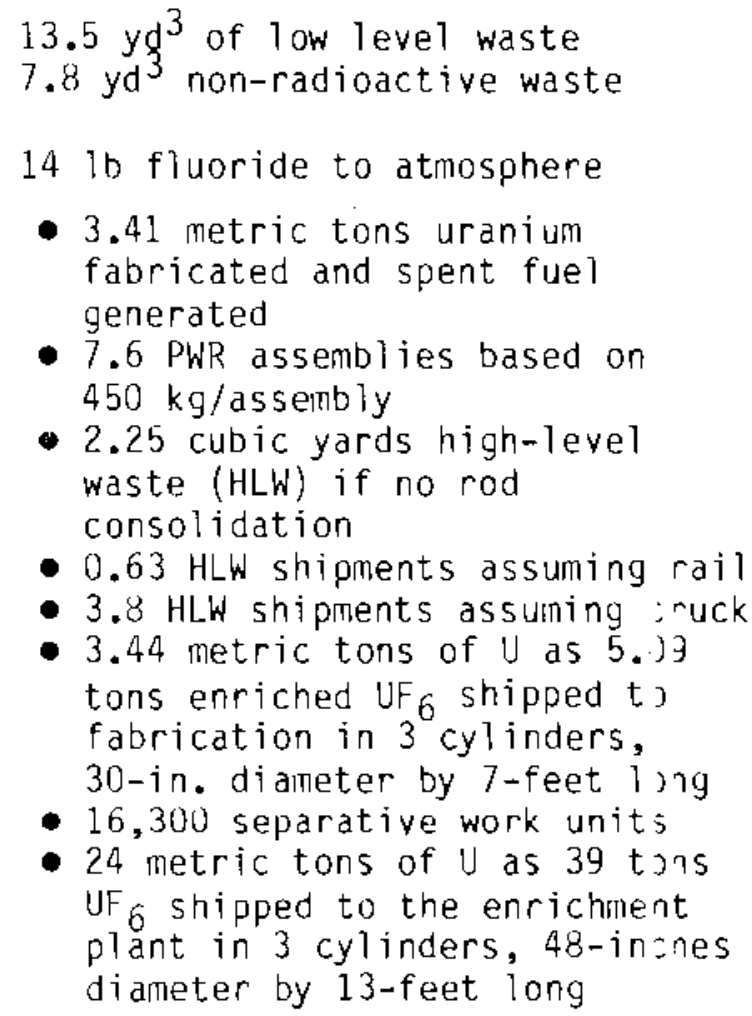 \\
\hline Electricity & $1,000,000,000 \mathrm{kWh}$ & $1,000,000,000 \mathrm{kwh}$ \\
\hline $\begin{array}{l}\text { Solid Wastes } \\
\text { from Power } \\
\text { Plant }\end{array}$ & $\begin{array}{l}40,000 \text { tons ash } \\
36,000 \text { tons dry sludge }\end{array}$ & $\begin{array}{l}7.6 \text { PWR fuel assemblies } \\
(\sim 6 \text { tons total assembly weight })\end{array}$ \\
\hline $\begin{array}{l}\text { Atmospheric } \\
\text { Emissions from } \\
\text { Power Plant }\end{array}$ & $\begin{array}{l}4,500,000 \text { ib } \mathrm{NO}_{\mathrm{x}}(\mathrm{a}) \\
250,000 \mathrm{lb} \\
\text { particulates }(\mathrm{a}) \\
10,000,000 \text { lb } \mathrm{SO}_{2}(\mathrm{a}) \\
1,300,000 \text { tons } \mathrm{CO}_{2}\end{array}$ & Negligible \\
\hline
\end{tabular}

(a) Regulatory limits, actual releases may be lower. 


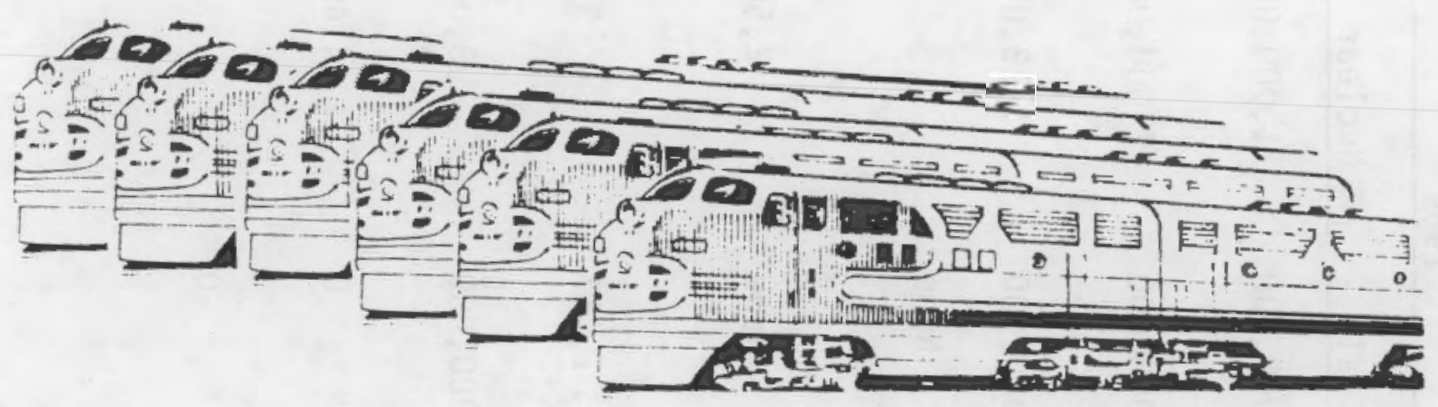

Six 100-Car Unit Trains

One PWR Fuel Assembly

FIGURE 14. Equivalent Electricity Generation 
TABLE 20. Fuel Cycle Requirements, Electricity Generation, and Waste Generation in 1984 and 2035

Mining

(tons mined)

Mine and Mill Waste

(cubic yards)

Mine Shipments (tons) $664,000,000$

Uranium Enrichment

(millions of separa-

tive work units)

Fuel Fabrication

(Equivalent number of

PWR fuel assembities)

Electrifity Generation
(TWh)

Non-Radioactive Waste $170,000,000$ (cubic yards)

Low Level Radioactive Waste (cubic yards)

High Level Radioactive Waste (cubic yards)

Gaseous Emissions

(thousands of tons)

$$
\begin{aligned}
& \mathrm{SO}_{2} \\
& \mathrm{NO}_{\mathrm{X}}{ }^{(\mathrm{b})} \\
& \mathrm{CO}_{2} \\
& \mathrm{~F}
\end{aligned}
$$$$
1,100
$$$$
3,400
$$$$
1,600,000
$$

0 1984

$\frac{\text { Coal }}{770,000,000} \frac{\text { Nuclear }}{11,000,000}$

None

$$
7,000,000
$$$$
370,000,000
$$$$
120,000,000
$$$$
13,000
$$$$
2,300,000,000
$$$$
6
$$

All Coal
Scenario

$2,800,000,000$ $160,000,000$$$
\text { None }
$$

2,500

0

44,000

1,317

324

5,782

5,782

3,000

$739,000,000$

45,000

0

4,400

0

78,000

0

700

0

13,000 
zero. The annual growth rate in coal consumption would increase gradually to $4 \%$ in 2015 and then decrease to $3 \%$ in 2035. At these low growth rates, no supply restrictions (a) should be encountered under existing regulations. However, there already is concern over the environmental impacts of existing coal plants. Increased coal combustion could exacerbate these impacts and lead to more stringent environmental control standards. More stringent standards, in turn, could result in lower fuel efficiency, which could lead to supply problems. The equivalent requirements and waste generation for other steps in both fuel cycles for the all coal scenario are summarized in Appendix $G$.

Under the all-nuclear scenario, coal consumption would drop to zero in 2035. Nuclear fuel requirements would increase to 20,000 metric tons uranium (as fuel elements) in 2035. The annual growth rate in nuclear fuel requirements would reach $7 \%$ per year in 2005 and drop to $3 \%$ in 2035 . The equivalent requirements and waste generation for other parts of both fuel cycles are sumarized in Appendix $G$ for the ail nuclear scenario.

Under the $50 \%$ coal $/ 50 \%$ nuclear scenario, coal consumption would increase to 1.4 billion tons and nuclear fuel requirements would increase to 10,000 metric tons $U$ in 2035. The coal consumption growth rate varies between 1 and $3 \%$ per year. The nuclear fuel requirements growth rate increases to $5 \%$ in 2005 then gradually decreases to $3 \%$ in 2035. The equivalent impacts on the other parts of both fuel cycles are summarized in Appendix $G$.

In order to compare the waste generation in more familiar terms, we converted the waste generation and resource requirements into per capita data (Table 21). Comparing the 1984 solid waste generation, coal plants produced about five garbage cans full of ash and sludge per person; nuclear plants produced less than one-quarter cup, most of which was radioactive. In 1984, coal produced about four times as much electricity as nuclear. The comparisons in 2035 are based on the all-coal and all-nuclear scenarios. In 2035, the

(a) Although coal could be phased-in to replace existing nuclear capacity over a number of years, an immediate shutdown in nuclear capacity and replacement with coal could cause severe econornic disruptions in at least five of the nine NERC regions (Table D.7). The reserve margins in these five regions would fall below 20\%. Nuclear generated between 20 and $32 \%$ of the electricity in these regions in 1985; this was estimated to have increased to 22 to $35 \%$ in 1986 . 
TABLE 21. Per Capita Waste Generation and Resource Requirements

\begin{tabular}{c}
1984 \\
Coal \\
\hline
\end{tabular}

Solid Waste

\begin{tabular}{|c|c|c|c|c|}
\hline Mine and Mill Waste & l cup & 4 teaspoonfuls & 4 cups & 1 cup \\
\hline Nonradioactive Waste & $\begin{array}{l}5 \text { garbage } \\
\text { cans }\end{array}$ & 2 teaspoonfuls & $\begin{array}{l}15 \text { garbage } \\
\text { cans }\end{array}$ & $1 / 2$ cup \\
\hline Low-Level Waste & None & 3 teaspoonfuls & None & $3 / 4$ cup \\
\hline $\begin{array}{l}\text { High-Level Waste } \\
\text { Gaseous Emissions }\end{array}$ & None & $1 / 2$ teaspoonful & None & 6 teaspoonfuls \\
\hline $\mathrm{CO}_{2}$ & 8 tons & None & 21 tons & None \\
\hline $\mathrm{SO}_{2}$ & $91 b$ & None & $291 \mathrm{~b}$ & None \\
\hline $\mathrm{No}_{x}(\mathrm{a})$ & $291 \mathrm{~b}$ & None & 9210 & None \\
\hline $\mathrm{F}$ & Negligible & 0.00003 ib & Negligible & $0.00041 b$ \\
\hline $\begin{array}{l}\text { Resource } \\
\text { Requirements }\end{array}$ & & & & \\
\hline $\begin{array}{l}\text { Ore Mined } \\
\text { Electricity } \\
\text { Generation }\end{array}$ & $6,000 \mathrm{lb}$ & $67 \mathrm{lb}$ & $17,0001 b$ & $1,0001 \mathrm{~b}$ \\
\hline $\begin{array}{l}\text { Kilowatt Hours } \\
\text { Produced }\end{array}$ & 5,500 & 1,400 & 18,000 & 18,000 \\
\hline
\end{tabular}

(a) Based on emission limits.

al1-coal scenario would produce about 15 garbage cans full of sludge and as! and 21 tons of gaseous emissions, mostly $\mathrm{CO}_{2}$; the all-nuclear scenario would produce about $2-1 / 2$ cups of waste of which one-eighth cup would be HLW. The population is assumed to grow from 237 million in 1984 to 321 million in 203; (Bureau of Census most 1ikely projection to 2025 , extrapolated to 2035 ). 


\section{CRITICAL RESOURCE REQUIREMENTS}

Under the all-coal scenario, 61 billion tons of coal, cumulative, would be required through 2035; this is $25 \%$ of the United States recoverable coal reserves of 245 billion tons (NCA 85). Under the 50\% coal scenario, 40 billion tons of coal are consumed, and under the all nuclear scenario, 19 billion tons of coal are consured. Much of the coal reserves in the West are on federal lands. These lands would have to be opened to leasing and mine development. Mine development is the critical path step in the expansion of coal production. However, low growth rates in the all-coal scenario coupled with the lead time for power plant construction should be sufficient for adequate mine development.

Under the all-nuclear scenario, 4 million tons of $\mathrm{U}_{3} 0_{8}$ would be required through 2035; this is $56 \%$ of the mean estimate of total United States recoverable $\mathrm{U}_{3} \mathrm{O}_{8}$ of $7.07 \mathrm{million}$ tons $(\mathrm{Pi} 81, \mathrm{P}$. $\mathrm{i} i$ ). It is estimated that 4 million tons of $U_{3} 0_{8}$ could be recovered at production costs under $\$ 100$ per pound $U_{3} 0_{8}$ ( $\mathrm{Pi} 81, \mathrm{p} .3 .4$ ). $\cup_{3} 0_{8}$ at $\$ 100$ per pound would increase generation costs by less than 1 -cent per $\mathrm{kWh}$ compared to current $U_{3} 0_{8}$ costs of $\$ 20$ to $\$ 30$ per pound.

Under the $50 \%$ nuclear scenario, 2.3 million tons of $U_{3} 0_{8}$ would be required through 2035--about $33 \%$ of the domestic recoverable $\mathrm{U}_{3} \mathrm{O}_{8}$. The costs for recovering 2.3 million tons of $U_{3} 0_{8}$ were estimated to be under $\$ 70$ per pound ( $P i 81$, p. 3.4). Under the all coal scenario only 0.66 million tons, $9 \%$ of the recoverable $\mathrm{U}_{3} \mathrm{O}_{y}$, is consumed.

Mine development is also a critical path step in the expansion of uranium production. The current capacity of United States uranium mines is unknown. Many mines have been shut down because of the depressed state of the industry. If all of the ore requirements in the all-nuclear and half-nuclear scenarios were met by domestic mines, United States uranium production would reach new peaks about 1997 under both scenarios (uranium ore production peaked at 17 million tons in 1980) (DOE 85f, p. 48). The amount of uranium imports, which is a major factor in the domestic supply, will determine the need for domestic mine development. The long lead times for power plant construction and the availability of imports should provide sufficient time for expanding ore production to meet the growing needs. 
Under the all-nuclear scenario, the United States capacity for separat ve work (currently 27 million separative work units) (DOE 85e, p. 40) is reached about 2005. At this time, new enrichment capacity or plutonium recycle wou ${ }^{-}$ be required to maintain the reference fuel exposure, assuming no imports of enrichment services. Under the half-nuclear scenario, the separative work capacity would be reached about 2015 .

The other parts of the nuclear and coal fuel cycles, except HLW disposal, are not as capital or energy intensive as enrichment. In addition, they require shorter lead times for capacity expansion than enrichment. These should present no supply constraints under the low growth rates resulting from the scenarios studied.

The federal government, through the nuclear waste policy act, is committed to providing nuclear waste repositories for HLW. Time tables have been established for spent fuel disposal that should not constrain nuclear power growth.

Reprocessing of spent nuclear fuels provides a potential alternative $=n$ expanding enrichment capacity and ore production. Reprocessing is capital intensive and requires a lengthy lead time. However, reprocessing is currently not included in fuel cycle planning; and, therefore, ldck of capacity will not constrain nuclear power growth under current plans.

Thus, save for enrichment capacity, no critical fuel cycle constraints should be encountered for the scenarios evaluated. 


\section{DISCUSSION AND CONCLUSIONS}

Growth in electricity demand has historically been closely linked to growth in GNP. For the first three-quarters of the twentieth century, a period of declining real electricity costs, the electricity demand grew faster than the growth in GNP. Since the 1973 oil embargo, real electricity costs have increased and the growth rate of electricity consumption has been approximately the same as that of the GNP.

During the next decade electricity demand is likely to increase at a slightly faster rate than real GNP growth because the real price of electricity is expected to decline over this period. There are several reasons for expected reductions in the real price of electricity:

- Energy supplies should remain abundant during most of the decade because of current over-capacity.

- Completion of new power plants will slow markedly, resultiı, in fewer additions to utility rate bases.

- Falling interest rates are pernitting refinancing of existing utility debt, thus lowering fixed charges.

- Current surplus capacity will be eliminated through growth, thus increasing the overall system capacity factor.

- The potential exists for increased competition between electricity suppliers in the future.

Over the longer term, the potential exists for continued reductions in the real price of electricity through technology improvements, continued low interest rates, construction cost decreases resulting from the utilization of standardized plants, shorter construction periods, and increased regulatory stability. If the real price of electricity declines, electricity demand will probably increase at a rate faster than that of the real GNP.

On the other hand, several factors could result in increasing prices of electricity and slower growth rates over the long-term. Some possibilities are: 
- Introduction of more stringent limits on emissions resulting from coal combustion has the potential for significantly increasing the costs of power generated by coal plants.

- Over-reliance on a single technology would decrease the competitive environment that now exists between technologies (e.g., coal and nuclear).

- Utilities could choose to use higher cost technologies for baseload capacity because of shorter lead times and reduced financial risks (e.g., gas turbines).

- Under-estimating growth in demand would cause increased utilization of higher cost, short lead time technologies.

Most forecasts of electricity demand project an average growth rate between 1.5 and $3.5 \%$ per year over the next three decades. Utility plans will result in a capacity expansion rate averaging $1.7 \%$ per year through 1994 . This is based on an assumed average annual growth rate of electricity demand of 2.3\%. This difference between the capacity expansion rate and the assumec growth rate in demand will be absorbed by current excess capacity, resultirg in a near-optimum reserve margin in the mid-1990s.

It is believed to be more likely that current utility planning will rusult in shortages in generation capacity in the mid-1990s rather than in surpluses. Growth projections currently used by utilities tend to be slightly lower than many forecasts. Current excess capacity is primarily a result of forecasts that were based on historical trends prior to 1973. Those projections for unrealized high growth rates resulted in commitments for excess capacity lufore recognition was made of the dramatic changes that were occurring in the market. Current growth rates used for planning new capacity additions ar: so low that, in the absence of negative growth rates in demand, significant unplanned increases in the reserve margin are highly unlikely.

Existing surplus generation capacity is expected to be absorbed by increased demand during the next ten years. At that time new plants will se required for the following five years at a "best estimate" annual rate of about $30 \mathrm{GW}$ per year. This is comparable to the 33 lW per year that was added 1uring 
the 1973-1977 time period and is significantly more than the planned addition of about $7 \mathrm{GW}$ per year during the 1991-1995 time frame.

It is important to recognize that, although the scenarios considered indicate a wide range in the need for new capacity in the 1996-2000 time frame (7) GW to $50 \mathrm{GW}$ per year), once the current surplus capacity no longer exists, 10-25 GW per year will be required to meet growth needs alone (excluding the need for replacement of obsolete capacity).

The requirements for replacement of obsolete capacity have a significant impact on the need for building new plants. The average age of the current installed capacity in the United States is now 24 years and is projected to reach 30 years in 1995. Through 1985, the average age of plants at retirement was 36 years and plants slated for retirement though the year 2000 will have an average age of 37 years. Depending on the average age at retirement, during the 1995-2005 time frame, somewhere between 10 and 250 GW of capacity will have to be replaced for 1 ifetimes ranging from 30 years to 50 years. Thus, the average annual requirement for replacement of obsolete capacity during that time frame will range from 1 GW to $25 \mathrm{GW}$.

The range of potential annual requirements for replacing old plants demonstrates the incentive for extending the lifetimes of these plants. This should give planners some sense of urgency of the need to pursue plant life extension efforts.

Based on current experience, only coal and nuclear technologies have the abundant indigenous resources and demonstrated capability to economically meet new growth requirements. In 1984, coal and nuclear plants generated $68 \%$ of the electricity; this is projected to increase to $76 \%$ in 1988 . Planned additional new baseload capacity during the next 10 years is about equally divided between coal and nuclear plants. For a number of decades beyond that time frame, sufficient indigenous resources exist such that either coal or nuclear technologies alone could meet growth requirements. However, because of concerns over each energy source and because of benefits associated with utilizing both technologies, an over-dependence on either should continue to be avoided. Significant concerns and benefits are summarized below. 
- The continuing fuel requirements and waste generation associated with coal plants are orders of magnitude greater than for nuclear plants. Nothing can change this. There are already concerns over the risks and environmental consequences of the existing level of coal usage. These concerns will probably limit future increases in coal usage. Research is needed to determine acceptable emission limits relevant to acid rain and possibly, in the future, to $\mathrm{CO}_{2}$ emissions. Also needed will be the technologies to meet future emission limits and handle the solid waste residues.

- Many concerns over the safety and economic viability of nuclear power have increased public opposition and eroded utility support. These concerns threaten the future of nuclear energy and will probably limit its rate of growth until many of these concerns are resoived. Measures are needed to reduce financial risk to utilities, simplify licensing, reduce reactor construction times and costs, resolve nuclear waste disposal concerns, and alleviate public concerns about nuclear safety.

- Reliance on a single technology would lead to a less competitive environment, probably resulting in higher electricity prices, A measure of the economic success of a particular nuclear power plant design is its ability to compete economically with coal plants.

- Although we have large domestic coal reserves, $25 \%$ of it will be consumed in the next 50 years if we were to rely exclusively on coal for new baseload capacity. It is probably not in the long-term national interest to deplete this resource at that rate. Large scalf. utilization of imported coal is not a viable option. However, utilization of large amounts of imported uranium is feasible. Compared tis coal, the transportation requirements are orders of magnitude lower. Additionally, nuclear power still holds the promise for extending domestic uranium reserves for several centuries through the? use of breeder reactors. 
All of the foregoing data point to the general conclusion that new base load plants must and will be constructed. It is in the best interest of the United States and the world to develop and apply the best technology to make maximum use of limited resources to meet future energy demands, notably electricity. Technology improvements and waste management practices obviously must be pursued and implemented to mitigate environmental impacts from electricity generation. Improvements in safety over the entire fuel cycle are always motivating factors and considerations in technology development and application. Additions in generating capacity and improvements in the quality of yenerating technology are not options but imperatives. 


\section{REFERENCES}

EW 85 "36th Annual Electric Utility Industry Forecast." Electrical World, September 1985.

NRC 86 Committee on Electricity in Economic Growth, Energy Engineering Board, Commission on Engineering and Technical Systems, National Research Council. 1986. Electricity in Economic Growth. National Academy Press, Washington, D.C.

Senate 85 Committee on Energy and Natural Resources. 1985. Hearings before the Committee on Energy and Natural Resources United States Senate Ninety-Ninth Congress. No. 53-859 0, U.S. Government Printing office, Washington, D.C.

D0E 85D Cornett, C. M. 1984. Analysis of Growth in Electricity Demand. 1980-1984. DOE/EIA-0476. Superintendent of Documents, U.S. Government Printing Office, Washington, D.C.

EPRI 78 Costs and Benefits of Over/Under Capacity in Electric Power System Planning. 1978. EPRI EA-927, Decision Focus, Incorporated, Palo Alto, California.

EPRI 86 Douglas, J. 1986. "The Value of Reliability." In the EPRI Journal. Vol. 11, Number 2.

EPRI 85 Electric Power Reserach institute (EPRI). 1985. NERC Summary Load Forecasts: A Retrospective Appraisal and Technical Analysis.

DOE 85 Energy Information Administration. 1985. Commercial Nuclear Power: Prospects for the United States and the World. DOE/EIA$0438(85)$, U.S. Governinent Printing Office, Washington, D.C.

DOE 85d Energy Information Administration. 1985. Electric Power Annual 1984. DOE/EIA-0348(84), U.S. Government Printing Office, Washington, D.C.

DOE $85 f$ Energy Information Administration. 1985. Uranium Industry Annual 1984. DOE/EIA-0478(84), U.S. Government Printing Office, Washington, 0.C.

DOE 85 e Energy Information Administration. 1985. World Nuclear Fuel Cycle Requirements 1985. DOE/EIA-0436(85), U.S. Government Printing office, Washington, D.C.

DOE 85a Energy Information Administration, Office of Coal, Nuclear, Electric, and Alternate Fuels. 1985. Annual Outlook for U.S. Electric Power 1985. DOE/EIA-0474(85), U.S. Government Printing Office, Washington, D.C. 
DOE 83 Energy Projections to the Year 2010. 1983. DOE/PE-0029/2. NTIS-PR360, National Technical Information Service, U.S. Department of Cominerce, Springfield, Virginia.

Fi 84 Finley, N. C., and N. H. Clark. 1984. Review and Evaluation of Literature on Coal and Nuclear Fuel Cycle Risk Comparisons. DE8 015124 , Sandia National Laboratories, Albuquerque, New Mexico.

Hy 85 Hyman, L. S. 1985. America's Electric Utilities: Past, Present, and Future. No. ISBN 0-910325-08-1. Public Utilities Reports, inc., Arlington, Virginia.

DOE 85C Inventory of Power Plants in the United States 1984. 1984. DOE/:IA0095(84), Superintendent of Documents, U.S. Government Printing office, Washington, D.C.

EPRI 84 Kurgan, G. J., J. M. Balestrino, and J. R. Daley. 1984. Coal Combustion By-products Utilization Manual - Volume 1. EPRI CS-3122, Electric Power Research Institute, Palo Alto, California.

NCA 85 National Coal Association. 1985-86 Facts About Coai. Washington, D.C.

NERC 85 North American Electric Reliability Council. 1985. Electric Pcwer Supply \& Demand for 1985-1994, October 1985.

Pi 81 Piepel, G. F., L. W. Long, R. A. McLaren, and C. E. Ford. 1981. Probabilistic Estimates of U.S. Uranium Supply. PNL-3595, Pacific Northwest Laboratory, Richland, Washington.

Se 85 Searl, M. F. 1985. Electricity and Economic Growth in the U.S. 1947-2000. Paper presented at the ANS Annual Meeting, June 11, 1985, Boston, Maine.

OTA 84 U.S. Congress, Office of Technology Assessment. 1984. Nuclear Power in an Age of Uncertainty. E OTA-E-216, Washington, D.C.

DOE 84 U.S. Department of Energy (DOE). 1984. "The Role of Nuclear Power," DOE/NE-0054. Washington, D.C.

ED 86 "Virginia Power Orders New Gas-Fired Plant." 1986. The Energy Daily. Vol. 14, No. 162.

Wi 75 Williams, Roy E. 1975. Waste Production and Disposal in Miniry, Milling, and Metallurgical Industries. ISBM 0-87931-035-3, Milton Freeran Publications, Inc.

NERC 86 North American Electric Reliability Council. 1986. Electricity Suply and Demand for 1986-1995, October 1986. 
APPENDIX A

PROJECTIONS OF ELECTRICITY DEMAND 
IABLE A.1. Projections of Electricity Demand

\begin{tabular}{|c|c|c|c|c|c|c|}
\hline Source & $\begin{array}{l}\text { Base } \\
\text { Year } \\
\end{array}$ & $\begin{array}{c}\text { Base Value, }(a) \\
\text { billions kwh }\end{array}$ & $\begin{array}{l}\text { Average } \\
\text { Annual } \\
\text { Growth } \\
\text { Rate, \% }\end{array}$ & $\begin{array}{l}\text { Fore- } \\
\text { Cast } \\
\text { Year } \\
\end{array}$ & $\begin{array}{l}\text { Forecast } \\
\text { Value, (a) } \\
\text { billions kWh }\end{array}$ & Reference \\
\hline DOE-EIA (High) & 1985 & 2492 & 3.8 & 1995 & 3618 & 1 \\
\hline DOE-EIA (LOW) & 1985 & 2492 & 2.7 & 1995 & 3252 & 2 \\
\hline DOE-EIA (Base) & 1985 & 2492 & 3.2 & 1995 & 3401 & 3 \\
\hline Siegel/Sillin & 1983 & 2310 & 4.5 & 2000 & 4881 & 4 \\
\hline DOE-EIA & 1983 & 2310 & 3.3 & 1995 & 3410 & 5 \\
\hline $\begin{array}{l}\text { Data } \\
\text { Resources, } \\
\text { Inc. }\end{array}$ & 1983 & 2310 & 3.1 & 2000 & 3881 & 6 \\
\hline DOE & 1982 & 2241 & 2.8 & 2000 & 3683 & 7 \\
\hline $\begin{array}{l}\text { Electrical } \\
\text { World }\end{array}$ & 1983 & 2310 & 2.8 & 2000 & 3693 & 8 \\
\hline $\begin{array}{l}\text { Dept. of } \\
\text { Commerce }\end{array}$ & 1983 & 2310 & 2.5 & 2000 & 3514 & 9 \\
\hline $\begin{array}{l}\text { Nt. l. Coal } \\
\text { Assoc. }\end{array}$ & 1982 & 2241 & 2.3 & 1995 & 3011 & 10 \\
\hline Wharton & 1983 & 2310 & 3.0 & 1994 & 3197 & 11 \\
\hline GRI & 1983 & 2310 & 2.4 & 2000 & 3457 & 12 \\
\hline Conoco, Inc. & 1982 & 2241 & 2.1 & 2000 & 3257 & 13 \\
\hline $\begin{array}{l}\text { R.W. Sant, } \\
\text { et al. }\end{array}$ & 1981 & 2286 & 1.5 & 2000 & 3078 & 14 \\
\hline $\begin{array}{l}\text { National } \\
\text { Audubon } \\
\text { Society }\end{array}$ & 1980 & 2286 & -0.8 & 2000 & 1946 & 15 \\
\hline
\end{tabular}

(a) All values converted to net generation. Net generation is assumed to be 9\% greater than end use consumption. 
TABLE A.1. (contd)

\begin{tabular}{|c|c|c|c|c|c|c|}
\hline Source & $\begin{array}{l}\text { Base } \\
\text { Year } \\
\end{array}$ & $\begin{array}{l}\text { Base Value, (a) } \\
\text { billions kwh }\end{array}$ & $\begin{array}{l}\text { Average } \\
\text { Annual } \\
\text { Growth } \\
\text { Rate, \% }\end{array}$ & $\begin{array}{l}\text { Fore- } \\
\text { Cast } \\
\text { Year } \\
\end{array}$ & $\begin{array}{l}\text { Forecast } \\
\text { value, (a) } \\
\text { billions kwh }\end{array}$ & Refererce \\
\hline NERC & 1983 & 2310 & 2.7 & 1993 & 3015 & 16 \\
\hline Chemical Bank & 1982 & 2241 & 2.9 & 2000 & 3749 & 17 \\
\hline NERC & 1984 & 2445 & 2.35 & 1994 & 3080 & 18 \\
\hline Wharton & 1984 & 2413 & 2.8 & 1994 & 3180 & 19 \\
\hline DRI & 1985 & 2499 (NERC) & 2.9 & 1995 & 3325 & 20 \\
\hline Koomanoff & 1983 & 2310 & 0.5 & 1990 & 2392 & 21 \\
\hline $\begin{array}{l}D D E-C P P A \\
\text { Scenario B }\end{array}$ & 1982 & 2241 & $\begin{array}{l}4.5 \\
3.2 \\
3.0 \\
2.8 \\
2.5\end{array}$ & $\begin{array}{l}1985 \\
1990 \\
1995 \\
2000 \\
2005\end{array}$ & $\begin{array}{l}2600 \\
2900 \\
3300 \\
3700 \\
4500\end{array}$ & 22 \\
\hline Scenario A & 1982 & 2241 & $\begin{array}{l}4.5 \\
2.9 \\
2.4 \\
2.2 \\
2.1 \\
1.9\end{array}$ & $\begin{array}{l}1985 \\
1990 \\
1995 \\
2000 \\
2005 \\
2010\end{array}$ & $\begin{array}{l}2600 \\
2800 \\
3100 \\
3300 \\
3600 \\
3800\end{array}$ & 23 \\
\hline Scenario C & 1982 & 2241 & $\begin{array}{l}4.5 \\
3.4 \\
3.1 \\
2.9 \\
2.7 \\
2.6\end{array}$ & $\begin{array}{l}1985 \\
1990 \\
1995 \\
2000 \\
2005 \\
2010\end{array}$ & $\begin{array}{l}2600 \\
2900 \\
3300 \\
3700 \\
4100 \\
4700\end{array}$ & 24 \\
\hline LOW GNP & 1982 & 2241 & $\begin{array}{l}2.6 \\
2.5 \\
2.0 \\
2.0 \\
2.0 \\
1.9\end{array}$ & $\begin{array}{l}1985 \\
1990 \\
1995 \\
2000 \\
2005 \\
2010\end{array}$ & $\begin{array}{l}2400 \\
2700 \\
2900 \\
3200 \\
3500 \\
3800\end{array}$ & 25 \\
\hline
\end{tabular}

(a) All values converted to net generation. Net generation is assumed to be $9 \%$ greater than end use consumption. 


\begin{tabular}{|c|c|c|c|c|c|c|}
\hline Source & $\begin{array}{l}\text { Base } \\
\text { Year } \\
\end{array}$ & $\begin{array}{c}\text { Base Value, }(\mathrm{a}) \\
\text { billions kwh }\end{array}$ & $\begin{array}{l}\text { Average } \\
\text { Annual } \\
\text { Growth } \\
\text { Rate, \% } \\
\end{array}$ & $\begin{array}{l}\text { Fore- } \\
\text { Cast } \\
\text { Year } \\
\end{array}$ & $\begin{array}{l}\text { Forecast } \\
\text { Value, } \\
\text { billions kwh }\end{array}$ & Reference \\
\hline High GNP & 1982 & 2241 & $\begin{array}{l}5.8 \\
4.5 \\
3.7 \\
3.4 \\
3.2 \\
3.0\end{array}$ & $\begin{array}{l}1985 \\
1990 \\
1995 \\
2005 \\
2015 \\
2010\end{array}$ & $\begin{array}{l}2700 \\
3200 \\
3600 \\
4100 \\
4600 \\
5200\end{array}$ & 26 \\
\hline $\begin{array}{l}\text { Roles } \\
\text { Reference } \\
\text { Cases }\end{array}$ & 1980 & 2286 & $\begin{array}{l}3.5 \\
3.0 \\
3.1\end{array}$ & $\begin{array}{l}1990 \\
2000 \\
2010\end{array}$ & $\begin{array}{l}3200 \\
4100 \\
5700\end{array}$ & 27 \\
\hline $\begin{array}{l}\text { Roles } \\
\text { (Enhanced) }\end{array}$ & 1980 & 2286 & 3.4 & 2010 & 6300 & 28 \\
\hline $0 i 1 \mathrm{Co} . \mathrm{A}$ & 1982 & 2241 & 3.1 & 2000 & 3800 & 29 \\
\hline $0 i 1 \mathrm{CO} . \mathrm{D}$ & 1982 & 2224 & 2.4 & 2000 & 3400 & 30 \\
\hline$A G A$ & 1982 & 2241 & 1.9 & 2000 & 3100 & 31 \\
\hline GR I & 1982 & 2241 & 2.7 & 2000 & 3600 & 32 \\
\hline DRI & 1982 & 2241 & 2.8 & 2000 & 3600 & 33 \\
\hline AES & 1982 & 2241 & 1.8 & 2000 & 3000 & 34 \\
\hline ORAU & 1982 & 2241 & 2.3 & 2000 & 3300 & 35 \\
\hline
\end{tabular}

(a) All values converted to net generation. Net generation is assumed to be 9\% greater than end use consumption.

Reference:

1-3 DOE, Energy Information Administration. "Annual Outlook for U.S. Electric Power 1985." D0E/EIA-0474 (85).

4-17 From William W. Hogan, "Energy Demand and the Outlook for Electricity." July 1985 in hearings before the Committee on Energy and Natural Resources, United States Senate, July 23 and 25, 1985. SHRG $99-253$.

15 The Audubon forecast assumed the adoption of certain energy conservation policies that did not occur. 
TABLE A.1. (Reference contd)

18 North American Electric Reliability Council. "1985 Electric Power Supply and Demand." Princeton, New Jersey.

19 Mark W. French. SHRG 99-253, p. 129.

20 Stephen A. Smith. SHRG 99-253, p. 148.

21 As reported in Siegel and Sillin, "Revitalizing Nuclear Power. The Case for Deregulation." Public Utilities Fortnightly, January 23, 1986.

22-26 DOE, Office of Policy, Planning and Analysis. "Energy Projections to the Year 2010" DOE PE-0029/2. October 1983.

27,28 D0E, Assistant Secretary for Nuclear Energy," The Role of Nuclear Power." DOE/NE-0054. July 1984.

29-35 Derived from data in DOE/PE-0029/2, p. 7-18. 
APPENDIX B

PROJECTIONS OF THE RATIO OF ELECTRICITY DEMANO GROWTH TO GNP GROWTH 
TABLE B.1. Projections of the Ratio of Electricity Demand Growth to GNP Growth

\begin{tabular}{|c|c|}
\hline Number & Source \\
\hline 1 & Siegel \\
\hline 2 & AEO \\
\hline 3 & Data Resources, Inc. \\
\hline 4 & $\mathrm{DOE}$ \\
\hline 5 & Electrical world \\
\hline 6 & Dept. of Commerce \\
\hline 7 & National Coal Assocication \\
\hline 8 & Wharton \\
\hline 9 & GRI \\
\hline 10 & Conoco, Inc. \\
\hline 11 & R.W. Sant \\
\hline 12 & National Audubon Society \\
\hline 13 & DRI \\
\hline 14 & Roles-Reference \\
\hline 15 & Roles-Enhanced \\
\hline 16 & $\begin{array}{l}\text { DOE-OPPA } \\
\text { Scenario B }\end{array}$ \\
\hline 17 & Scenario A \\
\hline 18 & Scenario $\mathrm{C}$ \\
\hline 19 & LOW GNP \\
\hline 20 & High GNP \\
\hline 21 & DOE-EIA (Middle) \\
\hline 22 & DOE-EIA (Middle) \\
\hline 23 & DOE-EIA (Middle) \\
\hline 24 & DOE-EIA（LOW） \\
\hline 25 & DOE-EIA (High) \\
\hline 26 & $011 \mathrm{Co} \cdot \mathrm{A}$ \\
\hline 27 & $0 i 1 \mathrm{Co} . \mathrm{B}$ \\
\hline 28 & $\mathrm{AGA}$ \\
\hline 29 & GRI \\
\hline 30 & DRI \\
\hline 31 & AES \\
\hline 32 & ORAU \\
\hline
\end{tabular}

\begin{tabular}{|c|c|}
\hline Period & Ratio \\
\hline $1983-2000$ & 1.29 \\
\hline $1983-1995$ & 1.14 \\
\hline $1983-2000$ & 1.07 \\
\hline $1982-2000$ & 1.00 \\
\hline $1983-2000$ & 0.97 \\
\hline $1983-2000$ & 0.93 \\
\hline $1982-1995$ & 0.92 \\
\hline $1983-1994$ & 0.91 \\
\hline $1983-2000$ & 0.86 \\
\hline $1982-2000$ & 0.75 \\
\hline $1980-2000$ & 0.58 \\
\hline $1980-2000$ & -0.32 \\
\hline $1985-1995$ & 1.00 \\
\hline $1980-2010$ & 1.15 \\
\hline $1980-2010$ & 1.13 \\
\hline $1982-2010$ & 0.96 \\
\hline $1982-2010$ & 0.79 \\
\hline $1982-2010$ & 1.04 \\
\hline $1982-2010$ & 0.87 \\
\hline $1982-2010$ & 1.06 \\
\hline $1985-1990$ & 1.10 \\
\hline $1991-1995$ & 1.35 \\
\hline $1985-1995$ & 1.19 \\
\hline $1985-1995$ & 1.35 \\
\hline $1985-1995$ & 1.12 \\
\hline $1982-2000$ & 1.11 \\
\hline $1982-2000$ & 1.00 \\
\hline $1982-2000$ & 0.66 \\
\hline $1982-2000$ & 1.04 \\
\hline $1982-2000$ & 1.00 \\
\hline $1982-2000$ & 0.69 \\
\hline $1982-2000$ & 0.79 \\
\hline Mean & $1.03^{\star}$ \\
\hline $\begin{array}{l}\text { Median } \\
\text { w/o DOE }\end{array}$ & $\begin{array}{l}1.00 \\
0.93 t\end{array}$ \\
\hline
\end{tabular}




\section{TABLE B.1. (contd)}

Notes:

1-12 Hogan op. cit., p. 96

13 Smith op. cit., p. 149

14-15 DOE, Assistant Secretary of Nuclear Energy, op. cit.

16-20 DOE, Office of Policy, Planning and Analysis, op. cit.

21-25 DOE, EIA - 0474 (85) op. cit.

26-32 Derived from DOE (PE-0029/2, Pp. 7-13 and 7-18)

* excluding Audubon projection

+ excluding all DoE projections 
APPENDIX C

COMPARISON OF EIA AND NERC CAPACITY AND

ELECTRICITY GENERATION INFORMATION 
TABLE C.1. Comparison of EIA and NERC Reported Capacity and Generation

1984

$\begin{array}{lr}\text { NERC - Summer Capability } & 604 \mathrm{GW} \\ \text { EIA - Nameplate Capacity } & 672 \mathrm{GW} \text { (Dec. 31) } \\ \text { NERC - Net Generation - U.S. } & 2,379 \text { Billion kWh } \\ \text { Net Imports } & 66 \mathrm{Billion} \mathrm{kWh} \\ \text { Net requirements for Load } & 2,446 \mathrm{Billion} \mathrm{kWh} \\ \text { EIA - Net Generation } & 2,413 \mathrm{Billion} \mathrm{kWh}\end{array}$

Al1 figures are for contiguous states. Sources: NERC 85 and DOE 85a. 

APPENDIX D

SUMMARY OF EXISTING U.S. POWER PLANTS 
TABLE D.1. Existing U.S. Power Plants, 1985

\begin{tabular}{|c|c|c|c|c|}
\hline Type & $\begin{array}{l}\text { Units } \\
\text { Number }\end{array}$ & Size Range, MW & $\begin{array}{c}\text { Total } \\
\text { Capacity, GW }\end{array}$ & $\begin{array}{c}\text { Average } \\
\text { Capacity, MW }\end{array}$ \\
\hline Steam & 2,660 & 0.5 to 1300 & 467.3 & 176 \\
\hline Hydro & 3,504 & 0.03 to 700 & 84.8 & 24 \\
\hline Nuclear & 91 & 50 to 1372 & 81.4 & 894 \\
\hline Gas Turbine & 1,378 & 0.8 to 206 & 47.7 & 35 \\
\hline Combined Cycie & 132 & 1 to 340 & 8.5 & 65 \\
\hline Internal Combustion & 3,093 & 0.02 to 42 & 5.2 & 2 \\
\hline Geotherma? & 23 & 3 to 140 & 1.7 & 72 \\
\hline Wind, solar & 23 & 0.01 to 12 & $<0.1$ & 1 \\
\hline TOTAL $(a)$ & 10,904 & 0.01 to 1372 & 695.5 & 64 \\
\hline
\end{tabular}

(a) Does not include 16 units with a total capacity of 5.7 GW that are completed but not yet in commercial operation.

Source: ElA data tape, February 1986.

TABLE 0.2. Inventory of Steam Power Units

$\begin{array}{cccccc}\text { Service Date } & \text { Number } & & \text { Size Range, Mw } & \begin{array}{c}\text { Total } \\ \text { Capacity, GW }\end{array} & \begin{array}{c}\text { Average } \\ \text { Capacity, MW }\end{array} \\ 1921-1920 & 20 & 1 \text { to } 35 & 1 \text { to } 160 & 0.2 & 12 \\ 1941-1950 & 176 & & 0.75 \text { to } 153 & 3.5 & 20 \\ 1951-1960 & 930 & 0.5 \text { to } 496 & 15.4 & 38 \\ 1961-1970 & 564 & 2.5 \text { to } 1150 & 90.0 & 97 \\ 1971-1980 & 403 & 126.5 & 224 \\ 1981-1985 & 102 & 0.8 \text { to } 1300 & 183.6 & 456 \\ \text { Unknown } & 62 & 2 \text { to } 90 & 46.3 & 454 \\ \text { T0TAL } & 2660(a) & 0.5 \text { to } 1300 & -1.7 & 467.3(a) & 176\end{array}$

(a) Does not include 2 units $(0.9 \mathrm{GW})$ which are completed but not in commercial operation.

Source: EIA data tape, February 1986. 
IABLE 0.3. Inventory of Nuclear Power Units

\begin{tabular}{|c|c|c|c|c|}
\hline Service Date & Number & Size Range, MW & $\begin{array}{c}\text { Tota? } \\
\text { Capacity, GW }\end{array}$ & $\begin{array}{c}\text { Average } \\
\text { Capacity, Mu }\end{array}$ \\
\hline-1970 & 11 & 75 to 860 & 5.9 & 536 \\
\hline $1971-1980$ & 58 & 50 to 1216 & 50.0 & 862 \\
\hline $1981-1985$ & $\underline{22}$ & 850 to 1372 & 25.4 & 1157 \\
\hline TOTAL & 91 & 50 to 1372 & 81.4 & 894 \\
\hline
\end{tabular}

Source: EIA data tape, February 1986.

TABLE 0.4. Inventory of Hydro Power Units

\begin{tabular}{|c|c|c|c|c|}
\hline Service Date & Number & Size Range, MW & $\begin{array}{c}\text { Total } \\
\text { Capacity, GW }\end{array}$ & $\begin{array}{c}\text { Average } \\
\text { Capacity, Mu }\end{array}$ \\
\hline-1920 & 892 & 0.04 to 24 & 2.6 & 3 \\
\hline $1921-1940$ & 994 & 0.05 to 83 & 7.5 & 8 \\
\hline $1941-1950$ & 286 & 0.06 to 129 & 5.3 & 18 \\
\hline $1951-1960$ & 455 & 0.1 to 90 & 14.7 & 32 \\
\hline $1961-1970$ & 450 & 0.1 to 204 & 24.5 & 54 \\
\hline $1971-1980$ & 219 & 0.2 to 700 & 23.6 & 108 \\
\hline $1981-1985$ & 208 & $\underline{0.03 \text { to } 351}$ & 6.8 & $\underline{33}$ \\
\hline TOTAL & 3504 & 0.03 to 700 & 84.9 & 24 \\
\hline
\end{tabular}

Source: EIA data tape, February 1986. 
TABLE D.5. Inventory of Gas Turbine Power Units

\begin{tabular}{|c|c|c|c|c|}
\hline Service Date & Number & Size Range, MW & $\begin{array}{c}\text { Total } \\
\text { Capacity, Gw }\end{array}$ & $\begin{array}{l}\text { Average } \\
\text { Capacity, MW }\end{array}$ \\
\hline-1960 & 11 & 1 to 12 & 0.1 & 6 \\
\hline $1961-1970$ & 602 & 0.8 to 146 & 14.1 & 23 \\
\hline $1971-1980$ & 739 & 0.8 to 206 & 32.0 & 43 \\
\hline $1981-1985$ & 25 & 1.5 to 170 & 1.6 & 65 \\
\hline Unknown & 1 & 20 & 30.0 & $\underline{0}$ \\
\hline TOTAL & 1378 & 0.8 to 206 & 47.7 & 35 \\
\hline
\end{tabular}

Source: EIA data tape, February 1986. 
TABLE D.6. Age of Existing Capacity

\begin{tabular}{|c|c|c|c|}
\hline Years & $\begin{array}{c}\text { Number } \\
\text { of }\end{array}$ & Capac & ity, GH \\
\hline of Startup & Units & Total & Cumulative \\
\hline-1900 & 33 & 0.03 & 0 \\
\hline $1901-1910$ & 310 & 0.6 & 1 \\
\hline $1911-1920$ & 574 & 2.2 & 3 \\
\hline $1921-1925$ & 462 & 2.4 & 5 \\
\hline $1926-1930$ & 414 & 3.7 & 9 \\
\hline $1931-1935$ & 195 & 1.7 & 11 \\
\hline $1936-1940$ & 441 & 3.5 & 14 \\
\hline $1941-1945$ & 353 & 6.7 & 21 \\
\hline $1946-1950$ & 933 & 14.6 & 35 \\
\hline $1951-1955$ & 1128 & 48.7 & 84 \\
\hline $1956-1960$ & 921 & 57.0 & 141 \\
\hline $1961-1965$ & 989 & 64.2 & 205 \\
\hline $1966-1970$ & 1525 & 109.2 & 315 \\
\hline $1971-1975$ & 1402 & 183.1 & 498 \\
\hline $1976-1980$ & 602 & 115.6 & 613 \\
\hline $1981-1985$ & 557 & 81.7 & 695 \\
\hline Unknown & 65 & 1.7 & 697 \\
\hline Testing & 18 & 6.9 & 703 \\
\hline Average Age & of Units: & 31 years & \\
\hline Average Age & of Capacity: & 24 years & \\
\hline
\end{tabular}


TABLE 0.7. Regional Nuclear Capacity and Generation (NERC 86, pp 26, A-2)

\begin{tabular}{|c|c|c|c|c|}
\hline Region & $\begin{array}{c}1985 \text { Nuclear } \\
\text { Capacity, } \\
\text { GW }\end{array}$ & $\begin{array}{c}\text { Total } \\
\text { Capacity, } \\
\% \\
\end{array}$ & $\begin{array}{c}\text { Total } \\
\text { Capacity, } \\
\text { Gw } \\
\end{array}$ & $\begin{array}{l}1985 \% \\
\text { Electricity } \\
\text { Generation } \\
\text { by Nuclear }\end{array}$ \\
\hline ECAR & 4.4 & 4.7 & 93.0 & 5.5 \\
\hline ERCOT & 0 & 0 & 43.8 & 0 \\
\hline MAAC & 9.4 & 19.9 & 47.2 & 25.6 \\
\hline MAIN & 9.9 & 22.2 & 44.6 & 31.7 \\
\hline MAPP & 3.7 & 12.9 & 28.7 & 19.5 \\
\hline NPCC & 7.9 & 15.4 & 51.3 & 23.2 \\
\hline SERC & 25.1 & 19.1 & 131.4 & 24.2 \\
\hline SPP & 3.8 & 6.1 & 62.2 & 8.4 \\
\hline WSCC & 6.9 & 5.8 & 119.4 & 7.2 \\
\hline U.S. Total & $71.3^{(b)}$ & 11.5 & $621.6(\mathrm{~b})$ & 15.1 \\
\hline
\end{tabular}

(a) Summer.

(b) Totals may not add due to rounding. 
- 
APPENOIX E

SUMMARY OF RETIRED POWER PLANTS 
IABLE E.1. Retired Capacity by Type through 1985

\begin{tabular}{|c|c|c|c|c|}
\hline Type & Number & $\begin{array}{c}\text { Total } \\
\text { Capacity, } 6 \text { W }\end{array}$ & $\begin{array}{c}\text { Average } \\
\text { Capacity, MW }\end{array}$ & $\begin{array}{l}\text { Average } \\
\text { Life, yrs } \\
\end{array}$ \\
\hline Steam & 759 & 19.2 & 25 & 38 \\
\hline Gas Turbine & 51 & 1.1 & 21 & 14 \\
\hline Nuclear & 6 & 1.0 & 161 & 21 \\
\hline $\begin{array}{l}\text { Internal } \\
\text { Combustion }\end{array}$ & 835 & 0.9 & 1 & 27 \\
\hline Combined cycle & 11 & 0.3 & 31 & 46 \\
\hline Hydro & 112 & 0.2 & 2 & 54 \\
\hline Wind Turbine & $\underline{2}$ & 0.0 & 2 & $\underline{4}$ \\
\hline TOTAL $(a)$ & 1776 & 22.7 & 12.8 & 36 \\
\hline
\end{tabular}

(a) Excludes 414 units $(5.3 \mathrm{GW})$ with unknown startup or retirement dates.

Note: Tables E.1 through E.4 were generated by the authors using an EIA data tape, dated February, 1986.

IABLEE.2. Retired Steam Capacity through 1985

\begin{tabular}{|c|c|c|c|c|}
\hline Type & Number & $\begin{array}{c}\text { Total } \\
\text { Capacity, GW }\end{array}$ & $\begin{array}{c}\text { Average } \\
\text { Capacity, MW }\end{array}$ & $\begin{array}{l}\text { Average } \\
\text { Life, yrs } \\
\end{array}$ \\
\hline Coat & 242 & 5.9 & 24 & 37 \\
\hline 011 & 235 & 8.0 & 34 & 39 \\
\hline Gas & 258 & 5.1 & 20 & 38 \\
\hline Other & 24 & 0.2 & 7 & 42 \\
\hline
\end{tabular}


TABLE E.3. Retirement by Year of Startup

\begin{tabular}{|c|c|c|c|c|c|}
\hline \multirow{2}{*}{$\begin{array}{l}\text { Startup } \\
\text { Period }\end{array}$} & \multirow{2}{*}{$\begin{array}{r}\text { Number } \\
\text { Retired } \\
\end{array}$} & \multirow{2}{*}{$\begin{array}{c}\text { Capacity } \\
\text { Retired, GW }\end{array}$} & \multirow{2}{*}{$\begin{array}{c}\text { Average } \\
\text { Capacity, MW }\end{array}$} & \multicolumn{2}{|c|}{ Cumulative } \\
\hline & & & & Retirement & Capacity \\
\hline $1900-1910$ & 21 & 0.05 & 2 & 21 & $0.1) j$ \\
\hline $1911-1920$ & 83 & 0.07 & 8 & 104 & $0.1) 7$ \\
\hline $1921-1930$ & 358 & 5.4 & 15 & 462 & $6 . ?$ \\
\hline $1931-1940$ & 331 & 3.1 & 9 & 793 & 9.3 \\
\hline $1941-1950$ & 626 & 7.4 & 12 & 1419 & 16. \\
\hline $1951-1960$ & 328 & 4.8 & 16 & 1747 & 21.2 \\
\hline $1961-1970$ & 200 & 2.1 & 11 & 1947 & $23 . t$ \\
\hline $1971-1980$ & 70 & 0.7 & 10 & 2017 & 24.3 \\
\hline $1981-1985$ & 10 & 0.1 & 9 & 2027 & 24.3 \\
\hline Unknown & 163 & 3.7 & 23 & $2190(a)$ & 28.0 \\
\hline
\end{tabular}

(a) Includes 27 units $(0.13 \mathrm{GW})$ sold to non-utilities, and not currently operating.

IABLE E.4. Retirement of Capacity by Time of Retirement

\begin{tabular}{|c|c|c|c|c|c|c|}
\hline $\begin{array}{c}\text { Retirement } \\
\text { Period }\end{array}$ & $\begin{array}{l}\text { Number } \\
\text { Retired }\end{array}$ & $\begin{array}{c}\text { Capacity } \\
\text { Retired, } \\
\quad \text { GW } \\
\end{array}$ & $\begin{array}{r}\text { Average } \\
\text { Capacity, } \\
\text { MW }\end{array}$ & $\frac{\text { Cumul }}{\text { Retirement }}$ & $\frac{\text { jue }}{\text { Capacity }}$ & $\begin{array}{l}\text { Avercie } \\
\text { Life, yr }\end{array}$ \\
\hline-1940 & 3 & 0.0 & 1 & 3 & 0.0 & 15 \\
\hline $1941-1960$ & 18 & 0.0 & 2 & 21 & 0.0 & 23 \\
\hline $1961-1970$ & 19 & 0.0 & 1 & 40 & 0.0 & 27 \\
\hline $1971-1975$ & 204 & 3.0 & 14 & 244 & 3.0 & 38 \\
\hline $1976-1980$ & 501 & 6.3 & 12 & 746 & 9.3 & 38 \\
\hline $1981-1985$ & 1031 & 13.5 & 13 & 1776 & 22.7 & 35 \\
\hline $1986-1990(a)$ & 245 & 5.9 & 24 & 2021 & 28.6 & 36 \\
\hline $1991-1995(a)$ & 154 & 8.3 & 54 & 2175 & 36.9 & 36 \\
\hline $1996-2000(a)$ & 41 & 3.2 & 78 & 2216 & 40.1 & 39 \\
\hline $2001-2010^{(a)}$ & 66 & 8.9 & 135 & 2282 & 48.9 & 38 \\
\hline
\end{tabular}

(a) Based on projections. 
APPENDIX F

SUMMARY OF PLANNED ADUITIONS 
TABLE F.1. Planned Increases in Installed Capability to 1994

Net Increase in Summer Capability Over 1984 (GW) Percent

Coal

50

47

Nuclear

50

47

Hydro

Geotherma ?

4

4

$0 i 1$

2

2

Gas

(2)

(2)

Dual Fuel

(2)

(2)

other

(2)

(2)

TOTAL $(a)$

9

8

107

100

(a) May not add due to rounding. Source: NERC 85, p. 17. 



\section{APPENOIX G}

ANNUAL WASTE GENERATION AND FUEL CYCLE REQUIREMENTS

IN SELECTED YEARS FOR THE THREE SCENARIOS 
TABLEG.1. Resource Requirements for Electricity Generation and waste Products for the Three Scenarios

\begin{tabular}{|c|c|c|c|c|c|c|}
\hline \multirow[b]{2}{*}{ Year } & \multicolumn{2}{|c|}{ All Coal Case } & \multicolumn{2}{|c|}{$50 / 50$ Case } & \multicolumn{2}{|c|}{ All Nuclear Case } \\
\hline & Coal & Nuclear & Coal & Nuclear & Coa1 & Nuclear \\
\hline 1984 & 1317 & 324 & 1317 & 324 & 1317 & 324 \\
\hline 1995 & 1568 & 586 & 1568 & 586 & 1568 & 586 \\
\hline 2005 & 2159 & 597 & 1725 & 1032 & 1290 & 1467 \\
\hline 2015 & 3135 & 393 & 1902 & 1627 & 668 & 2860 \\
\hline 2025 & 4335 & 182 & 2299 & 2218 & 262 & 4254 \\
\hline 2035 & 5782 & 0 & 2891 & 2891 & 0 & 5782 \\
\hline
\end{tabular}

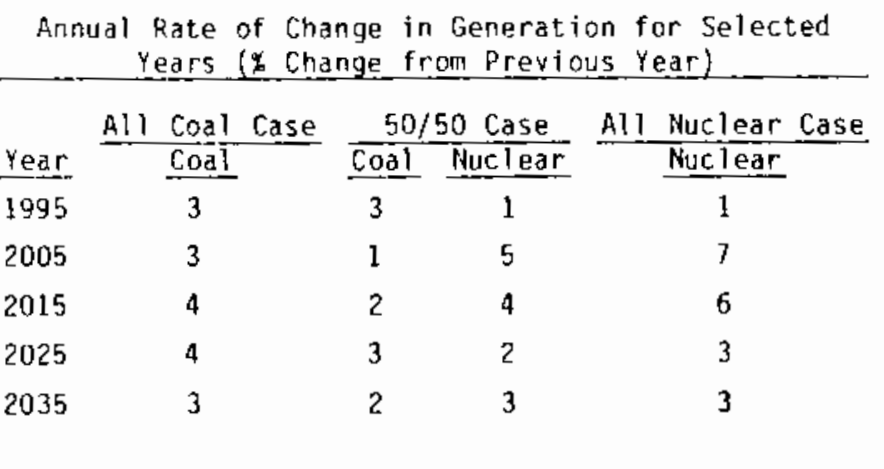

Millions of Tons of Coal or Ore Mined

Thousands of Cubic Yards of Nonradioactive Solids.

All Coal Case $50 / 50$ Case All Nuclear Case Year Coal Nuclear Coal Muclear Coa? Nuclear $1984635 \quad 9635 \quad 960635$ $\frac{\text { Year }}{1984} \frac{\frac{\text { All Cod Case }}{\text { Coal }}}{168356} \frac{\text { Nuclear }}{3}$ $50 / 50$ case

All Nuclear Case

$\begin{array}{rrrrrrr}1995 & 756 & 16 & 756 & 16 & 756 & 16 \\ 2005 & 1040 & 17 & 831 & 29 & 622 & 41 \\ 2015 & 1511 & 11 & 916 & 45 & 322 & 80 \\ 2025 & 2089 & 5 & 1108 & 62 & 126 & 118 \\ 2035 & 2786 & 0 & 1393 & 80 & 0 & 161\end{array}$

1984168356 Coal Nuclear Coal Nuclear

Thousands of Tons of Coal or Uranium Shipped

$\begin{array}{lllllll}1995 & 200442 & 5 & 200442 & 5 & 200442 & 5\end{array}$

$\begin{array}{lllllll}2005 & 275991 & 5 & 220512 & 8 & 164905 & 11\end{array}$

$\begin{array}{lllllll}2015 & 400756 & 3 & 243138 & 13 & 85392 & 22\end{array}$

$\begin{array}{lllllll}2025 & 554156 & 1 & 293888 & 17 & 33492 & 33\end{array}$

$\begin{array}{lllllll}2035 & 739130 & 0 & 369565 & 23 & 0 & 45\end{array}$

\begin{tabular}{|c|c|c|c|c|c|c|}
\hline \multirow[b]{2}{*}{ Year } & \multicolumn{2}{|c|}{ All Coal Case } & \multicolumn{2}{|c|}{$50 / 50$ Case } & \multicolumn{2}{|c|}{ All Nuclear Case } \\
\hline & coa1 & Nuclear & Coal & Nuclear & $\operatorname{coa} 1$ & Nuclear \\
\hline 1984 & 533072 & 11 & 533072 & 11 & 533072 & 11 \\
\hline 1995 & 634667 & 21 & 634667 & 21 & 634667 & 21 \\
\hline 2005 & 873881 & 21 & 598214 & 36 & 522143 & 51 \\
\hline 2015 & 1268929 & 14 & 769857 & 57 & 270381 & 100 \\
\hline 2025 & 1754643 & 6 & 930548 & 78 & 106048 & 149 \\
\hline 2035 & 2340334 & 0 & 1170167 & 101 & 0 & 202 \\
\hline
\end{tabular}

\begin{tabular}{|c|c|c|c|c|c|c|}
\hline \multirow[b]{2}{*}{ Year } & \multicolumn{2}{|c|}{ All Coal Case } & \multicolumn{2}{|c|}{$50 / 50$ Case } & \multicolumn{2}{|c|}{ All Nuclear Case } \\
\hline & Coal & Nuclear & Coal & Nuclear & Coal & Nuclear \\
\hline 1984 & 0 & 4374 & 0 & 4374 & 0 & 4374 \\
\hline 1995 & 0 & 7911 & 0 & 7911 & 0 & 7911 \\
\hline 2005 & 0 & 8060 & 0 & 13932 & 0 & 19805 \\
\hline 2015 & 0 & 5306 & 0 & 21965 & 0 & 38610 \\
\hline 2025 & 0 & 2457 & 0 & 29943 & 0 & 57429 \\
\hline 2035 & 0 & 0 & 0 & 39029 & 0 & 78057 \\
\hline
\end{tabular}


TABLE G.1. (contd)

Millions of Cubic Yards of Hine and Mill Haste

\begin{tabular}{|c|c|c|c|c|c|c|}
\hline \multirow[b]{2}{*}{ Year } & \multicolumn{2}{|c|}{ All Coal Case } & \multicolumn{2}{|c|}{ 50/50 Case } & \multicolumn{2}{|c|}{ All Nuclear Case } \\
\hline & Coal & tuclear & coal & Nuclear & Coal & Nuclear \\
\hline 1984 & 84 & 6 & 84 & 6 & 84 & 6 \\
\hline 1995 & 99 & 12 & 99 & 12 & 99 & 12 \\
\hline 2005 & 137 & 12 & 109 & 21 & 82 & 29 \\
\hline 2015 & 199 & 8 & $12 !$ & 33 & 42 & 57 \\
\hline 2025 & 275 & 4 & 146 & 44 & 17 & 85 \\
\hline 2035 & 367 & 0 & 183 & 58 & 0 & 116 \\
\hline
\end{tabular}

Number of 100 Car Coal Trains

\begin{tabular}{|c|c|c|c|c|c|c|}
\hline \multirow[b]{2}{*}{ Year } & \multicolumn{2}{|c|}{ All Coal Case } & \multicolumn{2}{|c|}{$50 / 50$} & \multicolumn{2}{|c|}{ Al! Nuclear Case } \\
\hline & Coal & Nuclear & Coal & Nuclear & Coa] & Nuclear \\
\hline 1984 & 30001 & 0 & 30001 & 0 & 30001 & 0 \\
\hline 1995 & 35719 & 0 & 35719 & 0 & 35719 & 0 \\
\hline 2005 & 49182 & 0 & 39296 & 0 & 29386 & 0 \\
\hline 2015 & 71415 & 0 & 43328 & 0 & 15217 & 0 \\
\hline 2025 & 98751 & 0 & 52371 & 0 & 5968 & 0 \\
\hline 2035 & 131714 & 0 & 65857 & 0 & 0 & 0 \\
\hline
\end{tabular}

_. Millions of Tons of Carbon Dioxide Released

All Coal Case $50 / 50$ Case All Nuclear Case Year Coal Nuclear coal Muclear Coal Muclear $19841564 \quad 0 \quad 1564 \quad 0 \quad 1564 \quad 0$ $\begin{array}{lllllll}1995 & 1862 & 0 & 1862 & 0 & 1862 & 0\end{array}$

$\begin{array}{lllllll}2005 & 2563 & 0 & 2048 & 0 & 1532 & 0\end{array}$

$\begin{array}{lllllll}2015 & 3722 & 0 & 2258 & 0 & 793 & 0\end{array}$

$\begin{array}{lllllll}2025 & 5147 & 0 & 2730 & 0 & 311 & 0\end{array}$

Cuvit Yards of ligh Level Radioactive Waste

\begin{tabular}{|c|c|c|c|c|c|c|}
\hline \multirow[b]{2}{*}{ Year } & \multicolumn{2}{|c|}{ All Coal Case } & \multicolumn{2}{|c|}{ 50/50 Case } & \multicolumn{2}{|c|}{ All Nuclear Case } \\
\hline & Coal & kuciear & Coâl & Nuclear & Coal & Nuciear \\
\hline 1984 & 0 & 729 & 0 & 729 & 0 & 729 \\
\hline 1995 & 0 & 1319 & 0 & 1319 & 0 & 1319 \\
\hline 2005 & 0 & 1343 & 0 & 2322 & 0 & 3301 \\
\hline 2015 & 0 & 884 & 0 & 3661 & 0 & 6435 \\
\hline 2025 & 0 & 410 & 0 & 4991 & 0 & 9572 \\
\hline 2035 & 0 & 0 & 0 & 6505 & 0 & 13010 \\
\hline
\end{tabular}

Militons of Separative Work Units for Uranium Enrichment

\begin{tabular}{|c|c|c|c|c|c|c|}
\hline \multirow[b]{2}{*}{ Year } & \multicolumn{2}{|c|}{ All Coal Case } & \multicolumn{2}{|c|}{ 50/50 Case } & \multicolumn{2}{|c|}{ All Nuclear Case } \\
\hline & Coal & Nuclear & Coal & Nuclear & Coal & Nuclear \\
\hline 1984 & 0 & 5 & 0 & 5 & 0 & 5 \\
\hline 1995 & 0 & 10 & 0 & 10 & 0 & 10 \\
\hline 2005 & 0 & 10 & 0 & 17 & 0 & 24 \\
\hline 2015 & 0 & 6 & 0 & 27 & 0 & 47 \\
\hline 2025 & 0 & 3 & 0 & 36 & 0 & 69 \\
\hline 2035 & 0 & 0 & 0 & 47 & 0 & 94 \\
\hline
\end{tabular}

Requirements* for Spent Fuel Shipments Assuming Rail (Multiply by Six for Truck)

All Coal Case 50/50 Case All Nuclear Case Year coal Nuclear Coal Muclear coal Muclear

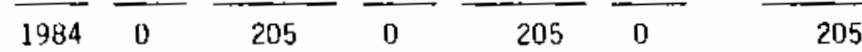
$\begin{array}{lllllll}1995 & 0 & 370 & 0 & 370 & 0 & 370\end{array}$ $\begin{array}{lllllll}2005 & 0 & 377 & 0 & 652 & 0 & 926\end{array}$ $\begin{array}{lllllll}2015 & 0 & 248 & 0 & 1027 & 0 & 1806\end{array}$ $\begin{array}{lllllll}2025 & 0 & 115 & 0 & 1401 & 0 & 2686\end{array}$ $\begin{array}{lllllll}2035 & 0 & 0 & 0 & 1826 & 0 & 3651\end{array}$ * Netive shiplitemls of spent tuel will not begin until a licensed facility becomes available. 
TABLE (i.1. (contd)

Thousands of Tons of Sulfur Oxides Released (Assuming 902 Recovery in Scrubbers)

\section{All Coal Case $50 / 50$ Case All Nuclear Case} Year coal Nuclear Coal Nuclear Coal Nuclear $\begin{array}{lllll}1984 & 1054 & 0 & 1054 & 0\end{array}$ $\begin{array}{llll}1995 & 1254 & 0 & 1254\end{array}$

$\begin{array}{lllll}2005 & 1727 & 0 & 1380 & 0\end{array}$

$2015 \quad 2508 \quad 0 \quad 1522 \quad 0$

$2025 \quad 3468 \quad 0 \quad 1839 \quad 0$

$2035 \quad 4626$

(1)

1054
1254
1032
534
210
0
Cumulative Generation (billions of kWh) from Coal Plus Nuclear Plants

\begin{tabular}{|c|c|c|c|c|c|c|}
\hline \multirow[b]{2}{*}{ Year } & \multicolumn{2}{|c|}{ All Coal Case } & \multicolumn{2}{|c|}{$50 / 50$ Case } & \multicolumn{2}{|c|}{ All Nuclear Case } \\
\hline & Coal & Nuclear & Cod & Nuclear & Coal & Niclear \\
\hline 1995 & 15239 & 5760 & 15239 & 5760 & 15239 & 5760 \\
\hline 2005 & 21003 & 6550 & 18271 & 9282 & 15539 & 12014 \\
\hline 2015 & 25330 & 5323 & 18132 & 13521 & 9934 & 21719 \\
\hline 2025 & 37597 & 2921 & 20883 & 19635 & 4169 & 36349 \\
\hline 2035 & 51500 & 367 & 26231 & 25636 & 962 & 50905 \\
\hline
\end{tabular}

Cumulative Consumption of Coal and 4308 in Milligns of Tons

All Coal Case 50/50 Case All Nuclear Case Year Coal Nuclear Coal Nuclear Coal Nuclear $\begin{array}{lllllll}1995 & 6168 & 0.18 & 6168 & 0.18 & 6168 & 0.18\end{array}$ $\begin{array}{lllllll}2005 & 14669 & 0.39 & 13564 & 0.47 & 12458 & 0.56\end{array}$ $\begin{array}{lllllll}2015 & 25327 & 0.55 & 20903 & 0.90 & 16479 & 1.24\end{array}$ $\begin{array}{lllllll}2025 & 40545 & 0.65 & 29355 & 1.51 & 18166 & 2.38\end{array}$ $\begin{array}{lllllll}2035 & 61390 & 0.66 & 39973 & 2.32 & 18556 & 3.98\end{array}$
Tons of Flouride Released To Air

All Coal Case 50/50 Case All Nuclear Case Year $\frac{\text { Coal }}{1984} \frac{\text { Nuclear }}{2} \frac{\overline{C o a}}{0} \frac{\text { Nuclear }}{2} \frac{\text { Coal }}{0} \frac{\text { Nuclear }}{2}$ 19840 19950 20050 20150 20250 20350

$\begin{array}{ll}2 & 0 \\ 4 & 0 \\ 4 & 0 \\ 3 & 0 \\ 1 & 0 \\ 0 & 0\end{array}$

40

4
$\begin{array}{lll}7 & 0 & 11\end{array}$ $\begin{array}{lll}12 & 0 & 21\end{array}$ $\begin{array}{llll}0 & 16 & 0 & 31\end{array}$

Thousands of Tons of Dxides of Nitrogen Released (Assuming Maximum Allowable Release)

\begin{tabular}{|c|c|c|c|c|c|c|}
\hline \multirow[b]{2}{*}{ Year } & \multicolumn{2}{|c|}{ All Coal Case } & \multicolumn{2}{|c|}{$50 / 50$ Case } & \multicolumn{2}{|c|}{ All Nuclear Case } \\
\hline & Coal & Nuclear & Coal & Nuc lear & Coal & Nuclear \\
\hline 1984 & 3358 & 0 & 3358 & 0 & 3358 & 0 \\
\hline 1995 & 3998 & 0 & 3998 & 0 & 3998 & 0 \\
\hline 2005 & 5505 & 0 & 4399 & 0 & 3290 & 0 \\
\hline 2015 & 7994 & 0 & 4850 & 0 & 1703 & 0 \\
\hline 2025 & 11054 & 0 & 5862 & 0 & 668 & 0 \\
\hline 2035 & 14744 & 0 & 7372 & 0 & 0 & 0 \\
\hline
\end{tabular}



APPENOIX H

NERC REGIONS 


\section{NORTH AMERICAN ELECTRIC RELIABILITY COUNCIL}

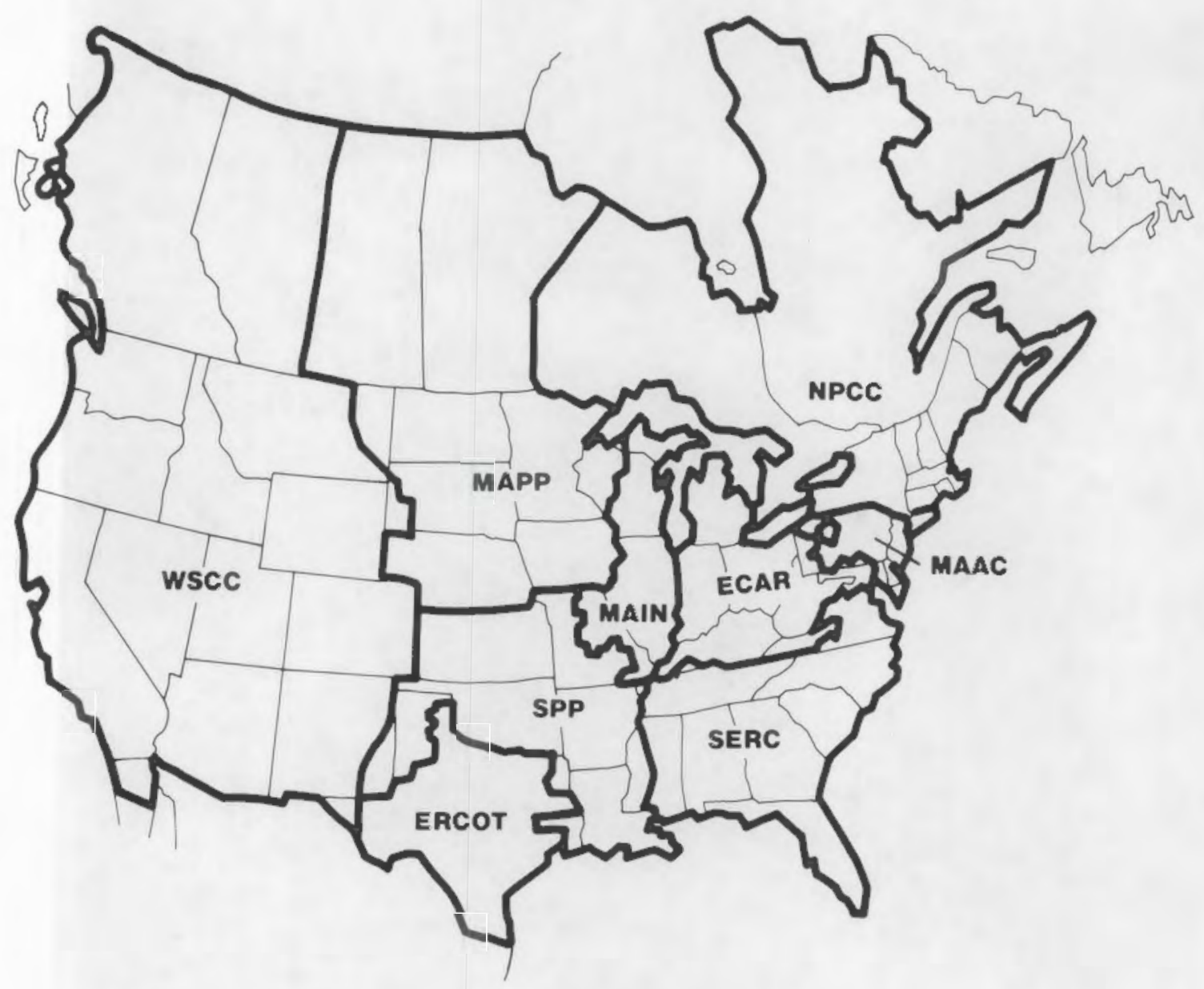

\section{ECAR}

East Central Area Reliability Coordination Agreement

\section{EACOT}

Electric Reliability Council of Texas

\section{MAMC}

Mid-Atlantic Area Council

MAIN

Mid-America Interconnected Network

\section{MAPP}

Mid-continent Area Power Pool

\section{NPCC}

Northeast Power Coordinating Council

\section{SERC}

Southeastern Electric Reliability Council

SPP

Southwest Power Pool

wsce

Western Sytems Coordinating Council 


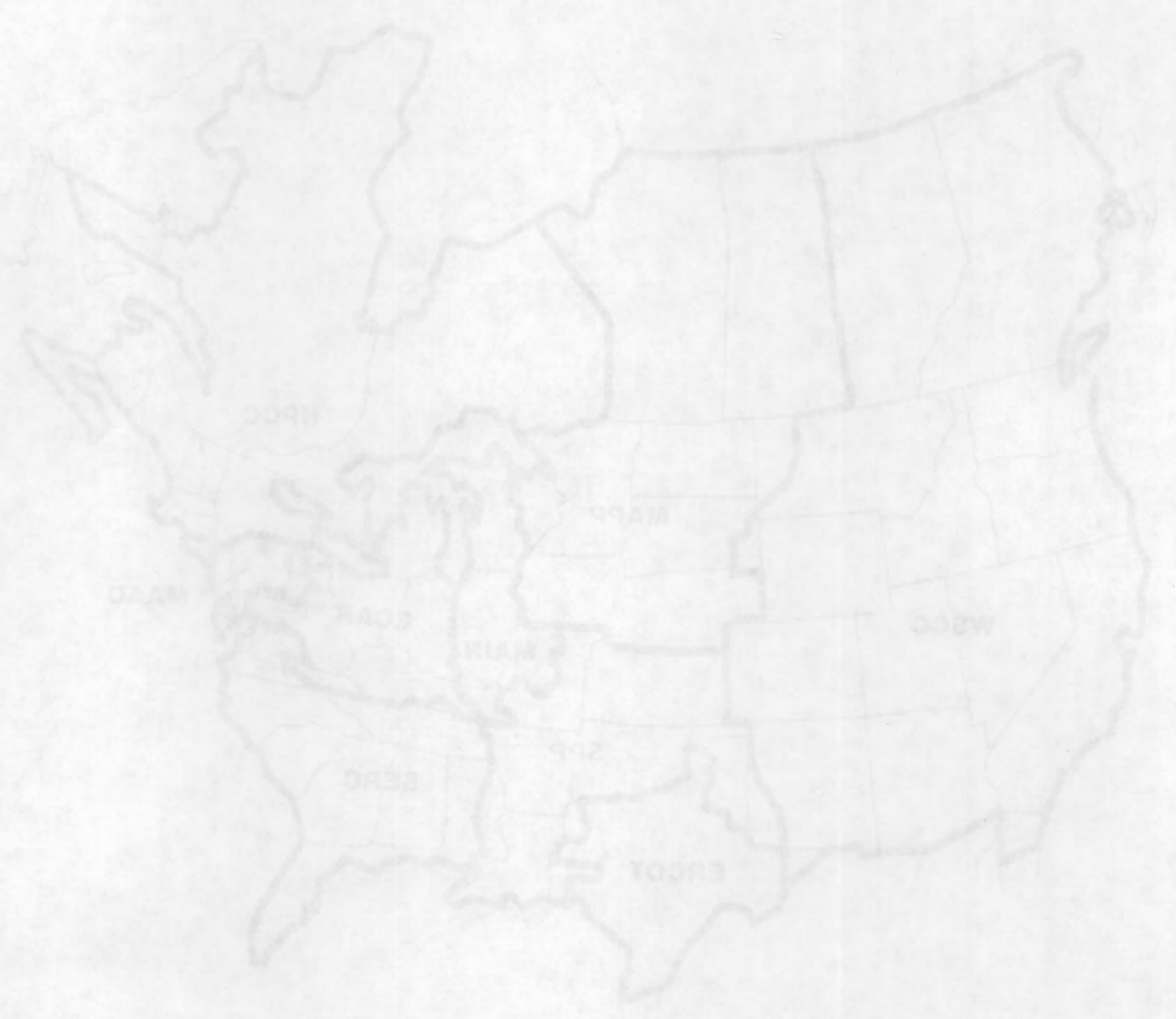




\section{APPENDIX I}

HISTORICAL OATA: INSTALLED CAPACITY AND NET CAPACITY ADDITIONS 
IABLE 1.1. Historical Data: Installed Capacity and Net Capacity Additions

\begin{tabular}{|c|c|c|c|c|c|}
\hline & $\begin{array}{l}\text { Installed } \\
\text { Nameplate } \\
\text { Capacity, GW } \\
\end{array}$ & $\begin{array}{c}\text { Net } \\
\text { Capacity } \\
\text { Addition, GW } \\
\end{array}$ & & $\begin{array}{c}\text { Installed } \\
\text { Nameplate } \\
\text { Capacity, GW }\end{array}$ & $\begin{array}{c}\text { Net } \\
\text { Capacity } \\
\text { Addition, GW }\end{array}$ \\
\hline 1926 & 23 & - & 1956 & 121 & 6 \\
\hline 1927 & 25 & 2 & 1957 & 129 & 8 \\
\hline 1928 & 28 & 3 & 1958 & 143 & 14 \\
\hline 1929 & 30 & 2 & 1959 & 157 & 14 \\
\hline 1930 & 32 & 2 & 1960 & 168 & 11 \\
\hline 1931 & 34 & 2 & 1961 & 181 & 13 \\
\hline 1932 & 34 & 0 & 1962 & 191 & 10 \\
\hline 1933 & 35 & 1 & 1963 & 211 & 20 \\
\hline 1934 & 34 & (1) & 1964 & 222 & 11 \\
\hline 1935 & 34 & 0 & 1965 & 236 & 14 \\
\hline 1936 & 35 & 1 & 1966 & 248 & 12 \\
\hline 1937 & 36 & 1 & 1967 & 269 & 21 \\
\hline 1938 & 38 & 2 & 1968 & 291 & 22 \\
\hline 1939 & 39 & 1 & 1969 & 313 & 22 \\
\hline 1940 & 40 & 1 & 1970 & 342 & 29 \\
\hline 1941 & 42 & 2 & 1971 & 369 & 27 \\
\hline 1942 & 45 & 3 & 1972 & 399 & 30 \\
\hline 1943 & 48 & 3 & 1973 & 442 & 43 \\
\hline 1944 & 49 & 1 & 1974 & 478 & 36 \\
\hline 1945 & 50 & 1 & 1975 & 508 & 30 \\
\hline 1946 & 50 & 0 & 1976 & 531 & 23 \\
\hline 1947 & 52 & 2 & 1977 & 560 & 29 \\
\hline 1948 & 57 & 5 & 1978 & 579 & 19 \\
\hline 1949 & 63 & 6 & 1979 & 598 & 19 \\
\hline 1950 & 69 & 6 & 1980 & 614 & 16 \\
\hline 1951 & 76 & 7 & 1981 & 635 & 21 \\
\hline 1952 & 82 & 6 & 1982 & 650 & 15 \\
\hline 1953 & 92 & 10 & 1983 & 658 & 8 \\
\hline 1954 & 103 & 11 & 1984 & 672 & 14 \\
\hline 1955 & 115 & 12 & & & \\
\hline
\end{tabular}



APPENDIX J

PROJECTIONS OF PEAK DEMANDS, CAPACITY, AND ANNUAL ADDITIONS FOR THE THREE SCENARIOS 
IABLE U.1. Projections (GW) for the High, Middle, and Low Demand Scenarios

\begin{tabular}{|c|c|c|c|c|c|c|c|c|c|}
\hline \multirow[b]{3}{*}{ YEAR } & \multicolumn{3}{|c|}{ Projected Peak Demand } & \multicolumn{3}{|c|}{ Projected Capacity } & \multicolumn{3}{|c|}{$\frac{\text { Annual Additions (a) }}{\text { Average Service }}$} \\
\hline & & owth Ra & & & erve Mar & ins & & & \\
\hline & $1.50 \%$ & $2.50 \%$ & $3.50 \%$ & $15.00 \%$ & $20.00 \%$ & $25.00 \%$ & 50 & 40 & 30 \\
\hline 1984 & 451 & 451 & 451 & 604 & 604 & 604 & & & \\
\hline 1985 & 458 & 462 & 467 & 611 & 617 & 617 & 7 & 13 & 23 \\
\hline 1986 & 465 & 474 & 483 & 517 & 639 & 639 & 7 & 22 & 28 \\
\hline 1987 & 472 & 486 & 500 & 628 & 655 & 655 & 11 & 18 & 24 \\
\hline 1988 & 479 & 498 & 518 & 639 & 664 & 664 & 13 & 13 & 22 \\
\hline 1989 & 486 & 510 & 536 & 647 & 672 & 672 & 9 & 14 & 21 \\
\hline 1990 & 493 & 523 & 555 & 655 & 676 & 593 & 9 & 9 & 31 \\
\hline 1991 & 501 & 536 & 574 & 659 & 587 & 717 & 7 & 17 & 36 \\
\hline 1992 & 508 & 550 & 594 & 664 & 694 & 743 & 7 & 13 & 34 \\
\hline 1993 & 516 & 563 & 615 & 668 & 704 & 769 & 7 & 19 & 43 \\
\hline 1994 & 524 & 578 & 636 & 672 & 712 & 795 & 5 & 17 & 38 \\
\hline 1995 & 531 & 592 & 659 & 674 & 720 & 823 & 3 & 19 & 40 \\
\hline 1996 & 539 & 607 & 682 & 676 & 728 & 852 & 2 & 14 & 39 \\
\hline 1997 & 547 & 622 & 706 & 681 & 746 & 882 & 7 & 26 & 49 \\
\hline 1998 & 556 & 637 & 730 & 687 & 765 & 913 & 9 & 31 & 50 \\
\hline 1999 & 564 & 653 & 756 & 690 & 784 & 945 & 9 & 32 & 52 \\
\hline 2000 & 573 & 670 & 782 & 694 & 804 & 978 & 9 & 30 & 59 \\
\hline 2001 & 581 & 686 & 810 & 699 & 824 & 1012 & 11 & 32 & 59 \\
\hline 2002 & 590 & 704 & 838 & 704 & 844 & 1048 & 11 & 30 & 62 \\
\hline 2003 & 599 & 721 & 867 & 708 & 865 & 1084 & 12 & 39 & 76 \\
\hline 2004 & 608 & 739 & 898 & 712 & 887 & 1122 & 14 & 32 & 70 \\
\hline 2005 & 617 & 758 & 929 & 716 & 909 & 1161 & 15 & 35 & 67 \\
\hline 2006 & 626 & 777 & 962 & 720 & 932 & 1202 & 10 & 33 & 61 \\
\hline 2007 & 635 & 796 & 995 & 731 & 955 & 1244 & 18 & 43 & 68 \\
\hline 2008 & 645 & 816 & 1030 & 742 & 979 & 1288 & 23 & 43 & 61 \\
\hline 2009 & 655 & 836 & 1066 & 753 & 1004 & 1333 & 24 & 44 & 62 \\
\hline 2010 & 664 & 857 & 1103 & 764 & 1029 & 1379 & 21 & 51 & 60 \\
\hline 2011 & 674 & 879 & 1142 & 776 & 1054 & 1428 & 23 & 50 & 67 \\
\hline
\end{tabular}

(a) Includes replacement of obsolete capacity based on service life assumptions. 
TABLE J.1. (contd)

Projected Peak Demand

\begin{tabular}{|c|c|c|c|c|c|c|c|c|c|}
\hline \multirow[b]{3}{*}{ YEAR } & \multicolumn{3}{|c|}{ Projected Peak Demand } & & \multicolumn{3}{|c|}{$\frac{\text { Annual Additions }\{a\rangle}{\text { Average Service }}$} \\
\hline & & owth Ra & & & erve Ma & & & & \\
\hline & $1.50 \%$ & $2.50 \%$ & $3.50 \%$ & $15.00 \%$ & $20.00 \%$ & $25.00 \%$ & 50 & 40 & 33 \\
\hline 2012 & 684 & 901 & 1182 & 787 & 1081 & 1478 & 21 & 53 & 64 \\
\hline 2013 & 695 & 923 & 1223 & 799 & 1108 & 1529 & 29 & 66 & 59 \\
\hline 2014 & 705 & 946 & 1266 & 811 & 1136 & 2583 & 23 & 59 & 66 \\
\hline 2015 & 716 & 970 & 1311 & 823 & 1164 & 1638 & 25 & 56 & 68 \\
\hline 2016 & 726 & 994 & 1356 & 835 & 1193 & 1696 & 23 & 50 & 79 \\
\hline 2017 & 737 & 1019 & 1404 & 848 & 1223 & 1755 & 32 & 56 & 75 \\
\hline 2018 & 748 & 1045 & 1453 & 861 & 1253 & 1816 & 32 & 48 & 71 \\
\hline 2019 & 760 & 1071 & 1504 & 874 & 1285 & 1880 & 33 & 49 & 72 \\
\hline 2020 & 771 & 1097 & 1557 & 887 & 1317 & 1946 & 39 & 46 & 87 \\
\hline 2021 & 783 & 1125 & 1611 & 900 & 1350 & 2014 & 38 & 52 & $9 ?$ \\
\hline 2022 & 794 & 1153 & 1667 & 914 & 1384 & 2084 & 40 & 48 & 96 \\
\hline 2023 & 806 & 1182 & 1726 & 927 & 1418 & 2157 & 53 & 42 & 99 \\
\hline 2024 & 818 & 1211 & 1786 & 941 & 1454 & 2233 & 46 & 48 & 102 \\
\hline 2025 & 831 & 1242 & 1849 & 955 & 1490 & 2311 & 42 & 49 & 106 \\
\hline 2026 & 843 & 1273 & 1913 & 970 & 1527 & 2392 & 35 & 59 & 110 \\
\hline 2027 & 856 & 1305 & 1980 & 984 & 1565 & 2476 & 41 & 54 & 114 \\
\hline 2028 & 869 & 1337 & 2050 & 999 & 1605 & 2562 & 32 & 49 & 118 \\
\hline 2029 & 882 & 1371 & 2121 & 1014 & 1645 & 2652 & 32 & 48 & 122 \\
\hline 2030 & 895 & 1405 & 2196 & 1029 & 1686 & 2745 & 29 & 45 & 126 \\
\hline 2031 & 908 & 1440 & 2273 & 1045 & 1728 & 2841 & 35 & 53 & 130 \\
\hline 2032 & 922 & 1476 & 2352 & 1060 & 1771 & 2940 & 29 & 50 & 135 \\
\hline 2033 & 936 & 1513 & 2434 & 1076 & 1815 & 3043 & 23 & 55 & 140 \\
\hline 2034 & 950 & 1551 & 2520 & 1092 & 1861 & 3150 & 29 & 53 & 144 \\
\hline 2035 & 964 & 1589 & 2608 & 1109 & 1907 & 3260 & 23 & 55 & 150 \\
\hline
\end{tabular}

(a) Includes replacement of obsolete capacity based on service life assumptions. 
PNL -6193

UC $-80,5$

DISTRIBUTION

No. of

Copies

OFFS ITE

50 E. F. Mastal

U.S. Department of Energy

Office of Nuclear Energy

19901 Germantown Road

Germantown, MD 20874

147 DOE Technical Information Center

David R. Nevius, Vice President North American Electric Reliability Council 101 College Road East

Princeton, NJ 08540-6601

U.S. Cominittee for Energy Awareness

P.0. Box 1537

Ridgely, MD 21681

\section{ONSITE}

DOE Richland Operations Office

J. J. Sutey
No. of

Copies

\section{Pacific Northwest Laboratory}

W. E. Bickford

C. H. Bloomster (20)

S. H. Bush

J. A. Christenson

T. T. Claudson

B. M. Cole

L. R. Dodd (10)

E. A. Eschbach

J. F. Fletcher

M. D. Frestiley

H. Harty

R. A. Libby

R. P. Marshall

J. P. McNeece

E. T. Merrill

R. E. Nightingale

L. T. Pedersen

A. W. Prichard

W. D. Richmond

W. B. Scott

B. D. Shipp

R. D. Widrig

Publishing Coordination (2)

Technical Report Files (5) 
